University of San Diego

Digital USD

1988

\title{
The Utilization of the Carl D. Perkins Vocational Education Act Funding within the Disabled Student Programs and Services (DSP\&S) of the California Community Colleges
}

Susan Jean Sargent EdD

University of San Diego

Follow this and additional works at: https://digital.sandiego.edu/dissertations

Part of the Leadership Studies Commons

\section{Digital USD Citation}

Sargent, Susan Jean EdD, "The Utilization of the Carl D. Perkins Vocational Education Act Funding within the Disabled Student Programs and Services (DSP\&S) of the California Community Colleges" (1988).

Dissertations. 529.

https://digital.sandiego.edu/dissertations/529

This Dissertation: Open Access is brought to you for free and open access by the Theses and Dissertations at Digital USD. It has been accepted for inclusion in Dissertations by an authorized administrator of Digital USD. For more information, please contact digital@sandiego.edu. 
THE UTILIZATION OF THE CARL D. PERKINS

VOCATIONAL EDUCATION ACT FUNDING WITHIN THE

DISABLED STUDENT PROGRAMS \& SERVICES (DSP\&S)

OF THE CALIFORNIA COMMUNITY COLLEGES

By

Susan Jean Sargent

A dissertation submitted in partial fulfillment

of the requirements for the degree of

Doctor of Education

University of San Diego

1988

Dissertation Committee

Susan M. Zgliczynski, Ph.D., Chair Emmett N. Casey, Ph.D.

Janet $R$. Writer, Ph.D. 


\section{ABSTRACT}

Federal legislation has had a profound impact upon the vocational education provided to students with disabilities. The Carl Perkins Vocational Education Act (VEA) of 1984 was designed to assure that vocational education programs were made available to all persons. Persons who are disabled were one of six populations targeted to receive specialized funding in order to assure their accessibility. The purposes of this study were: (a) to examine the distribution patterns of VEA funds within the California community college districts, (b) to identify services for students with disabilities funded by the VEA in each college, and (c) to identify the disability groups who received these services.

Survey research was the methodology that formed the basis of this study. Procedures for gathering this data included: (a) examination of the 1987-88 VEA budgets from all districts, (b) examination of Disabled Student Program and Services allocation reports for 1987-88, and (c) the development of a questionnaire.

The results indicated that California community colleges utilized the majority of VEA funds for the provision of supplemental and support services. These services included basic skills instruction, vocational guidance and counseling, mobility assistance, remedial courses, interpreter services, and tutor services. Limited 
funds were expended for the development of separate vocational programs. Students with physical disabilities. communication disabilities, and learning disabilities received the most services. Fewer services were available for students with acquired brain injuries, developmental disabilities, psychlatric disabilities, and substance abuse difficulties.

Recommendations resulting from this study were made at the federal, state, and local levels, noting the importance of federal funding and the implications for futher development. This study identified services and activities provided by VEA funds and emphasized the importance of further training of staft and the need for research on the evaluation of these services. 


\section{DEDICATION}

TO

My father

GEORGE EUGENE SARGENT

It is from this man that I developed an

appreciation for learning not only through academia

but through life's daily challenges and opportunities. 
I . INTRODUCTION........................ 1

Historical Development.................... 1

Purpose of the study.................. 7

The Importance of the study................ 9

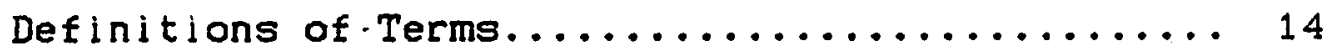

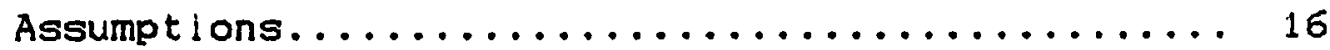

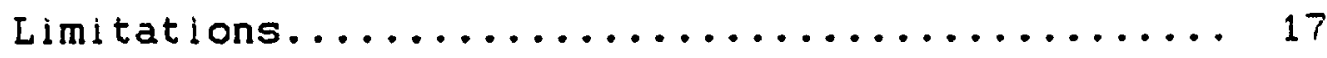

II . REVIEW OF LITERATURE................... 19

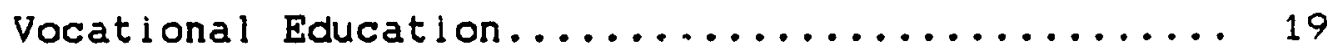

The Smith-Hughes VEA.................. 20

The $1930-1940$ Decade................... 21

The 1940-1950 Decade................... 22

The 1950-1960 Decade................... 24

The $1960-1970$ Decade.................... 25

The $1970-1980$ Decade................... 27

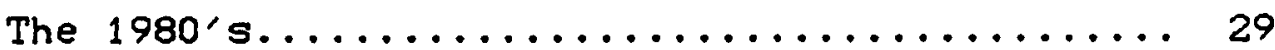

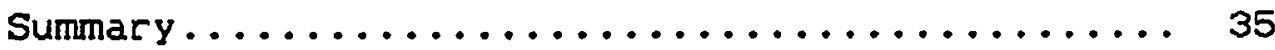

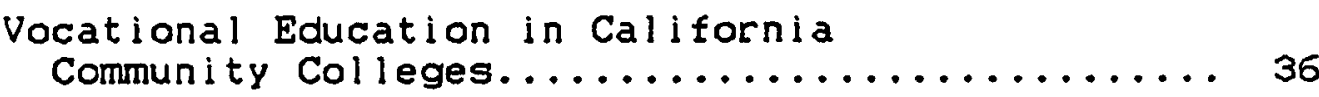

The Development of the Community College....... 36

Community Colleges Today................ 39

Students with Disabilities in the
Community Colleges.................... 41

Vocational Training for Students

with Disabilities................... 43

Barriers to Employment................ 44

Models of Employment Training............48 
Vocational Training for students with Disabilities

in the Community Colleges.................. 55

Summary........................... 57

II . METHODOLOGY......................... 60

Research Question Number $1 \ldots \ldots \ldots \ldots 60$

Research Question Number 2............. 61

Research Question Number $3 \ldots \ldots \ldots \ldots \ldots 2$

Research Design...................... 62

VEA Budget Reports...................63 63

DSP\&S 1987-88 Allocation Report...........6 63

The Questionnaire................... 63

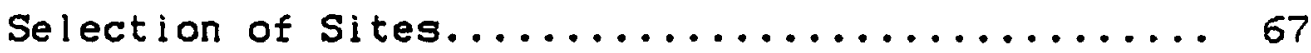

Districts........................... 67

Colleges............................. 68

Selection of Participants................ 68

Statistical Procedures.................. 69

Methods............................ 69

Dissemination .......................... 76

IV. ANALYSIS DE THE DATA................ 77

Introduction ..................... 77

Analysis of Budget Allocation Reports........ 77

Research Question Number $1 \ldots \ldots \ldots \ldots . \ldots . \ldots 77$

Analysis of the Questionniare............ 84

Research Question Number 2............. 84

Research Question Number $3 \ldots \ldots \ldots . \ldots . \ldots 7$

Conclusion......................... 102

Discussion of Findings................... 104 
V. CONCLUSIONS, IMPLICATIONS, AND RECOMMENDATIONS... 108

Conclusions.......................... 108

Impl lations......................... 111

Regular Vocational Education Programs....... 111

Special Vocational Programs.............113

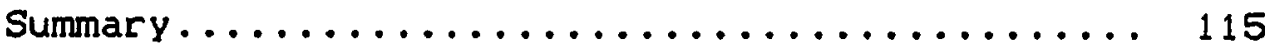

Application for VEA Funds................. 115

Excess Cost Factor................. 116

Staff Training and Development........... 117

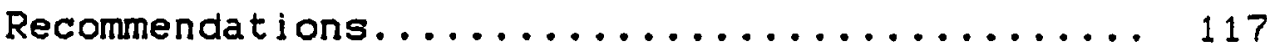

Recommendations at the Federal Level....... 117

Recommendations at the State Level........ 119

Recommendations at the Local Level......... 121

Recommendations for Further study.......... 122

REFERENCES............................. 124

APPENDICES. .......................... 144 


\section{LIST OF FIGURES}

FIGURES

Page

1. Allocations of Funds for Direct Costs........... 81

2. Allocations of Funds for Objects of Expenditures.. 83

3. The Percentages of Colleges Providing Services to Speclfle Disability Groups............... 88

4. Number of Students Served by VEA Funds Based Upon Disability Groups...................... 91

5. Comparison of Student Enrollment to the Number of Students Receiving Services under VEA......... 92 


\section{LIST OF TABLES}

\section{TABLE}

Page

1. The Relationship of VEA Handicapped Funds

to the Total VEA Budget.................. 78

2. The Relationship of VEA Handicapped Funds to DSP\&s Funding......................

3. Allocation of Objects of Expenditures by the

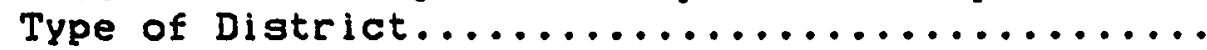

4. The Frequency and Percentage of Colleges Providing Services Across All Disability Groups.

5. The Allocation of VEA Funds by Colleges for Specific Services to Students with Disabilites...

6. Number of VEA Exemplary Programs and Projects....

7. Colleges Using Specific Service Delivery Models for VEA Supported Special Vocational Programs ...

8. The Numbers and Percentages of College Participants Who Received Training Related

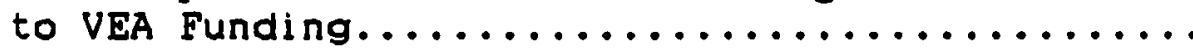

9. The Usefulness of VEA Related Training Received

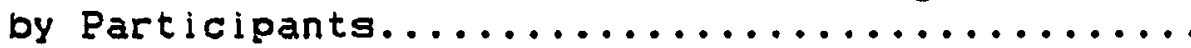

10. Areas of Training Needs As Reported by Participants........................... 100

11. Methods Participants Prefer for the Delivery of Training. 


\section{LIST OF APPENDICES}

$\begin{array}{ll}\text { APPENDIX Page } & \text { Pag }\end{array}$

A. Questionnaire........................... 144

B. Cover Letter for Questionnalre............... 151

C. Follow-Up Cover Letter..................... 154

D. Statistical Computations.................. 156 


\section{CHAPTER ONE \\ Introduction \\ Historical Development}

It is difficult to identify anything that has made a more profound impact upon the vocational education of" special needs students than the federal legislation enacted by Congress. The process of federal contributions, regulations, and influences did not appear, however overnight; it was a slow, evolving process that occurred over the history of our country (Bies, $1980, p .29$ ).

U.S. economic, political, and social life dictated the emergence of vocational education in the public schools. The Smith-Hughes Vocational Education Act of 1917, warranted as an emergency war measure during World War I, allocated federal funds to confront the harsh effects of the war years. Federal funds were provided for the promotion of vocational education in the schools for the first time in American history (Bies, 1980; Meers, 1980; Smith, 1979). Smith (1979) reported that vocational education met with turbulence and conflict from its beginning and not only remalned intact through the years but in most instances emerged with dignity. The first vocational education movement in the U.S. surfaced during WWI. Adult schools and training centers developed programs to train American 
workers to meet the demands of the war. The goal to produce war production workers directed the course of vocational training during WWI and WWII. By the end of WWII, 7.5 million people in the U.S. had been trained in response to the war efforts (Walters, 1986 ).

Many of the war training programs that began during WWII were replaced during the postwar years of $1945-1949$. Thousands of veterans returned home from the war requiring new skills for peacetime jobs. The G.I. Bill of Rights was enacted by Congress to provide extended education for veterans. Immediate enrollment of veterans occurred in retraining courses operated by junior colleges and adult vocational schools. Vocational education enrollments increased by 150 percent in the state of California alone.

During the $1950^{\prime} \mathrm{s}$ vocational education experiencea a decrease in activity. People who normally attended programs in vocational education were given Korean War assignments. A marked reduction in the need for specialized training in business and industry was evidenced across the nation and a succession of public inquiries as to the worth of the public schools occurred during this period. Ongoing programs were evaluatec and new curricula were planned and tested.

The Civil Rights Movement influenced the course of vocational education in the $1960^{\prime} s$ and the traditional concept of federally supported vocational education was revised in the amendments of the Vocational Education Act of 
1963 (Thornton, 1972). The VEA of 1963 allocated funas to provide vocational services to groups of people who had been previousiy excluded from programs. Persons who have academic, socioeconomic, or other handicaps that prevented them from succeeding in the regular vocational programs were written into the new Act (Smith, 1979). By 1968 the VEA was rewritten to provide specific funds for persons with disabilities.

The 1970's were eventful years in the eaucation of persons with disabilities due to the passages of monumentai legislation directed toward this population. Four major pieces of legislation were introduced which wouid aftect tine future of all persons with disabilities and their integration into society. These were:

1. Section 504 of the Rehabilitation Act of 1973: which prohibited discrimination based upon a handlcap. stating that "no otherwise qualified handicappea person, sinall, on the basis of handlcap, be excluded from particlpation in. be denled benefits of, or otherwise be subjected to discrimination under any program or activity that recelves or beneits from federal financial assistance" (Bies, 1980. ‥ 33):

2. the Education for All Handlcapped Chliaren Act of 1975 (PI 94-142): which mandated a free and appropriare education to all students with disabillties (Coliey, 1981); 
3. the 1976 Amendments of the VEA: which expanded resources to meet the needs of persons with disabilities by allocating $10 \%$ of the funds for program and services specifically for this population (Davis, 1980); and

4. the 1976 Lanterman Act: which funded programs for students with disabilities in California commity colleges (Expanding Educational Opportunities, 1986).

The impact of this legislation was that persons with disabilities could no longer be denied access to programs based upon their handicaps.

Vocational programs and services rapidly developed throughout California since the passages of the aforementioned pieces of legislation. Community colleges began serving the greatest number of students with disabilities seeking higher education. There were 48,772 students with disabilities enrolled in California community colleges in 1985 SExpanding Educational Opportunities, 1986). Phillips (1986) reported that the community colleges were in fact the greatest single provider of postsecondary education to students with disabilities. The majority of these students entered community colleges to increase their career options (Hartman, 1981). Many students with disabilities were drawn to community colleges because of available vocational training programs. Vocational programs expanded rapidly to meet. the growth demands of persons at the postsecondary level in the $1980^{\prime} \mathrm{s}$. The Vocational 
Education Act was amended in 1984 to meet these demands. This resulted in the Carl D. Perkins Vocational Education Act of 1984 which was designed to ensure that vocational education programs were accessible to all persons, including persons with disabilities.

The purposes of the Carl D. Perkins Vocational Education Act were: (a) to provide for vocational education services and activities designed to meet students with special needs; and (b) to enhance participation in vocational education programs through the improvement/ modernization, innovation (new programs) and expansion of these programs in order to meet the needs of the nation's existing and future work force CCarl D. Perkins Vocational Education Act, 1984). Little has been known regarding the effect of this act upon students with disabilities at the postsecondary level. A review of the literature proved I imited studies reporting services and programs funded for students with disabilities as a result of the Carl D. Perkins VEA.

The history of vocational education disclosed a dependence upon federal funding. A debate on whether or not federal funds continued to be needed for vocational programs began in the mid-1980's. Some educational leaders believed that state and local monies could provide sufficient funding (Shoemaker, 1987). Bottoms \& Copa (1983) noted that the economic base upon which most of the progress of vocational 
education has been built resulted directly from federal vocational education acts and amendments.

Federal funds have served through the years as a catalyst for innovation and change in vocational education. The loss of federal resources would bring damaging cutbacks in those activities that make it possible for vocational education programs to keep abreast of changing requirements in the workplace... The momentum toward providing educational equity would also suffer, because many of the activities that have brought progress in this area have been supported by federal funds (p. 351 ).

Guilinger (1987) believed that the key to maintalning and expanding services to students with disabilities were administrators who encouraged and supported innovative, quality programs. Bottoms \& Copa (1983) noted that leaders at all levels of government should have seriously considered the issues of funding. Data was critically needed (a) to provide governmental leaders with information on what services for persons with disabilities are threatened by federal cutbacks, and (b) to share this information with administrators who can contribute to the inception of new programs and the improvement of existing ones which until the expiration of the Carl D. Perkins VEA in 1989 are supported by federal funds. 


\section{Purpose of the Study}

The purposes of the study were: (a) to examine the distribution patterns of VEA funds within the community college districts, (b) to identjfy services for students with disabilities funded by the VEA in each college, and ( $c$ ) to identify the disability groups who received these services. Data was collected through the examination of records and the development of a questionnaire.

Fifty-seven district budget reports were utilized for this study, representing $81 \%$ of the California community college districts. Seventy-two college participants completed the questionnaire, representing $69 \%$ of the Cal ifornia community colleges.

The following research questlons were addressed.

Research Question Number 1: How were the VEA funds allocated within the Disabled Student Programs \& Services (DSP\&S) during 1987-1988?

The following three subsets responded to this question.

a. What percentage of the total VEA Title II-Part A, Basic Grants was allocated in each district to students with disabilities? 
b. What was the comparison of VEA funding for students with disabilities compared to funding allocated to each college for DSP\&S?

c. What was the distribution of VEA expenditures during 1987-88 for students with disabilities?

Research Question Number 2: What programs and services provided for student with disabilities in California community colleges were funded by the Perkins VEA?

The following five subsets responded to the second research question.

a. What activitles and services that meet the requirements of VEA funding were provided to students with disabilities?

b. What categories of disabilities received services through VEA funding?

c. What percentage of colleges received funding under VEA Special Projects for exemplary programs and special projects?

d. What models of employment were utilized in colleges that provided special vocational programs?

e. What was the composite of special vocational programs in colleges that identified model or exemplary programs? 
Research Question Number 3 : What areas of training did respondents receive regarding VEA funding and what areas of training did they identify as current needs?

Four subsets responded to this research question.

a. In what areas have DSP\&S staff received the most training?

b. How did the respondents perceive the usefulness of their training?

c. What areas of needs were identified by the respondents for training?

d. What delivery methods were identified as the means for potential training?

\section{The Importance of the study}

Vocational education programs clalmed high priority for students enrolled in community colleges (Smith, 1979). One of the originial functions of the community colleges was the establishment of vocational education courses to prepare students for employment. Vocational education in California community colleges included both academic certificate or degree programs and short-term job skills and retraining programs (Assembly Bill 1725, 1987). Programs in vocational education tripled during the past twenty years while 
enrollments in vocational agricultural have remained constant and classes for trade and industry, office occupations, health occupations and technical programs have drastically expanded (Bottoms \& Copa, 1983). While the role of the community colleges in the provision of vocational education had been established, too few services were extended to students with disabilities.

The literature reported that most adults with disabilities received little vocational or career education. Hof fman, Sheldon, Minskoff, Sautter, Steidle, Baker, Bailey and Echols (1987) conducted a needs analysis of students with learning disabilities and reported a lack of vocational education programs in community colleges. Kirchner, Simon and Stern (1985) revealed through a study on career information provided to students with visual impairments that only 20 percent of students felt satisfied with the amount of career information they received at a postsecondary level.

Only 36 percent of the 39,376 students enrolled in California community college reported that they received any specialized job placement assistance. Sixteen percent of colleges in California were found to provide job placement specific to students with disabilities, yet 100 percent of the students surveyed felt that they needed specialized services (Report to the Legislature, 1981). Piland \& Batsche (1985), in a study on coordinators of programs for 
students with disabilities in community colleges in Illinois, reported that little is known of services provided specific to adult students with disabilities for vocational purposes. The majority of coordinators indicated a desire to know more about existing vocational programs, as well as atyplcal services. In a similar study by Sampson (1984) of Cal ifornia community colleges data indicated that coordinators of programs have little awareness of the issues affecting career planning and placement for students with disabilities.

Federal legislation and funding have inspired educational programs to meet the needs of students of all disabilities, to integrate students of any age into community environments, and to promote vocational education in the high schools specific to the needs of students with disabilities. Schools have graduated students with more appropriate social, vocational, and independent living skills than previously. Most students and their families have gained higher expectations and goals as a result of this training. With many students moving out of institutions and others moving out of their family homes into more independent living arrangements, students with disabilities have demonstrated that, like other people, they can find their place in the outside world as productive citizens. 
While students with disabilities graduated with more training and skills, many of them continued to need support and additional training during their adult years (stodden \& Boone, 1987). Most of these students were faced with the problems of either a lack of services or extended waiting lists for available programs (McDonnell, Wilcox \& Boles, 1986). Many adults were forced to stay home where they often lost the work, living, and social skills they acquired in the outside world ( $\mathrm{Cel}$ is, 1987). Ongoing educationai support and assistance has proven fundamental to the endurance and malntenance of vocational, social, and living skills of adults with disabilities.

Individuals with disablities have faced many barriers to employment, including barriers which are not only physical but emotional and social as well. Mithaug (1979) revealed that employer attitudes have been reported as major obstacles for persons with disabilities seeking employment. "To overcome stereotypes, handicapped persons often must prove competence beyond a doubt, and so they need more education and credentials than others to compete for jobs" (Shworles \& Wang, 1983, p. 151). Entering the job market with necessary skills and work habits was reported often difficult for adults with disabilities who had to contena with societal attitudes as well as the additional pressures surrounding the work place. Continuing education provided additional support and preparation for adults to meet the 
demands of the working world and to gain the necessary skills for meeting these demands with greater success.

Community colleges had available resources necessary to offer specialized programs for students with unique needs. Carter (1986) explained: "Community college students of the 1980 s include adults, women, ethnic minorities, senior cltizens, the handicapped, foreign students, and high school graduates who are entering college for the first time. Institutions have assumed the implementation of special programs and services for students with specialized backgrounds" (p. 86). Literature documented the need and importance of ongoing vocational training and the participation of adults who are disabled in the work force.

This study examined existing vocational services and programs provided by community colleges funded under the Vocational Education Act. Information was shared with administrators at the Chancellor's Office of California Community Colleges and throughout the communtty colleges that could contribute to the improvement of vocational services and programs for persons with disabilities.

Federal funds had been a key factor in the development of supplemental services and vocational guidance and counseling for students with disabilities. This study identified the amount of services provided by community colleges through VEA funding. The threat of federal cutbacks was addressed and policy implications were made 
regarding the Disabled Student Frograms and Services (DSFES) role in the reauthorization of the current VEA.

\section{Definitions of Terms}

College specialist. A certificated employee hired by the community college specifically to plan, develop. coordinate and enable services and programs for handlcappea students (California Education Code, 1977).

Coordinator. The coordinator is defined as that Individual who has responsibility for the day-to-day operation of DSP\&S (Title 5, 1988).

Counselor. A counselor of DSP\&S shall de defined as a certificated counselor providing academlc, personal ana vocational guidance and counseling... The DSP\&S counseior shall be further authorized to instruct courses in guldance and counseling or college or lentation and to provide intake counseling assessments andior screenings for students enrolled in DSP\&S (Title 5, 1988).

Excess Cest Formula. This formula (a) takes the cost of a basic education program, (b) compares that figure to the cost of a given special education program, and then (c) applies funding to make up some or all of any discrepancy associated with excess costs of special education (Crowner, 1985, p. 505). 
Handicapped. Persons who are handicapped are defined as those individuals who have been evaluated appropriately as being mentally retarded, hard of hearing, deaf, speech impaired, visually handicapped, seriously emotionally disturbed, orthopedically impaired, other health impaired, deaf, blind, multi-handicapped, or as having specific learning disabilities, who because of those impairments need special education and related services (U.S. Federal Register, 1977, p. 42478).

Title II - Baslc Grants under the provisions of the Carl D. Perkins Vocational Education Act, 1984:

Part A - Opportunities. Provides for vocational

education services and activities designed to meet the special needs and enhanie the participation in vocational education programs of the following:

1. Handicapped individuals,

2. Disadvantaged individuals,

3. Adults who are in need of training and retraining,

4. Individuals who are single parents or homemakers,

5. Individuals who participate in programs designed to eliminate sex bias and stereotyping in vocational education,

6. Criminal offenders who are serving in correctional institutions. 


\section{Part B - Improvement. Innovation. Expansion.}

Provides for vocational education program improvement/ modernization, innovation (new programs) and expansion in order to meet the needs of the natlon's existing and future workforce. These funds cannot be used to maintain existing programs (Carl D. Perkins Vocational Education Act, 1984). Vocational Education. Organized educational programs whlch are directly related to the preparation of individuals in paid or unpald employment in such fields as agriculture, business occupations, home economics, health occupations, marketing and distributive occupations, technical and emerging occupations, modern industrial and agriculture arts, and trades and Industrial occupations, or for additional preparation for a career in such flelds, and in other occupations, requiring other than a baccalaureate or advanced degree and vocational student organization activities as an integral part of the program (Carl D. Perkins Vocational Education Act, 1984).

\section{Assumptions}

1. This study assumed that coordinators and college specialists of DSP\&S would provide accurate, honest answers.

2. Since this study was endorsed by the Chancellor's Office of Callfornia Community Colleges, it was 
assumed that the majority of DSP\&S coordinators and college specialists would participate in this study by completing the questionnaire and returning it promptly.

\section{Iumitations of the study}

1. Inherent limitations of the questionnaire included the possibility of an omission of responses, incorrect answers, and the complete lack of a response. Three colleges were withdrawn from this study due to an inconsistency in response and or an omission of responses. This study received endorsement from the Chancellor's Office and requested descriptive factual information, both of which minimized these occurrences.

2. While endorsement from the Chancellor's Office was an advantage, it might have ceen a limitation. Since the results of the study were submitted to the Chancellor's Office, respondents may have been particulary careful in filling out the questionnaire. The possibility exists that some respondents may have been reluctant to answer truthfully. However, it is an assumption that since the respondents were highly educated and committed to their work, they were honest in their responses.

3. Thls study requested information from DSP\&S personnel who were coordinators, college specialists or counselors. These positions required different job tasks 
and responsibilities. Some staff had more responsibility and experience with vocational training than others. While this may be a limitation, the questions requested in this study dealt with factual information on programs and services rather than opinions and attitudes toward these programs and services. Therefore this study should not have been effected by these differences. 


\section{CHAPTER TWO \\ Review of Literature \\ Vecational Education}

A review of the literature on the history of vocational education disclosed a field of education that depended heavily upon federal funding and legislation. Shoemaker (1987) reported that federal funds stimulated the growth of vocational services to youth and adults throughout the country. "From the Smith-Hughes Act of 1917 to the lanamark Vocational Education Act of 1963, federal funding led the way to the development of a system of vocational education in every state, with the emphasis on economic goals" (Shoemaker, 1987, p. 34).

Sathre (1987) suggested that it is easier to understand where we are going if we know where we came from. Bottoms \& Copa (1983) noted that it is critical to understand the economic base upon which the progress of vocational education has been built. While limited research existed on the history of vocational education, several prominent researchers have provided a systematic evaluation of the past. Smith (1979) traced the history of vocational education in California from 1900 to 1975; Barlow (1967) examined the history of Industrial education in the United States from 1870 to 1965; and Roberts (1971) evaluated the 
history, development, and principles of vocational and practical arts education.

Following is a summary of the development of vocational education, as portrayed by these researchers. The history began with the passage of the Smith-Hughes Vocational Education Act through the decades 1930-1940, 1940-1950, $1950-1960,1960-1970,1970-1980$, and into the more current years of the 1980 's. The Smith-Huahes Vocational Education Act

The Smith-Hughes Vocational Education Act (VEA) was not only the first legislation authorizing federal aid to the public schools but the first time Congress designated acceptance of vocational education in the schools. This Act declared an intent to promote vocational education and all operations of the act emphasized future employment of American workers (Smith, 1979). Bailey and Stadt (1973) described the four major purposes of the act, which were:

1. the promotion of vocational education.

2. cooperation with the states in the promotion of education in agriculture, trades and industries,

3. cooperation with the states in the preparation of vocational teachers,

4. regulation of funding for these activities. In addition, the Act required that the states designate a state board for vocational education and submit a plan to carry out the purposes of this Act. 
The initial arrangements of the Act were made in 1918-1919 and developed between 1920-1930 when teacher programs were instituted and programs trained American workers to meet the demands of the war. Smith (1979) explained that it was during these years that vocational education was transformed into a reality. The training and retraining of youths and adults during the war and the postwar years established vocational education in the American educational system. Within this ten year period. enrollments into vocational education programs increased sevenfold, a strong commitment was established in the community colleges for the vocational training of adults, professional associations in vocational education emerged, and teacher education programs were developed. Vocational education programs were well established to meet an unstable economy by the end of the Great Depression. The $1930-1940$ Decade

Smith (1979) noted that the depression which coincided with the start of the decade created divergent influences in vocational education. On the one hand, recommendations were made to reduce expenditures for all of education. On the other hand, pressures existed for new vocational education services to meet the needs of laid-off and unemployed workers. Considerable attention was given to the problems of the Depression cutbacks: Concerns over curriculum mounted and critics questioned what types of education were 
of utmost worth. The State Department of Education began efforts to promote vocational education and advocated vocational education as a critical unit necessary to meet the economic difficulties of the nation. The first vocational agricultural education program was established at the California Polytechnical School in 1931. This school was the beginning of essential Institutions for vocationai education. Smith (1979) reported that it was the first institution to establish respect to the field of vocational education .

The $1940-1950$ Decade

Vocational education was forced to meet with even harsher demands during World War II and the postwar years. Barlow (1967) and Smith (1979) explained that WWII influenced the training of workers and by the end of the war, $7.5 \mathrm{milli}$ ion people in the U.S. were trained in response to the war effort. Two major pieces of legislation were instituted to confront the war: (a) the War Production Training Act; and (b) the Rural War Production Training Act. The passage of the War Production Act provided federal aid for immediate training in shipbuilding, aircraft manufacturing, repair and machine shop occupations. Complicated by a farm labor shortage and the nation's neea to produce food and fiber, the Rural War Production Training Act was developed to provide emergency funds and training of agricultural workers. Programs would deal with food 
conservation, and the training of farm workers, the repair and operation of farm equipment and agricultural production. The responsibilities brought on by the war caused public schools to recognize vocational education programs as a continulty of national defense and develop programs to emphasize training suitable for immediate employment. This facilitated new apprentlceship programs, preparation of vocational agricultural teachers and the concept of work experience education (Smith, 1979, Walters, 1986).

Smith (1979) described the postwar years as a period of confusion, indecision, and frustration. Christian \& Steele (1982) reported that vocational education survived the war years to $f$ ind itself flooded with workers no longer able to utilize their skills and a need to phase out war training programs . The private sector of employment would need a higher-skilled work force and in anticipation of this need, a State Commission on Reconstruction and Development was created. The task of this commission was the implementation of the G.I. Bill of Rights and the retraining of the American worker. The Commission for Vocational Education launched a vigorous push to promote vocational education in every junior college. The Commission enacted plans to upgrade programs and organize new curriculum and the federal government provided funds to establish programs for veterans and displaced workers (Smith, 1979). Thousands of veterans 
enrolled in courses operated by junior colleges and vocational schools around the country (Lannie, 1971). Thornton (1972) found that growing acceptance of vocational programs continued until the $1950^{\prime} \mathrm{s}$ and was evident in a substantlal increase of enroliments in programs. The 1950-1960 Decade

As fast as the pace increased from 1945 to 1950 , the drop was almost as dramatic in the early 1950's. Vocational education began in 1950 with a record enrollment of 415,388 and dropped to 259,726 by 1952. "The anxleties emanating from the Cold War, the problems of a turbulent economy, and the growing restlessness of a troubled society combined to stop innovative strategies throughout public education, including vocational education" (Smith, 1979, p. 44). Sputnik I raised questions as to the effectiveness of the public schnols. Lannie (1971) explained that vocational education fluctuated with the increasing criticism of public education. Critics charged the schools with being "Intel lectually mediocre" and courses in vocational education did not appear to prepare a sufficient number of adequately training young people (Lannie, 1971, p. 16). Vocational education initiated a self-examination with year-long analyzes of programs and curricula. Programs stood at a stand-still, while assessments and evaluations flocked the educational scene. The information received 
provoked alternative directions and generated new commi tments (Smith, 1979).

The 1960-1970 Decade

The 1960 's were considered the most eventful years in the history of vocational education (Smith, 1979). Enrollments more than doubled in Callfornia with school district expenditures increasing from $\$ 18$ million in 1960 to more than $\$ 50$ million in 1970 . Three immensely significant acts were implemented during these years:

1. the Manpower Development and Training Act (MDTA) initiated to combat the problems of unemployment;

2. the Vocational Education Act of 1963 designed to remove the constraints contained in the Smith-Hughes Act of 1917

3. the Vocational Education Act of 1968 which evaluated the impact of the VEA upon vocational education within four years.

The MDTA was responsible for the establishment of hundreds of training centers across. the country designed to fit the needs of the unemployed. These MDTA programs were administered by the State Employment Agency and the State Vocational Education Services. Funding was completely federal with trainees receiving stipends during the training period (Roberts, 1971; Smith, 1979).

The Civil Rights Movement of the $1960^{\prime}$ s influenced the course of vocational education and, due to the efforts of 
President Kennedy, the Smith-Hughes Act was evaluated and reviewed. President Kennedy delegated a panel of consultants on vocational education whose responsibility was to review and recommend additions and changes to each provision (Barlow, 1967; Evans, Mangum \& Pragan, 1969; Lannie, 1971; Roberts, 1971). A concern for accessibility of all persons in vocational education clearly paralleied the nation's efforts to provide for all its citizens. "The intent of the new law was obvious. Vocational education opportunities should become universal-in all locations, for all persons, and for almost all occupations" (Smith, 1979, p. 49). The panel found two principal failures of vocational education: ( 1 ) the lack of sensitivity to the labor market and (2) the lack of sensitivity to the needs of certain populations in society (Walters, 1986). The panel recommended allocations of funds based upon six new categories:

1. vocational education for persons attending high school;

2. vocational education for persons who had completed or left high school:

3. vocational education for persons who were in the labor market and needed training or retraining;

4. Yocational education for persons who had academic, socioeconomic, or other handicaps that prevented them from succeeding in regular vocational education programs; 
5. construction of vocational education school facllities; and

6. ancillary services, such as evaluation, teacher training, and research (Walters, 1986).

The Vocational Education Act of 1968 was the outcome of an evaluation made on the impact of the VEA of 1963. "The new law retained all uses permitted under the 1963 Act but made significant changes" (Wall, 1976, p.30). Some of the changes occurred as follows: (1) funds were earmarked not only for those with social, academic and economic handicaps, but also for physically and mentally handicapped workers; (2) vocational guidance and counseling recelved support; (3) private vocational training institutions were instituted; (4) cooperative education was given its own budget; (5) post secondary vocational education received specialized monies; and (6) the definition of vocational education was broadenea to include prevocational orientation, employability skills and job placement (Roberts, 1971; Walters, 1986). The 1968 amendments provided a substantial increase in federal funding, totaling $\$ 27.6 \mathrm{mill}$ ion for the state of California (Fowler, 1976).

The 1970-1980 Decade

Responding to a long-time need for systematic research in vocational education, Congress provided for extensive use of federal funds for this task through both the 1963 and 1968 amendments. This feature resulted in study efforts at 
the state and local levels, pilot demonstration programs and innovative projects during the forthcoming years. The 1970 's began with evaluations of these studies and projects ascertaining the importance and value of vocational education in the public school system. New amendments were added to the VEA of 1968 to increase federal funding in 1976. Added features of the 1976 Educational Amendments included grants to overcome sex bias, funds to assist in state planning, renovation of facilities, and additional funds for preservice and inservice training for teachers (Smith, 1979).

Walters (1986) explained the allocations of funds. A portion of the basic state grant funded by the Educational Amendments of 1976 were set aside for the following: (a) handicapped at 10 percent; (b) disadvantaged at 20 percent; (c) programs for $1 \mathrm{imited}$ Engl ish language up to 5 percent; and (d) programs of national significance at 5 percent. The VEA of 1976 coincided with other major pieces of legislation designated to meet the needs of persons with handicaps, which included Section 504 of the Rehabilitation Act of 1973, the Educational for All Handicapped Children Act of 1975 and the 1976 Lanterman Act. Cross (1980) remarked that the 1970's marked a new era for the education of persons with handlcaps which included the right to an education and accessibility to vocational education programs. Phelps (1982) reported that the implications of these pieces of 
legislation were the inclusion of persons with disabilities into all programs at all levels.

\section{The 1980's}

Meers ( 1980 ) referred to the $1980^{\prime} \mathrm{s}$ as the age of implementation. He suggested that since leglslation passed that enabled all sectors of the public to participate in school, work, and community activities, the challenge of the $1980^{\prime} s$ would be the implementation of these activities. Persons labelled "handicapped" were provided prevocational programs, exemplary vocational programs, and mainstreamed vocational classes in secondary and postsecondary schools. The Carl D. Perkins Vocational Education Act of 1984 reemphasized and strengthened the commitment to offer equal educational opportunities to students in special group categories (Markowicz, 1985).

There were two major purposes of the Perkins Act: (a) to provide vocational education services specificaliy for persons with special needs, and (b) to enhance the innovation and improvement of programs. Part $A$ of Title II set aside 57 percent of the funding for six target populations, and Part B authorized 43 percent of the funds for program improvement, innovation, and expansion (Brustein, 1987). The six targeted populations defined in the law and the set-aside funds were:

1. handicapped individuals ( $10 \%)$;

2. disadvantaged individuals ( $22 \%)$; 
3. adults who are in need of training and retraining $(12 \%) ;$

4. individuals who are single parents or homemakers $(8.5 \%) ;$

5. individuals who participate in programs designed to eliminate six bias and stereotyping in vocational education $(3.5 \%)$;

6. criminal offenders who are serving in correctional institutions $(1 \%)$, (Wisconsin State Department of Publ $1 \mathrm{c}$ Instruction, 1985).

The portion of funding allocated for persons who were considered handicapped was 1 imited to "supplemental or additional staff, equipment, materials and services not provided to other individuals in vocational education that are essential for handicapped individuals to participate in vocational education" (Carl D. Perkins Vocational Education Act, 1984). If separate programs were deemed necessary for persons with disabilities, the law stated that "each state may use such funds for the Federal share of the costs of the services and activities in separate vocational education programs for handicapped individuals which exceed the average per-pupil expenditures for regular services and activities of the eligible recipient" (Carl D. Perkins Vocational Education Act, 1984). In summary, federal funds allocated for persons with disabilities maintained an excess cost requirement. 
Sathre (1987) explained that the Perkins VEA is presently responsible for only ten percent of all vocational funds in the nation. Bottoms and Copa (1983) found that it is these funds that have served to support the expansion of vocational education programs in areas that lack sufficient resources of their own to meet these needs. There has existed a controversy in Congress as to the importance of federal funding since these funds only represent a small portion of aid to vocational education today (Shoemaker, 1987). Vocational educators expressed a concern over the 1989 expiration of the Perkins Act. Hollenbeck and Stevens (1987) proposed that while these funds are I imited, they continue to serve two essential purposes: (a) "Federal funds leverage local, state, and private-sector investments, which would not be forthcoming otherwise;" and (b) "federal funds offer opportunities to those who would otherwise not be attractive candidates for employment" (p. 17).

Purpose 1: Federal funding strengthens state and local suppert. Vocational educators advocated that federal funds set the pace for the development and advancement of programs in vocational education (Bottoms \& Copa, 1983; Sathre, 1987; Shoemaker, 1987). Shoemaker (1987) found that federal funds have been the key factor in the increased allocations of state and local monies. Roberts (1971) stated that federal aid enabled the states to maintain certain standards. He felt that if only state and local monies were available, 
these standards would not continue in vocational education. Historically federal funds have proven to serve as a "catalyst for innovation and change" "Bottoms \& Copa, 1983, p. 351). It is believed by vocational educators that without federal investment the system of vocational education would be seriously curtailed (Shoemaker, 1987). Purpose 2: Federal legislation mandates services for persons with special needs. The VEA of 1963 and 1968 emphasized the importance of vocational education for groups with special needs. Roberts (1971) advocated the Importance of these funds since states were not able to finance the cost of vocational education for these groups without assistance from the federal government. Conaway (1987) explained that these funds are still as critical today. The Perkins VEA mandated the delivery of assessment, support services, counseling, and transitional services for students with disabilities (Rusch \& Phelps, 1987). Conaway (1987) stated that the most essential components of vocational education for students with disabilities are the supplemental services needed to meet their special needs. The excess cost requirement of the Perkins VEA provided federal support for these services.

Davis (1987) listed the supplemental services that may be provided by VEA funds. They were, as follows: 
1. modifications and adaptations of curriculum materials, such as specially designed textbooks, large print materials, and written instruction in braille;

2. equipment modification in the vocational environment, such as sensory devices, teletypewriters, and special work tables for wheelchairs;

3. specialized equipment required for participation in vocational education programs;

4. outreach activities, such as recrultment of potential employers, flyers, and speaking engagements $w / t h$ community groups;

5. additional assessment services to assess the interests, abilities, and special needs of the students;

6. specialized guidance, counseling, and career development activities, including recruitment, referral, and follow-up;

7. additional job placement services;

8. remedial services, such as additlonal technlcal skills remediation;

9. separate vocational programs for students with disabilities who cannot succeed in regular vocational classes;

10. additional staff required to implement the above services; and 
11. staff development needed to certify vocational education personnel to work with students who are alsiled (pp. $10-14)$.

The California State Department of Education produced a documentation guide for Perkins VEA programs ana services. The guide reported that all personnel must meet certain criterla and individuals who provide supportive services to students who are disabled must have the background and credentials to qualify them to provide those services. Inservice was an area addressed by Conaway (1987) as an essential component to ensure quality programs for persons with disabilities.

Shill (1976) explained that while programs expandea for persons in special groups, sufficient numbers of tralnea personnel were not available to meet the demana. Criticai shortages of trained personnel became obvious auring the late $1970^{\prime} \mathrm{s}$. Sh1ll related this shortage to the many conflicting theories proposed by psychologısts and a lack of information on disabilities, particularly regarding specific learning disabilities. Miller, Sabatino and Larsen (1980) found that the majority of classroom teachers, vocational teachers, and special education teachers knew littie about the needs of students with disabilities. Federal funding became critical to ensure that the quantity of inservice and preservice programs increased in the 1980's (Batsche, 1980). 


\section{Summary}

Little research has been found to address what services and activities are actually being provided to students with disabilities in the $1980^{\prime}$ 's through VEA funding. Congress will pass a new law by the end of 1988. Buzzell (1987), the executive director of the American Vocational Assocation, urges vocational educators to advocate for programs and services designed for persons with special needs through VEA funds. He states:

Where we have been successful, we must do everything in our power to acquaint our congressional leaders, state legislative leaders, and local school boards and policymakers with those successes. It is incumbent upon us. No story is too small. No success is insignificant. I urge each of you to tell your story to the people who are going to be making the decisions about the investment of taxpayers' dollars.. The window (of opportunity) is open now, but it will not be for long (p. 8).

The year 1988 begins a period of analysis in Congress on the effect and need for federal funds in vocational education. Special interest groups are seeking information on key issues and positions regarding services provided by the Perkins Act. There exists a critical need for services to be identified and documented for legislative review. 


\section{Vocational Education in California Community Colleges}

Vocational education took its place within the community college system with the establishment of the American Association of Junior Colleges in 1920. While the original function of the community colleges was to provide a two-year baccalaureate program, strides were taken in the early years to establish a strong vocational education curricula (Smith, 1979). Community colleges are defined as: "A two-year, postsecondary, degree-granting institution (that may also award certificates and 1 icenses), which offers a comprehensive instructional program in both generai and vocational and technical education and a transfer program to institutions of higher education" (Bottoms \& Copa, 1983, p. 350). Any high school graduate or person over 18 years is eligible for admission. The Development of the Community College

Thornton (1972) proposed that the present day community college has evolved through four major stages which are: (a) the evolution of the junior college, 1850-1920; (b) the expansion of occupational programs, 1920-1945; (c) the community college concept, 1945-1965; and (d) the period of consolidation, 1965. The junior college slowly evolved into

a separate institution during the 1850-1920 period (Thornton, 1972). The first terminal vocational courses were provided by Chaffey Junior College in 1916. Courses 
provided at Chaffey included home economics, commerce, library training, general agriculture, and farm mechanics. "Passage of federal vocational education bills during Worla War I had attracted attention of public junior colleges desirous of sharing in the grants provided" (Thornton, 1972, p. 53). Community colleges could receive financial support for the institution of vocational classes through federal funds allocated by the Smith-Hughes VEA.

Smith (1979) reported that during 1920-1930, 22 new colleges joined the 11 already created during the 1910-1920 period. Enroliment of students increased from 1,096 in 1920 to 10,000 students in 1930. Expansion of occupational programs marked the years 1920-1945 (Thornton, 1972). Following the first world war most practioners of vocational education concentrated on unemployment (Smith, 1979, p. 20). The junior college established itself as a valuable segment of public education, and a commitment to vocational training of the nation's youth and adults was well established (Field, 1962). Enrollment in California junior colleges continued to increase, growing to 60,000 students by 1940 . Forty-six percent of these students enrolled for employment purposes (Smith, 1979).

The recognition of the success junior colleges had on producing war production workers during the war years and their ability to retrain veterans following the war led to the transference of the concept of the junior college to a 
concept of the community college. Since the junior college had proven valuable to the needs of the nation, the concept of the community college achieved full acceptance. Byron Holl insheed explalned this concept:

That the junior college should be a community college, meeting community needs; that it should serve to promote a greater social and civic intelligence in the community; that it should provide opportunities for increased adult education; that it should provide education, recreational and vocational opportunities for its young people; that the cultural facilities of the institution should be placed at the disposal of the community; and that the work of the community college should be closely integrated with the work of the high school and the work of other community institutions (Thornton, 1972, p. 55).

Thornton (1972) explained that the concept of the community college had been fully developed by 1965 . The tasks of the community college had been widely accepted as they developed over the years, but in the late $1960^{\prime}$ 's there had been a continuous reallzation that these tasks were only partially fulfilled. The open-door concept that emerged from the mission of the community college appeared only in theory. Important societal changes țook place during the $1960^{\prime} \mathrm{s}$. McCabe (1981) explained that "the nation struggled to overcome the impact of a history of racial 
discrimination, and to provide equality and protect the civil rights of all Americans. In response, the community colleges opened their doors to all who wished to enter" (p.7). The period of consolidation was a time when the community colleges questloned and critically examined their obligations. Thls resulted in a full scale evaluation with the following developments: (a) occupational education and transfer education were reexamined and "modernized", (b) the recruitment of minority students was undertaken, (c) college programs were situated on off-campus sites to provide accessibility for persons in the community, and (d) a higher emphasis was placed upon guidance and counseling (Thornton, 1972).

\section{Community Colleges Today}

The Carnegie Foundation (1977) suggested that community colleges today are the most diverse colleges in our country. It stated that "not only are they distinctive as compared to one another, but they also pride themselves in encouraging diversity of programs within each college" (p. 128). Diversity served to meet the needs of all types of students to provide increased opportunities for intellectual, social and personal growth. The literature reported five philosophical bases from which the community college attempted to assure accessibility and opportunity. These are considered the bases of the characteristics of community colleges today and are: 
1. the community college is democratic, implemented by its low cost and open accessibility;

2. the community college is comprehensive, offering a multiplicity of services and programs;

3. the community col lege is community-centered, controlled and supported by the community;

4. the community college is dedicated to i ifelong learning, providing services to the needs of adults both young and old through adult education and continuing education; and

5. the community college is adaptable, offering transfer, occupational, remedial, community service and continuing education programs that respond to the changing needs of society (Cohen \& Brawer, 1972; Deegan \& Tillery, 1987; Fields, 1962, Thornton, 1972).

McCabe ( 1981 ) posited that during the past three decades, American community colleges have met the challenge of expanding access to postsecondary education. New opportunities were developed for persons who were previously excluded to receive training and education necessary to fully participate in society. Part-time students outnumbered full-time students by more than 10 percent (Cohen \& Brawer, 1977). Community colleges became known for providing services to a new kind of student:

Community colleges are in the forefront in servicing the needs of the nontraditional student and in 
providing equal access to educational opportunity. Women, minority group members, returning older students, and bilingual or foreign students have all been given opportunities to pursue academic and vocational goals. In recent years, severely handicapped people have joined these other groups in seeking higher education (Terzlan \& Thompson, 1986, p. 39).

McKay (1982) stated that as compared to the traditional four-year college, the community college requires faculty to innovate and adapt learning experiences to provide access to these nontraditional students. It was found in a comparison study of faculty from two-year colleges and universities that instructors in the community colleges were more interested in their teaching. Cohen \& Brawer (1977) observed that "community college faculty are usually characterized as being more willing to work on their teaching, changing courses in accord with varying student abilities and individualizing instruction where possible" (p. 39). The community college provided a unique opportunity and challenge for instructors to meet the needs of students with varying backgrounds and different learning styles.

\section{Students with Disabilities in the Community colleges}

Phillips (1986) identlfied the community college as the "greatest single provider of postsecondary education to students with handicaps" (p.24). Bell (1981) noted that the 
subject of accessibility for students with disabilities into community colleges has generated much interest. Accessibility refers to the inclusion of students with disabilities into regular education programs.

Phillips (1986) advocated that in order to have programs readlly accessible, architectural barriers must be removed. Phillips reported that many colleges constructed after 1975 were totally barrier-free. Other colleges constructed in the $1960^{\prime} \mathrm{s}$ underwent renovation to accommodate for students with disabilities on their campuses. Johns (1982) explained that accessibility also includes program accessibility. Programs and activities were made accessible through modifications in practices and policies, such as testing accommodations at colleges to the simple use of tape recorders in classes.

The Chancellor's offlce reported that there were 39,376 students with disabilities in Cal ifornia community colleges during the 1979-1980 school year (Report to the Legislature, 1981). Successful placement of students with disabilities within community colleges has been revealed in the literature (Bell, 1981; Phillips, 1986; Terzian \& Thompson, 1982). Students received instructional services in regular and special college classes, sheltered workshops. and in state hospitals. The largest group of students served had mobility problems and the second largest group had learning disabilities (Expanding Educational 
Opportunities, 1986). Other disabilities served included students with developmental disabilities, acquired brain injuries, health impairments, speech and hearing deficits, and vision impairments.

\section{Vocational Training of Students with Disabilities}

Lou Harris and Associates (1987) conducted a nationwide survey of 1,000 Americans with disabilities. The results found that Americans who were disabled had far less education than non-disabled Americans and the majority of persons with disabilities were unemployed. Sixty-six percent of persons with disabilities were reported outside the labor force. The cost of unemployment for persons with disabilities was considerably high (Feller, 1986; Will, 1984). Many people received significant amounts of government support or assistance from programs funded under special education, vocational education and vocational rehabilitation. One of these agencies, vocational rehabilitation, spent $\$ 1$ billion 251 million in 1980 to train individuals with disabilities in occupations sulted to their abilities (Bureau of Census, 1984; Combs \& Omvig, 1986). Such large expenditures of funds coupled with the low employment rate led researchers to question a number of issues: (a) are certain disabilities more acceptable in employment than others? and (b) what types of training 
programs are more successful in the placement, training and retention of persons with disabilities in the work force? Barriers to Employment

Lebed (1985) suggested that the greatest barrier to the. employment of persons with disabilities was not their handicaps but rather resulted from employer prejudices. Howard and Johns ( 1986 ) observed that "undereducation and lack of marketable skllls is listed as the second most significant reason disabled respondents are not working, second only to the fact that employers won't recognize that they are capable of doing a job because of their disability" (p. 14). Several researchers have explored this obstacle. Mithaug (1979) found that certain disabilities were more acceptable than others. Persons with physical handicaps were more acceptable for employment, while persons with severe retardation were found to be less acceptable. Combs and Omvig (1986) examined att Itudes toward sixteen disabilities in 75 companies. They found that employers felt they could more easily accommodate some disabilities than others. Impaired speech seemed to be the most easily accommodated, whlle persons with severe retardation were considered to be the most difficult.

Some of the most important factors that affected an employer's decisions for hiring persons with disabilities were identified in Mithaug's survey of 43 companies in 1979. The employers revealed that the most important concerns were 
over the ability to perform the job, productivity. compliance with affirmative action, and absenteeism. Burton, Chavez and Kokaska (1987) conducted a survey whlch revealed that the majority of employers were more concerned with social-personal job skills, such as dependablitity. pride in work, respect for authority, and the ability to get along with others. Patterson and Witten (1987) found that many employers have developed a variety of misconceptions regarding the hiring of persons with disabilities. Lester and Caudill (1987) believed that these misconceptions have developed into myths. The most commons myths regarding hiring the person with a disability were identified as:

1. They have a higher turnover.

2. They are less productive.

3. They are a greater safety risk.

4. They are too costly.

5. They are too demanding.

6. They would be an embarrassment to the organization.

7. They won't fit in the organization's work groups. (Lester \& Caudi11, 1987).

All of these myths have been refuted in the literature. Literature in the field of special education and rehabilitation clearly demonstrated that individuals with disabilities can successfully work. Bellamy, Bertrand and Horner (1979) reported that persons with disabilities performed as well or better on a wide range of jobs. 
Greenwood and Johnson (1985) reviewed 90 surveys conducted during the last 40 years on employers concerns regarding the employment of workers with disabilities. They found that increased motivation evidenced by employees with disabilities counterbalanced any other factors that effected productivity, such as educational status. The Governor's Committee for Employment of the Handicapped reported that while employers felt that workers with disabilities were likely to have accidents, research showed that $98 \%$ of employees who are disabled had better to similar accident records (Employing Workers, 1981). Rochl in (1987) responded to the belief that workers with disabilities were too demanding and stated that when supervisors were provided with proper information on how to instruct persons with disabilities, training was not a difficult task.

A review of literature in the field of business also suggested that persons with disabilities produced as well as, and in some cases, better than their co-workers cParent \& Everson, 1986). The employment of persons with disabilities became a topic of interest in business journals. Persons who are mentally retarded, physically handicapped, hearing impaired, and learning disabled have beẹn reported working in insurance companies (Lyons, 1982), Xerox and Sears, Roebuck and Company (Pati \& Morrison, 1982) and Fortune 500 companies (Mithaug, 1979), among others. Researchers have cited concerns over negative attitudes of 
employers toward hiring (Jamero,1979; Lester \& Caudill, 1987). Other studies showed the fallacies of the misconceptions and myths. Ashcraft (1979) found that hiring persons with disablitities did not increase costs, and reported that insurance costs remained the same and accommodations on the job were minimal. Lasden (1982) and Wysocki and Wysocki (1979) discussed the DuPont study which studied over 1,000 workers with disabilities. The results of this study indicated that: (a) $96 \%$ of the workers rated better to average on safety factors; (b) $93 \%$ rated average or better on job stability; (c) $91 \%$ rated average or better on job performance; and (d) $71 \%$ rated average or better on their attendance records.

The evidence has demonstrated that persons with disabilities can work well in business and industry. The negative attitudes and misconceptions employers had for persons with disabilities in employment remained difficult to overcome. Shworles and Wang (1983) suggested that persons with disabilities would have to overcome stereotypes by proving themselves to be more competent and committed than most other job seeking individuals. Weiker (1987) stated that the reasons for high unemployment among persons with disabilities not only result from societal attitudes, but also from the lack of an effective transition process from school to work, physical and communication barriers in buildings, transportation and work sites and a lack of 
training opportunities for persons with disabilities. Celis (1987) concurred that most adults cannot $f$ ind ongoing support and training following their high school years. Education and training for work in the community has become critical for the person with a disability entering a job and for the individual who has broken the barrier and strives to maintain hls/her employment.

\section{Models of Employment Training}

Wehman, Hill, Goodall, Cleveland, Brooke \& Pentecost (1982) explained that the job placement and training of persons with moderate and severe disabilities has received serlous attention within the past ten years. Early emphasis was placed on the training of persons with severe handicaps in sheltered workshops or adult day programs. Studies reported that adults with severe disabilities adequately performed work tasks in sheltered workshops throughout the country during the 1970's (Bellamy, Inman \& Yeates, 1979; Gold, 1972, 1974, O'Neill \& Bellamly, 1978). These studies revealed that while some individuals worked at a slower pace, many of them proved to be reliable employees. It was assumed that competitive employment was impossible for persons with severe retardation, but the work demonstrated that employment was problably much more likely than thought. previously.

Wehman, Hill \& Koehler (1979) suggested that there are many disadvantages to preparing individuals with retardation 
to work in sheltered workshops. The findings reported that: (a) sheltered workshops rarely paid workers minimum wage;

(b) sheltered workshops were restrictive in that only workers with handicaps were included; (c) fringe benefits were rarely provided; and (d) sheltered workshops were terminal placements for workers with severe handicaps providing little chance for advancement or opportunity.

The realization that sheltered workshops were restrictive work environments and not necessarily positive settings for persons with disabilities brought forth new hopes and promises for persons with disabilities. New models for employment were needed to prepare a new generation of youth and adults to lead integrated productive lives. Three alternative models of employment training developed and included: (a) the enclave model (Mank, Rhodes \& Bellamy, 1986), (b) the mobil work crew model (Borbeau, 1985), and (C) the supported employment model (Wehman, 1986; Wehman \& Hill, 1985; Wehman, Hill, Hill, Brooke, Pendleton \& Britt, 1985). Efforts toward employment directed away from sheltered environments into less restrictive or nonsheltered work settings which focused on competitive positions (Wehman \& Kregel, 1983).

The enclave medel. The enclave was designed for persons who needed continued daily support (Hill, Hill. Wehman, Revell, Dickerson \& Noble, 1987). The enclave was defined as a group of individuals with disabilities who 
worked with special training within a business (Thodes \& Valenta, 1985; Wehman, Kregel \& Barcus, 1985). Payment for work was commensurate with pay to others within the company doing the same type of work and amount of work (Mank, Rhodes \& Bellamy, 1985). Persons with disabilities worked along side their nonhandicapped co-workers. They received the same benefits as other workers in the company, such as working hours, break times and performance evaluations.

The mobil work crew model. The mobil work crew model was set up as a small business with a crew of approximately five individuals with disabilities performing service jobs (Mank et. al, 1986). Payment was made to a non-profit agency. Groundskeeping and janitorial work were the most common contracted jobs. A crew typically worked out of a van, traveling to the work site. The benefits of this model were wages paid to the worker and communsty integration involved while at work.

The supported employment model. The supported employment model received the most attention since it was based upon the philosophy that persons with disabilities when provided with ongoing support would achieve higher goals and meet higher work expectations (Wehman \& Kregel, 1985). The model advocated integration of persons with disabilities into paid competitive jobs. The employer pald the worker at or above the federal minimum (Hill, et. al, 1987). Ongoing job coaching and advocacy was provided by 
service agencies (Hill, et. al, 1987) and new types of staff were developed such as job coaches and job placement specialists (Wehman \& Mella, 1985). "A trained job coach develops the job in the industry, matches an individual to the job, trains the individual on the job until performance criteria are met and provides on-going follow-up support as long as necessary" (Program for the Handicapped, 1984, p.29). Wehman and Kregel (1983) suggested that the ultimate goal of the supportive work model of employment was to "enable each individual to acquire and retain a satisfying job in a competitive setting" (p. 3). Three criteria which met the qualifications for a program to be considered "supported employment" are:

1. The Individual should be involved in employment where the employer paid wages.

2. The individual required ongoing support.

3. The individual must have demonstrated opportunities to integrate with persons on the job who are nondisabled. (Program for the Handicapped, 1984).

Revel1, Wehman \& Arnold (1984) stated that in the supported employment model students not only gained employment but also developed skills at the job, adjusted to the work environment, and ultimately retained the job. This was accomplished through the following four components of the model: job placement, job-site training, on-going assessment, and job retention. Wehman \& Kregel (1985) 
explained that social skill and behavioral skill training procedures were incorporated into this program.

The number of programs utilizing the supported work model increased during the $1980^{\prime}$ 's (Revell, et. al, 1984). Many follow-up studies have been conducted throughout the country to evaluate the outcomes of job placement through supported employment programs. Vogelsberg (1986) reported that 73 workers labelled mentally retarded or severely disabled were successfully placed in Vermont. Wehman (1986) noted that 145 persons with mental retardation were successfully placed in Virginia with job retention estimated at 15.5 months. Moss, Dineen \& Ford (1986) found that of 70 persons with severe mental retardation in Washington 66 percent were successfully employed in jobs after six months. These findings reported positive outcomes for persons with disabilities participating in this model. Current research has indicated that many more follow-up studies were now being conducted to determine the effectiveness of this approach (Brown, Rogan, Shiraga, Albright, Kessler, Bryson, Van Deventer \& Loomis, in press).

Cost analysis studles were another attempt at determining the outcome of the supported competitive employment model. Noble and Conley (1987) reported that sufficient information existed to argue that all forms of employment were more productive in terms of earnings and savings as compared to adult day care. Wehman \& Hill (1983) 
conducted a 4-year cost analysis of students placed through the supported employment model. This study was extended an additional four years and reported in 1987 by Hill. Wehman, Banks \& Metzler (in press). Factors examined in the cost analysis included the number of months worked by the individual, the amount of staft hours expended at the work site, the amount of funds expended proportionately on each person, the Supplemental Social Security Income saved, estimated cost of day programming if no job placement was made, Targeted Job Tax Credit Program costs, and the amount of state and federal taxes withheld. The public's cumulative savings after eight years totaled $\$ 1,057,000$, of which $\$ 525,000$ was a direct benefit placing consumers with persons with moderate to severe disabilities in supported competitive employment, as opposed to alternative programs (Hill, et al, in press). This data showed a substantial savings to society. The results indicated significant financial benefits, as well as the expansion of opportunities for persons with moderate and severe disabilities.

Reqular mainstreamed programs. The enclave model, mobil crew model, and the supported employment model referred to programs specially designed for persons with disabilities. Whlle many students participated in these programs, many more students with disabilities attended mainstreamed regular vocational education classes for 
training. Bottoms \& Copa (1983) estimated that 400,000 vocational education students have disabilities. Most of these students were mainstreamed into regular programs.

The nature of vocational education classes in regular programs were classified into two categories: general and occupationally specific. General vocational education programs were designed to provide "a foundation for career decisions, to develop the prerequisite skills to master an occupational area, and to develop the gener lc skills useful both in work and in everyday life" (Bottoms \& Copa, 1983, p.349). There were five kinds of general vocational education programs: consumer/homemaking programs, pre-vocational programs, pre-vocational basic skills programs, related instruction, and employability skills programs. The occupationally specific vocational programs had as their primary focus "instruction in content and skills that are necessary for employment in a specific job or occupational area" (Bottoms \& Copa, 1983, p. 349). These programs were grouped into four types: occupational-cluster programs, occupationally specific programs, job-specific programs, and employer-specific programs. 


\section{Vocational Trainlna for Students with Disabilities \\ in the Community Colleges}

Students with disabilities attending community colleges received instruction in on-campus regular and special classes, off-campus sheltered workshops and state hospitals. Special vocational placement and training programs as well as mainstreamed regular vocational education classes were available to students with physical disabilities, developmental disabilities, communicative disorders, ana learning disabilities (Report to the Legislature, 1981). Community colleges across the nation became "an essential ally in the vocational education and vocational rehabilitation process of handicapped persons" (Wall, 1976. p. 143).

Hartman (1981) observed that the majority of students with disabilities entered California community colleges to receive vocational preparation and to reach their career goals. Howard and Johns (1986) explained that the Cal ifornia Community Colleges have established the Disabled Student Programs and Services (DSP\&S) to help students with disabilities attending community colleges acquire the marketable skills needed to compete and advance in the job market. Over 50,000 students per year have been served by DSP\&S (Howard \& Johns, 1986). 
The Chancellor's Office of the California Community Colleges funded several projects to identify vocational services provided to students with disabilities since 1985. One such project reported on the Employer-Based Training Program (1986) conducted through community colleges which trained unemployed and displaced workers for jobs in industry. The report described thirty projects throughout California, such as Micro-Computer Repair at Merritt College, Small Business Training at Cabrillo College and the Industrial/Milltary Electrical Technician Program at Oxnara College. These programs were funded at the state levei from provisions of average daily attendance, with some institutions using matching VEA funds (Chancellor's Ofíce, 1986). A second report resulted in a directory on California community colleges exemplary programs and materials for students with disabilities (Wright, Kim \& Wing, 1985). Programs listed were funded with DSP\&S funds. While some data gathering and research has been reported, still limited information exists on vocational services available through the community colleges.

A revlew of literature indlcated a serious shortage of research on vocational services and training for students with disabilities at the postsecondary level. Wall stated in 1976 that of "700 or more literature abstracts, only a handful reflect vocational education programs for the handicapped at the postsecondary level" (p. 146). An ERIC 
computer search with descriptors provided by the National Center on Research in Vocational Education yielded similar results in the 1980s. The "Vocational Education Act" coupled with "disabilities" and "postsecondary education" cited only 11 articles.

Community colleges have met the growing demands of students from unique and different populations by developing new programs, modifying curricula, and adapting to the diversity of students' learning styles. Current research is needed to examine what services and programs are being provided and to what extent these activities are reaching the population of students with disabilities.

\section{Summary}

The literature revealed a historic role of federal funds in the development of vocational education. Federal legislation has influenced the direction of vocational education since the early 1900's. Students with disabilities gained access to vocational services with the passage of the VEA of 1963. Subsequental amencments to this Act, earmarked funds specifically for special needs populations. Programs and services developed across the country; community colleges were one of the first institutions to open their doors. Students with disabilities entered community colleges seeking instruction which would assist and support them in gaining employment. 
One of the original functions of the community colleges was the occupational preparation and vocational training of adults. The concept of the junior college transformed into the community college with an open door policy encouraging accessibility and educational opportunities for all people. New types of students enrolled including women, part-time students, minority students, foreign students, older students and students with disabilities. Over 50,000 students with disabilities were being served in California community colleges. A majority of these students enrolled in vocational classes and received specialized vocational services. Community colleges provided special accommodations for students with disabilities to enter classes, including testing accommodations for enrollment. Complying with the 1973 Rehabilitation Act, community colleges addressed both physical and program accessibility issues. Students with disabilities were encouraged to participate in mainstreamed classes and the community colleges were soon found to serve the greatest number of students with disabilities as compared to other postsecondary institutions.

Vocational training for persons with disabilities began in sheltered workshops. Research findings reported many disadvantages to working in a sheltered environment, and new models of employment training were developed. The enclave model, mobil crew model, and supported employment model were 
the most common models $1 \mathrm{mplemented.} \mathrm{These} \mathrm{models} \mathrm{were}$ designed specifically for persons with disabilities to provide on-going job support. Many students benefited from these programs but not all persons with disabilities needed these approaches. Other students proflted from integration into regular mainstreamed classes. The community colleges provided instruction in both regular and special vocational programs. Students with disabilities benefited from these programs as they enter the world of work; breaking down barriers of negative attitudes, myths, and misconceptions about them and their potential for job performance.

Services provided by VEA funds for the education of students with disabilities enhanced student participation in vocational programs with career planning, assessment and counseling support. Additional services were arranged for personnel training, curriculum development, and program modifications. The controversy over the importance of federal funding in providing vocational education services threatened the future for persons with disabilities. While the funding was I imited, it provided financing for such essential services. 
CHAPTER THREE

Methodol ogy

Thls study examined the use of Vocational Education Act (VEA) funds in the Disabled Student Programs and Services of Cal ifornia community colleges during 1987-88. The purposes of the study were: (a) to examine the distribution patterns of VEA funds within community college districts, (b) to identify services for students with disabilities funded by the VEA in each college, and (c) to ldentify the disability groups who received these gervices. Survey research was the methodology that formed the basis of this study. Two technlques were utilized for collecting survey information that responded to the research questions. These techniques included: ( $a$ ) the examination of records and (b) a questionnaire. The following research quest ions were addressed.

Research Questlon Number 1. How were the VEA funds allocated wlthin the Disabled Student Programs \& Services (DSP8S) during 1987-1988?

The following three subsets responded to this question.

1. What percentage of the total VEA Title II-Part $A$, Basic Grants was allocated in each district to students with disabilities? 
2. What was the comparison of VEA funding for students with disabilities compared to funding allocated to each college for DSP\&S?

3. What was the distribution of VEA expenditures during 1987-88 for students with disabilities?

Research Question Number 2. What programs and services provided for students with disabilities in California community colleges were funded by the Perkins VEA?

The following five subsets responded to the second research question.

1. What activities and services that meet the requirements of VEA funding were provided to students with disabilities?

2. What categorles of disabilities recelved services through VEA funding?

3. What percentage of colleges received funding under VEA Special Projects for exemplary programs and special projects?

4. What models of employment were utllized in colleges that provided special vocational programs? 
5. What was the composite of special vocational programs in colleges that identified model or exemplary progr ams?

Reseacch Questlon Number 3 . What areas of training did participants receive regarding VEA funding and what areas of training dld they identify as current needs?

Four subsets responded to this research question.

1. In what areas have DSP\&S staff received the most training?

2. How did the participants perceive the usefulness of thelr training?

3. What areas of needs were identifled by the participants for training?

4. What delivery methods were identified as the means for potential training?

\section{Reseacch Desian}

Procedures for gathering the data for thls study included the following:

1. Examination of the 1987-88 VEA budgets from all districts.

2. Examination of the DSP\&S 1987-88 allocation report. 
3. The development of a questionnalre.

\section{VEA Budget Reports.}

Fifty-seven of 70 VEA appllcations and budgets for 1987-88 were obtained from the Office of Vocational Education of the Callfornia Community Colleges. These copies were sent to the researcher and utilized to examine the distribution of funds throughout California community college districts. Each report included the overall VEA budget and all categorical funds allocated to each district. DSP8S 1987-88 Allocation Report.

The researcher obtained a copy of the 1987-88 DSP\&S Allocation report. This report provided information on the amount of DSP\&S funding received during 1987-88 for each district.

The Questionnaire.

The procedures followed in the development and use of a questionnaire included: (a) construction of the questionnaire questions, (b) the pilot test, (c) the cover letter, (d) mailing and follow-up.

Questionnalre construction. The construction of the questionnaire was based upon Covert's Guidelines \& Criteria for Constructing a Questionnaire (1977). The researcher followed each step delineated by Covert. These addressed the following six categories: the title, introductory statement, directions, demographlc section, structure and format, and writing items. With the assistance of 
individuals who participated in the pilot study, the questionnaire was redesigned to best meet the criteria.

Pilat Tegt. A pilot test to evaluate the questionnaire was conducted in the San Diego Community College District and presented to: (a) a coordinator of special programs who is directly in charge of VEA funding within this district and (b) a college speclalist who has responsibllity for overseeing the vocational services provided to students with disabilities within the northern region of the San Diego area. Both of these individuals had the knowledge and expertise to provide the information requested by the questlonnaire. However, neither of them have the sole responslbility for coordlnating campus programs and their input did not conflict with the information requested in the actual study. These two individuals completed the questionnaire, timed their responses and met with the researcher to review the construction of the questions and overall format of the questionnaire.

Suggest lons were made as to the length of the questlonnalre, the clarity of directions, and the need for a budget report. Changes occurred as follows: (a) the format of the questionnaire was altered to shorten the length (e.g. two questions were merged into one, repetitious questions were eliminated); and (b) the directlons were written more succinctly. 
Several administrators in the Chancellor's Offlce reviewed and evaluated the questlonnaire in addition to the individuals selected for the pilot test. These individuals were past college specialists and therefore qualified to test out the questionnalre. They agreed with the results of the pllot test and approved the final changes. Following the approval of the questionnaire by the Chancellor's Office, DSP\&S coordinators and college specialists were notified of the forthcoming questionnaire at a state conference.

Cover Letter. The cover letter included endorsement from the Chancellor's Office, a description of the need and purpose of the questionnaire, a statement informing participants that they would receive a copy of the results, and the deadline for returning the questionnaire.

Malling the Quest lonnaire 8. Follow-Ue. The malling of the questionnaire included the cover letter, the questlonnaire, and a stamped, return-addressed envelope. Follow-up letters and additional copies of the questlonnalre were sent to colleges that did not respond to the initial malling.

Validity. Fox (1969) suggested that content validity was the strongest technique available to researchers using a questionnaire. He posited that true content validity occurs when there is a rational basis to the selection of the actual content which can be achieved through the 
researcher's knowledge of the literature and breadth of his/her own experience.

Information obtained from the Perkins VEA and a review of the Ilterature affected the development of the content of the questlonnalre. Each question written into the questionnaire resulted from the literature on special vocational programs for students with disabllities andor the actual document of the Carl Perkins VEA.

The pilot test examined whether or not each question adequately addressed the information sought and if the directions were clear and comprehensive. The researcher and college experts reviewed and examined these questions according to their knowledge of VEA and expertise in supervising vocational programs for students who are disabled.

Rellability. This study sought information of a descriptive nature. The information was submitted by Individuals who are experts in the fleld and well-qualified to provide these facts. The questionnaire was inltially sent to program administrators who then determined which individual on their campus was responsible for the vocatlonal services and or who best understood the college uses of VEA funds. There should be no reason why the data obtalned would change if requegted at a later date.

Fox (1969) proposed certain conditions to achieve high rellablllty, and described the utopla for reliability as 
such: "The researcher is seeking relatively certain information which the respondents have in their repertoire of responses, which is stable over time, and which involves dynamlcs whose components the researcher not only knows but can translate into instrument form" (p. 361-362). This study relled on the judgments of the experts, and to achieve a higher reliability rate conducted the following procedures:

1. Examination of portions of the services identified on the matrix with the budget reports.

2. Examination of the highest costs listed on question \#2 of the questionnaire with the budget reports.

3. Examination of the descriptions on VEA programs and projects with any brochures sent in.

4. A descriptlve review of the results with the purposes of the Perkins VEA.

\section{Selection of siteg}

The California community colleges consisted of single-college districts as well as multi-college districts. There were seventy districts throughout the state with a total of 106 colleges.

\section{Distrlets}

Flfty-seven of 70 districts participated in the evaluation of funds allocated to DSP\&S. An $81 \%$ rate was 
obtained by analyzing the budgets of all districts which utllized VEA funds during 1987-88. The research question that addressed the disbursion of VEA funds to districts Included the percentage of the portion of VEA funds for students with disabilities as compared to the total VEA Title II-Part A monies, the difference of VEA funding to DSP\&S funding provided to each district, and the allocation of VEA funds for services throughout the districts.

\section{Colleges}

Seventy-two colleges participated in the collection of data on services and programs by completing the questionnaire. This represented $69 \%$ of the California communlty colleges. Forty-one of these colleges were in single college districts and thirteen were in multi-college districts.

\section{Selection of Participants}

Questlonnaires were sent to all DSP\&S program administrators at 106 community colleges. Questionnaires were then distributed to the most appropriate individual within the colleges depending upon the size of the district. DSP\&S staff who completed the questionnaires included directors of departments, coordinators of DSP\&S, college specialists, and counselors. 
All participants from the DSP\&S held appropriate DSP\&S credentials and at least a master's degree level of education.

\section{Statistical Procedures}

\section{Methods}

Data from the VEA budget forms, DSP\&S allocations report and the questionnaire was tabulated by hand and systematically coded. Data was then entered into a VAX computer and processed by the statistical Package for Social Sciences (SPSS).

Research Question Number 1, How were the VEA funds allocated withln DSP\&S during 1987-88?

1. What percentage of the total VEA Title II-Part A, Basic Grants was allocated in each district to students with disabilities?

The data obtained to answer this question was gathered through the VEA budgets of 57 districts. Each budget report provided the total amount of VEA funding per district and the breakdown of separate funds allocated to the six target populations as defined by the Perkins VEA (see Definitions of Terms). The percentage of funding allocated to the "handlcapped" population was determined by dividing the total amount of Title II Part A monies by the portion of 
funds set aside for students with disabilities in each district.

2. What was the comparison of VEA funding for students with disabilities compared to funding allocated to each district for DSP\&S?

The Chancellor's Office report on the DSP\&S 1987-88 allocations was utilized to determine the amount of total DSP\&S funding allocated to each district. The total DSP\&S expenditures were then compared to the VEA funding amount gathered from the VEA budget reports and reported by percentages.

3. What was the distribution of VEA expenditures during 1987-88 for students with disabilities?

The VEA budget reports provided information on the total direct costs and the objects of expendltures during 1987-88. Total direct costs were products of teachers: salaries, supervisors' salaries, counselors' salaries, clerical salaries, instructional aides' salaries, other classified salaries, employee benefits, textbooks and other books, supplles, contracts (services), conferences and travel, contracts (rents), utilities and housekeeping, and equipment. The objects of expenditures consisted of basic skills special instruction, child care services, guidance and counseling, staff development, placement services and recrultment, transportation services, and administration. 
An example of such expenditures would be a teacher in a special vocational program for students who are physically handicapped and would be indicated as teachers' salaries in the basic skills instruction category.

Frequencles were calculated from the budget data and included: (a) the indlvidual sum of each subcategory (e.g. teachers' salaries in basic skill instruction), (b) the sum of each category in total costs (e.g. teachers' salaries), and (c) the sum of each category in the objects of expenditures (e.g. basic skllls ingtruction). The sum of direct costs was then matched with the sum of expenditures to verify that all dollar amounts were equivalent and coded in properly. For a final reliability check the total sum of funding was compared to the total amount of VEA Handicapped funds allocated to the distrlets.

Research Question Number 2, What programs and services provided for students with disabilities in California community colleges were funded by the Perkins VEA?

1. What activities and services that meet the requirements of VEA funding were provided to students with disablilities?

This question was addressed through a checklist and matrix in the questionnaire. Participants were requested in a matrix to ldent!fy the services provided at the college with the disability group who received the service. The 
following services were listed: basic skllls instruction, cooperative vocational education programs, career guidance and counseling, peer counseling, placement services, mobility assistance, special vocational programs, and remedial courses.

A checklist was utilized for participants to indicate (a) if they used VEA funds for interpreters for students with hearing impalrments, readers for students who are blind or partially sighted, and tutoring for students with learning disabilities; and (b) whether VEA funds were used for recruitment, acministration, in-service, and program coordination and supervision.

Frequencles were calculated on the number and percentages of participants indicating the provision of services in each subcategory for both the matrix and the checklist.

2. What categories of disabilities received services through VEA funding?

Data regarding this question was gathered through the matrix described in the research question above. Services correlated with the following disabilities: physical disabllity (vision impalred and mobility impaired), communication dlsability (speech impaired and hearing impaired), learning disability (learning disability and 
developmental disability), acquired brain injury, psychlatric disability, and substance abuse.

Information on the number of students according to their disability was requested on the questionnaire. Particlpants Indicated the number of students served at their colleges based upon the above disability categories. The total number of students and the mean number for all colleges in each category were calculated.

3. What percentages of colleges received funding under VEA Special Projects for exemplary programs and special projects?

Particlpants were requested to indicate on the questionnaire whether or not they applied and or recelved funding for VEA exemplary programs and special projects. The question regarding projects included checking the type of project designed as audiovisual materials, curriculum materials, resource guides, or reference materials. Erequencies were determined for the number and percentages of colleges who applied for funding and the number and percentages of colleges who received funding.

4. What models of emplayment were utilized in colleges that provided special vocational programs?

The questionnaire included a question for colleges that provlded special vocational programs through VEA funding on the type of model(s) utilized in these programs. The 
following models were ldentified: (a) the sheltered workshop; (b) the mobile work crew model; (c) the enclave model; (d) the supported work employment model; and (e) the unsubsidized work experience program. Definitions of each model were written in the questionnalre and a space for any other model that a college specialist wanted to identify was made avallable. Frequencies were computed on the number and percentages of colleges who utilized these models.

5. What was the composite of special vocational programs in colleges that identifled model or exemplary progr ams?

A separate sheet of colored paper was attached to the questionnaire for this information. Participants were requested to provide information on the following: program description, objectlves and outcomes of the program, program components, and products of the program. The number of college who submitted information was evaluated and the data was analyzed descriptively since limlted information was received.

Research Question Number 3. What areas of training did partlcipants receive regarding VEA funding and what areas of training did they identify as their current needs? 
1. In what areas have DSP\&S staff received the most training?

The questionnaire requested participants to check whether or not they have recelved training in any of the following areas: How to apply for VEA funding, VEA documentation, Approprlate uses of VEA funds, and the Carl D. Perkins VEA. Frequencies were calculated to determine the number of particlpants who received training in each category.

2. How did the partlcipants perceive the usefulness of their training?

Participants who received training in the above areas were asked to rate the training according to how they perceived its usefulness using a four-point likert scale. The Likert scale ranged from "of no use at all" to "very useful." Frequencies were used to compute the mean response and the number of participants who responded to this question.

A frequency on the number of particlpants who did not indicate recelving tralning but responded to this question was also calculated.

3. What areas of needs were ldentifled by the partlcipants for training?

The questionnaire asked repondents to rank on a four-polnt likert scale the areas of training they would 
like to receive in the future. The likert scale ranged from "definitely do not need" to "definitely need" and covered the categories of application, documentation, uses of funds, and the VEA. Frequencles were computed on the mean response and the number of participants who responded in each category.

4. What delivery methods were ldentlfied as the means for potential training?

Particlpants were requested to determine the delivery method they felt would be most approprlate for potential training. The options for delivery included district inservices, association-sponsored conferences, Iiterature, and or personal contact with others who utilize VEA funds. Frequencies were calculated on the number and percentages of partlcipants responding to the options available.

\section{Dissemination}

A statistical analysis, Interpretation of results, and recommendations were written in a report and submitted to the Chancellor's Office of the Speclally Funded Projects, Disabled Student Programs and Services, Cal ifornia Community Colleges in Sacramento. A copy of the results was made available to the participants of this study. 


\author{
CHAPTER FOUR \\ Analysis of The Data
}

Introduction

The purposes of this study were to examine the distribution patterns of VEA funding allocations within the California community college districts, to identify services for students with disabilities funded under VEA in each college, and to identify the disabllity groups who recelved these services. Data provided for these purposes was obtained from the 1987-88 budget allocatlons reports for districts and through a questionnaire sent to communlty colleges.

Fifty-seven district budget reports were utilized for this study, representing $81 \%$ of the California community college digtricts. Seventy-two college participants completed the questionnaire, representing $69 \%$ of the Cal ifornla community colleges.

Analysis of Budget Allocation Reports Research Question Number 1: How were the VEA funds allocated within the Disabled Student Programs \& Services (DSP\&S) during 1987-1988?

What percentage of the total VEA Title II-Part A. Basde Grants was allecated in each district to students with 
disabilitles? The data determining the ratio of VEA Handicapped Funds to the total VEA Basic Grants was calculated into four quartiles to examine whether districts met the Perkins VEA requirement that $10 \%$ of the monies be distributed toward the population of the handicapped. The budgets of 57 districts Indicated that the largest number of districts ( 31 ) utilized between $10-19 \%$ of their total VEA budget for students with disabilities, representing $54 \%$ of the districts (Appendix D). The second highest number of districts (16) utilized between 20-29\% of their funds, representing $28 \%$ of the districts. Table 1 illustrates the percentage of VEA Handicapped Funds to the total VEA budget by the number and percentages of districts.

Table 1

The Relat lonship of VEA Handicapped Funds

to the Total VEA Budget

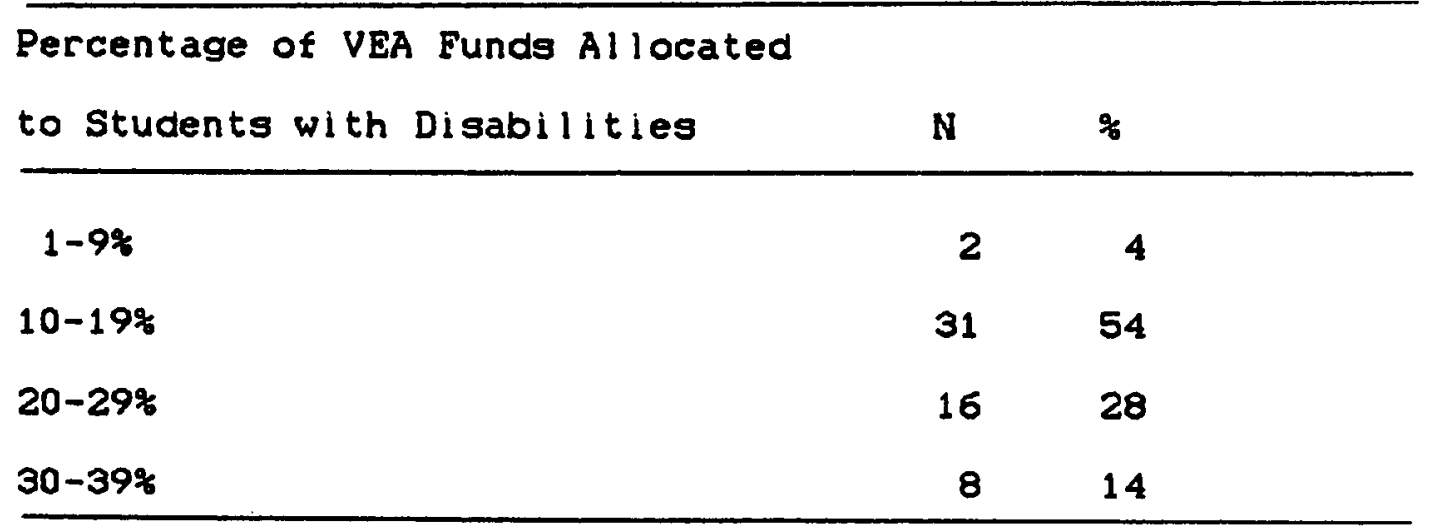


The 10\% requirement has been met in all but two districts, with $96 \%$ of the districts at or above this level. The average percentage (mean) of funding allocated to the population of the disabled was reported at $19.7 \%$.

What was the comparison of VEA funding for students with disabilitieg compared to funding allocated to each college for DSP8S? This study found that VEA funds included an additlonal $19.6 \%$ of revenue for DSP\&S programs and services throughout the state (Appendix D). It was reported that $51 \%$ of the districts expended 15-29\% over their DSP\&S allocations in VEA funds, as lliustrated in Table 2.

Table 2 .

The Relationship of VEA Handicapeed Funds

to DSP\&S Eunding

\begin{tabular}{lcc}
\hline Percentage of VEA Funds as & & \\
Compared to DSPS Funds & N & $\%$ \\
\hline & 18 & 32 \\
$1-14 \%$ & 29 & 51 \\
$15-29 \%$ & 8 & 14 \\
$30-44 \%$ & 2 & 4 \\
$45-59 \%$ & & \\
\hline
\end{tabular}

$\mathrm{N}=57 \quad$ Mean $=19.6 \%$ 
These results represent a significant amount of supplemental funding and are consistent with research that found that colleges Identifled VEA funds as additional revenue, second only to fund raising activities (Program Evaluation, 1987).

What was the distribution of VEA expenditures during 1987-88 for students with disabilities? The total VEA budget for 57 community college districts amounted to $\$ 17,173,667$. Within this total the amount of funds allocated to the VEA Handicapped Funds portion totalled $\$ 3,022,467$. The budget allocations for the VEA Handicapped Funds were analyzed based upon: (a) the direct costs, such as teachers' salaries, benefits, and equipment, and ( $b$ ) the objects of expendltures, such as basic skills instruction. counseling, and transportation (Appendix $D$ ).

The results of the data for direct costs revealed that the majority of funding $(66 \%)$ was allocated as follows: (a) $19 \%$ of the funding was allocated to teachers' salaries (\$581,160), (b) $17 \%$ allocated to counselors' salaries (\$510,992), (C) $16 \%$ to instructional aides' salaries (\$493,037) and (d) $14 \%$ for other classified salaries $(\$ 419,930)$. 
Figure 1 illustrates the amount of funas allocated by percentages. Twelve percent $(12 \%)$ of the budget proved insignificant in the areas of clerical salaries, textbooks. supplles, conferences and travel, cents, and utilities, and is indicated in figure 1 as miscellaneous funds.

\section{Eiqure 1. Allocations of Funds for Direct Costs.}

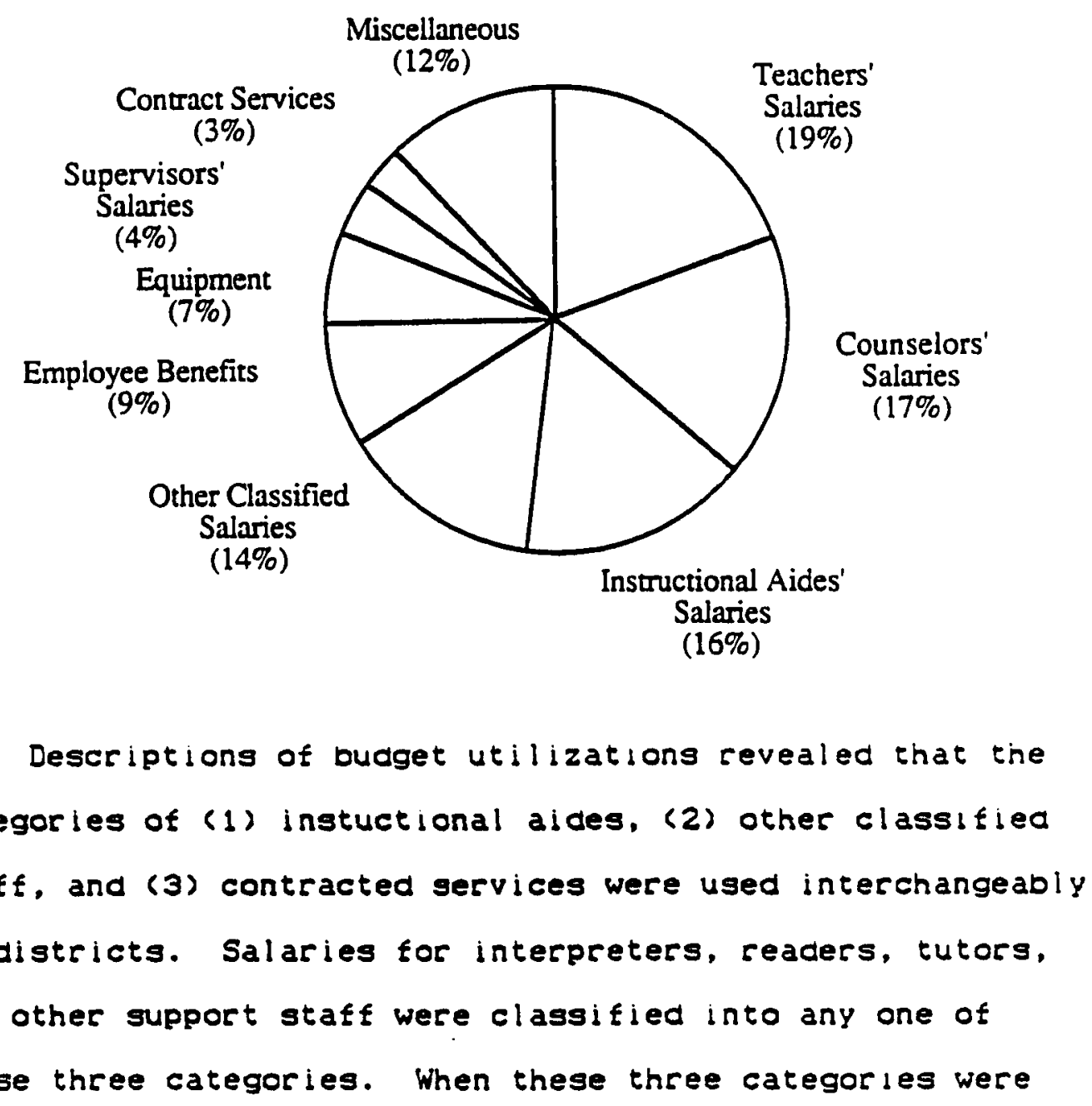


combined the amount totalled $\$ 1,000,000$. The funds allocated to this combined group constltuted the highest cost category, followed by teachers' salarıes, then counselors' salaries.

An examination of the budget utilizations reports revealed that teachers and support staff ce.g. Interpreters, readers, and tutors) salarles were funded at approximately 100\%. The reports also revealed that only partial amounts of counselors' salarles were supported by VEA.

In the area of objects of expenditures $67 \%$ of the funds provided financlal support for basic skills Instruction, totalling $\$ 2,013,739$. The cost for basic skills instruction included teachers' salaries and support staff salaries, as well as a portion of the employee benefit costs. Vocational guldance and counseling received the next highest allocation amounting to $\$ 746,279$, representing $25 \%$ of the total allocation. The least amount of money was allocated at $4 \%$ for administration $(\$ 114,563)$, 3\% for staff development $(\$ 90,483), 1 \%$ for placement services and recruitment $(\$ 30,806)$ and finally an Insignificant amount for transportation $(\$ 26,597)$. 
Elaure 2. Allocations of Funds for the Objects of

\section{Expendi tures.}

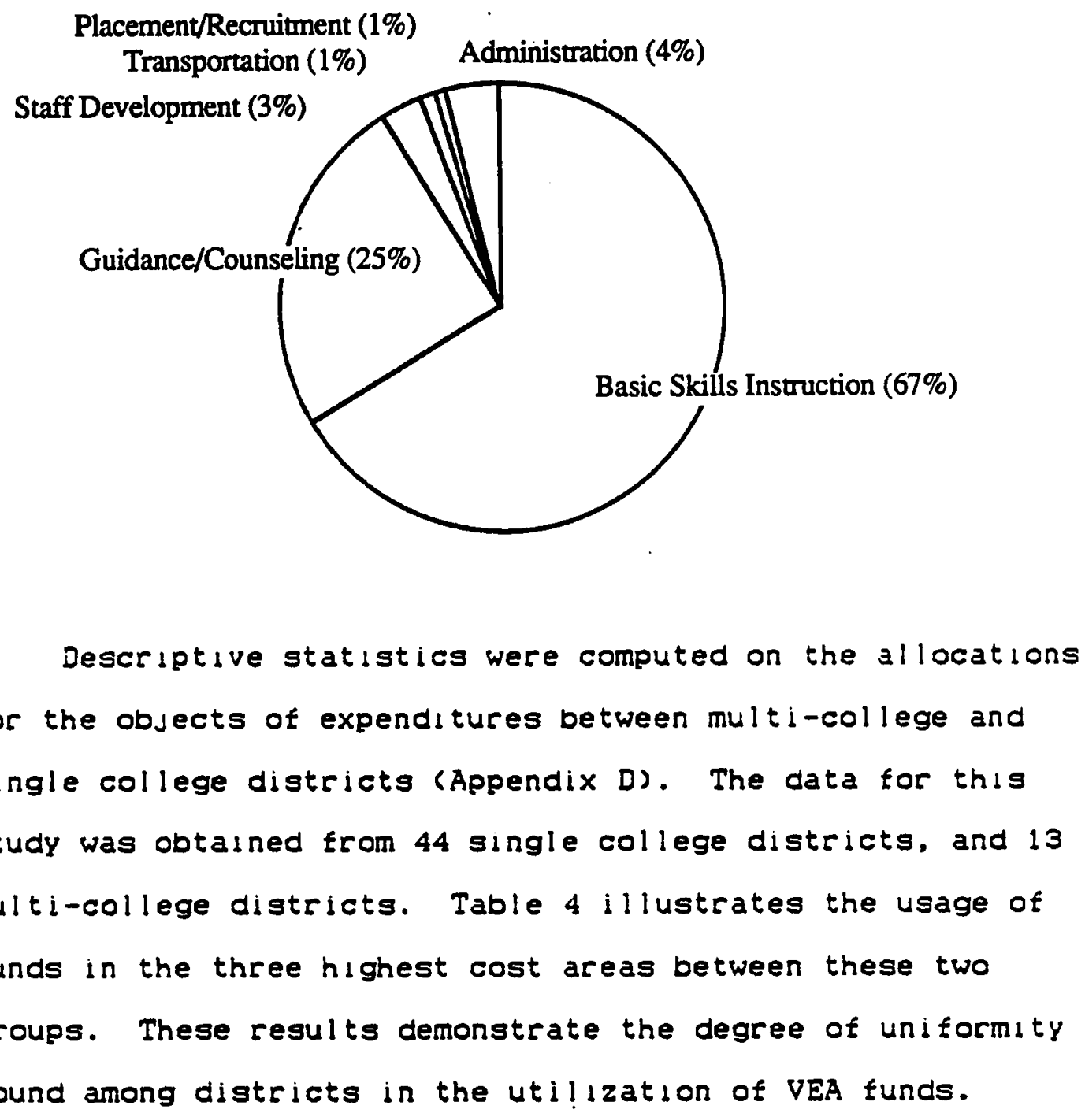


Table 3. Allocation of Oplects of Expenditures

by the Type of Distriat

Objects of Expendl tures

According to the Type of

Single College Multi-College

District

District District

Highest Costs

Basıc Skills Instruction

$\%$

Career Guidance \& Counseling

$66 \quad 68$

Adninistration

$23 \quad 27$

Administration $4 \quad 3$

\section{Analvsis of Questionnarce}

Research Question Number 2. What programs and services provided for student with disabilities in California community colleges were funded by the Perkins VEA?

What activities and services that meet the requirements of VEA tunding were provided to students with disabl lities? Data that answered this question was gathered from a matrix which requested participants to identity the services that their colleges utilized through VEA funding and the disability groups who received these services. 
The results indicated that career guldance and counseling was the most frequently offered service with $59 \%$ of the colleges providing services across all disability groups. Basic skills instruction was reported as the second most frequently offered service ( $50 \%$ ) across disability groups.

Table 4. The Frequency and Percentage of Colleges Providing Services Across All Disability Groups

\begin{tabular}{lcc} 
Services Provided To All & \\
Disability Groups & $\mathrm{N}$ & $\%$ \\
\hline Basic Skills Instruction & 36 & 50 \\
Cooperative Vocational Education & 14 & 19 \\
Career Guidance \& Counseling & 50 & 69 \\
Peer Counseling & 10 & 14 \\
Placement Services & 26 & 36 \\
Mobility Assistance & 19 & 26 \\
Special Vocational Programs & 9 & 13 \\
Remedial Courses & 34 & 47 \\
Recruitment & 23 & 32 \\
Administration & 18 & 25 \\
Program CoordinationiSupervision & 25 & 35 \\
\hline
\end{tabular}

$1=72$ 
Remedial courses were provided by $47 \%$ of the colleges, and placement services for completers were provided by $36 \%$ of the colleges across all disability groups. The least frequently provided services across disability groups included mobility assistance $(26 \%)$, cooperative vocational education programs ( $19 \%)$, peer counseling (14\%), and special vocational programs $(13 \%)$.

The results on management services provided by colleges revealed that $32 \%$ of the colleges utilized VEF funds for recrustment purposes, $25 \%$ for administration, and $25 \%$ for program coordination and supervision. This is consistent with VEA guidelines which stringently limit funding allocatıons for management usage, and lndicates that the majortty of colleges do not utilize VEA funds for these purposes.

The most frequently offered supplemental services $150 \%$ and over' provided to specific disability groups were reported as follows: (a) $64 \%$ of the colleges provided mobility assistance and $56 \%$ offered remedial courses to students with visual impairments, (b) $57 \%$ of the colleges provlded remedial courses for student with mobility Impalrments, (c) $53 \%$ of the colleges provlded remedial courses to students with health impalrments, (d) interpreters were provided by $50 \%$ of the colleges 
and remedial courses in $54 \%$ for students with hearing impalrments, (e) $69 \%$ of the colleges provided remedial classes and $60 \%$ provided tutors for students with learning disabilities, and $(f) 50 \%$ of the colleges provided remedial classes for persons with acquired brain injurles (Table 5 and Eigure 3 ).

Table 5. The Allocation of VEA Funds by Colleges for Specific Services to Students with Disabilities

\begin{tabular}{lll}
\hline Service & N & $\%$ \\
\hline Interpreters & 36 & 50 \\
Readers & 27 & 38 \\
Tutors & 43 & 60 \\
Recruitment & 23 & 32 \\
Administration & 18 & 25 \\
Program Coordination & 25 & 35 \\
$\quad$ & &
\end{tabular}

The following Figure ( 3 ) reports the percentages of colleges who utilized VEA funds for speciflc services to students with disabilities. This figure is represented by the matrix used in the questionnalre. 
Figure 3. The Percentages of Colleges Providing Services tc Spectfic Disability Groups

\begin{tabular}{|c|c|c|c|c|c|c|c|c|}
\hline $\begin{array}{c}\text { DISABILITY } \\
\text { CATECORY } \\
\end{array}$ & $\begin{array}{l}\text { BAstc } \\
\text { SKILIS } \\
\text { INSTRUC- } \\
\text { TICN }\end{array}$ & $\begin{array}{l}\text { COPPER- } \\
\text { PIVE VOC } \\
\text { ED PROG. }\end{array}$ & $\begin{array}{l}\text { ORESRR } \\
\text { GUID- } \\
\text { ANCE : } \\
\text { CONH } \\
\text { SEING }\end{array}$ & $\begin{array}{l}\text { PEER } \\
\text { COUT } \\
\text { SELING }\end{array}$ & 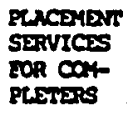 & $\begin{array}{l}\text { MoBrCITY } \\
\text { ASSISTENCO }\end{array}$ & 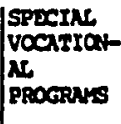 & $\begin{array}{l}\text { RSIISDIAI } \\
\text { COURSES }\end{array}$ \\
\hline $\begin{array}{l}\text { HYSICAL } \\
\text { ISABIEITY }\end{array}$ & \multicolumn{8}{|c|}{ 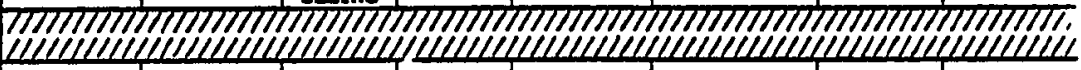 } \\
\hline $\begin{array}{l}\text { Vision } \\
\text { Impalced }\end{array}$ & $5 B$ & 24 & 80 & 15 & 44 & 64 & 15 & 56 \\
\hline $\begin{array}{l}\text { Mobilitiy } \\
\text { Impaized }\end{array}$ & 58 & 30 & 83 & 15 & 47 & 47 & 15 & 57 \\
\hline $\begin{array}{l}\text { Other } \\
\text { Heal th }\end{array}$ & 56 & 24 & 85 & 15 & $40^{\circ}$ & 46 & 14 & 53 \\
\hline $\begin{array}{l}\text { ORTIONI- } \\
\text { ATION } \\
\text { OISABILITY }\end{array}$ & \multicolumn{8}{|c|}{ 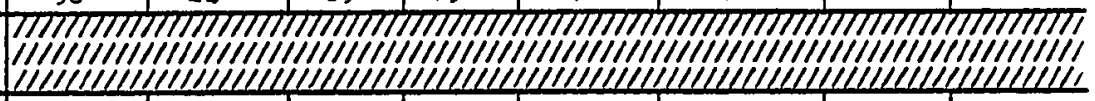 } \\
\hline $\begin{array}{l}\text { Speech } \\
\text { Inpaired }\end{array}$ & 43 & 21 & 68 & 13 & 32 & 10 & 8 & 44 \\
\hline $\begin{array}{l}\text { Hearing } \\
\text { Impaired }\end{array}$ & 57 & 29 & 82 & 18 & 46 & 13 & 8 & 56 \\
\hline \multicolumn{9}{|c|}{ IIIIIIIIIIIIIIIIIIIIIII) } \\
\hline $\begin{array}{l}\text { LGARAING } \\
\text { DISABLED }\end{array}$ & 78 & 28 & 86 & 18 & 43 & 15 & 14 & 69 \\
\hline \multicolumn{9}{|c|}{ IIIIIIIIIIIIIIIIIII0 } \\
\hline 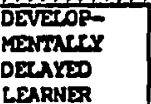 & 38 & 7 & 49 & 7 & 28 & 15 & 18 & 32 \\
\hline \multicolumn{9}{|c|}{ 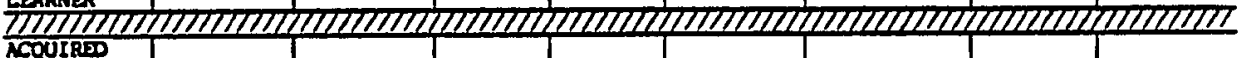 } \\
\hline $\begin{array}{l}\text { ACOUIRED } \\
\text { BRAIN } \\
\text { IKUURY }\end{array}$ & 61 & 19 & 75 & 14 & 36 & 47 & 19 & so \\
\hline \multicolumn{9}{|c|}{ 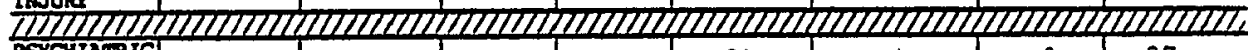 } \\
\hline $\begin{array}{l}\text { PSYCHIATRIC } \\
\text { DISABILITYY }\end{array}$ & 31 & 8 & 43 & 11 & 21 & 4 & 9 & 27 \\
\hline & IIII & IIII & 7772 & 7112 & 211 & 217 & 2112 & 2112 \\
\hline SUESTANCE & 26 & 11 & 39 & 11 & 19 & 3 & 7 & 24 \\
\hline
\end{tabular}

In conclusion the results of this matrix indicated that colleges most frequently utilized VEA funds to provide career guldance and counseling across all disability groups (69\%). The budget reports indicated that $25 \%$ of the total amount of VEA funding was allocated to supplement 
counselor's salaries. One of the main purposes of the VEA was to provide assistance and support to students with disabilities so that they gain access into regular vocational programs. The law stated that all students enrolled in vocational programs would recelve "guidance, counseling and career development activities" and "counseling services designed to facilitate the transition from school to post-school employment and career opportunities" (Section 204, Carl Perkins Vocatıonal Education Act, 1984). This study found that community colleges are complying with federal regulations to provide counseling and guidance as reported in the allocations of funds and by the individual college reports of services and activities.

Basic skills instruction was reported as the second most frequently offered service provided by colleges through VEA funds. Basic skill ingtruction in the community colleges included such programs as Engl ish classes for students who are hearing impaired, computer instruction for students with learning disabilites preparing to enter the computer field, and cognitive retraining for the brain injured. These classes enhance student participation in regular vocational education programs by preparing them to 
meet the prerequisites for these programs and strengthening their skills necessary to succeed once encolled.

Specific supplemental services were rated high for students with mobility, visual, hearing and speech impalrments, as well as students with learning disabilities and acquired brain injuries. Some of these services included mobility assistance, interpreters, remedial courses, and tutors. Fewer supplemental services were provided to students with developmental disabilities, psychiatric disabilities, and substance abuse difficulties.

\section{What categories of disabilities recelved services} throuah VEA fundina? The matrix presented above indicated that the majority of colleges provided services to students with physical disabilities (vision, mobility, and health lmpalred), communication disabilities (speech and hearing impaired), and learning disabilities. A total of 9,296 students with disabilitles received services under the VEr. budget for 72 colleges (Appendix D). The highest number of students who recelved services reported by subcategory was 2,910 students with learning disabilities, followed by 2,418 students with mobility impalrments (Flgure 5). The number of students who received services under VEA are as follows: 
Elaure 4. Number of Students Served by VEA Funds Based Upon Disability Groups ( $N=9296)$.

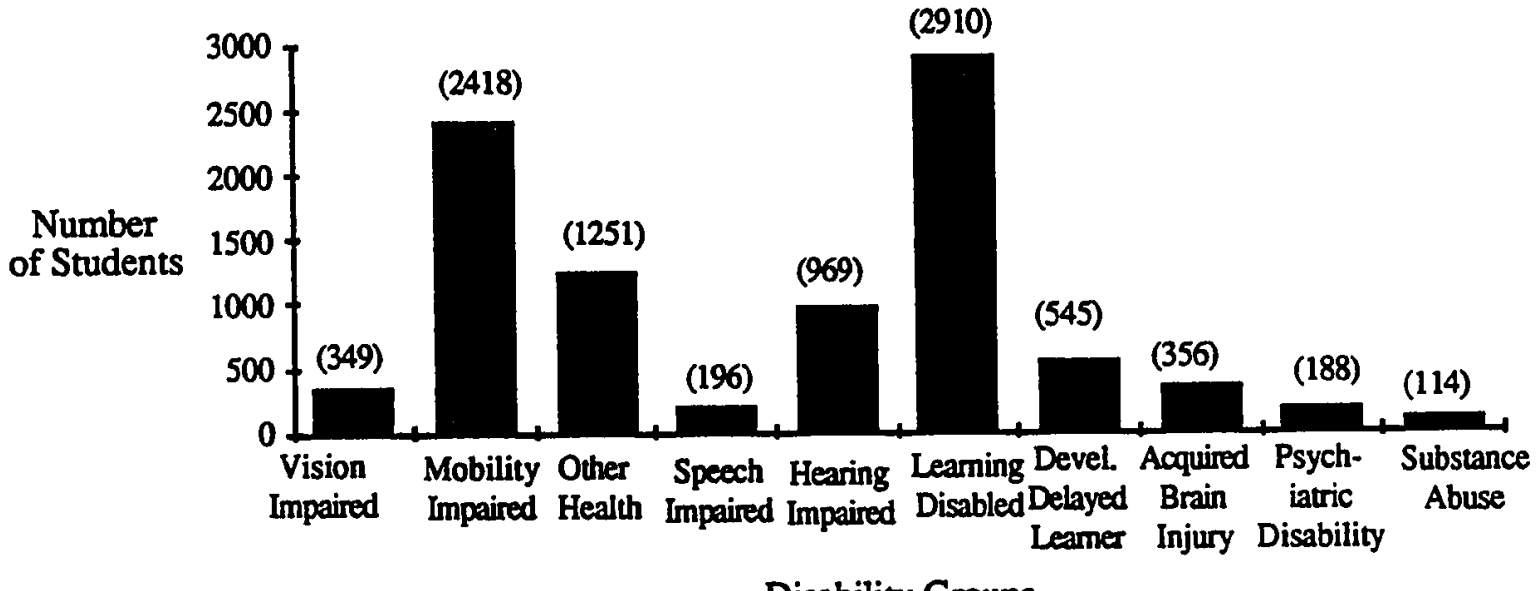

Disability Groups

\begin{abstract}
When the subcategories of mobility impaired, visually impalred and other health impalrments were combined into the category of physical disabilities and the subcategories of speech impaired and hearing impaired were combined into communication disabilities the data was examined by the category of disability. The percentage of students served by disability categorles occurred as follows: $43 \%$ of students were physlcally disabled, 31\% were learning disabled, $13 \%$ of the students had communication disabilities, 6\% were developmentally disabled, $4 \%$ had acquired brain injuries, $2 \%$ had psychiatric disabilities, and $1 \%$ were substance abusers.
\end{abstract}


A breakdowr of disability groups indlcated that the categorles of disabilities that recelved services through the VEA were consigtent with student demographies within the community college system. Figure 5 illustrates the comparison of student encoliment in the community colleges with students receiving VEA service according to disability groups. This figure shows that as compared to student enrollment, students with disabilties recelving funds under VEA and DSP\&S appear proportionate.

Eicure 5. Comparison of Student Enrollment to the Number of Students Receiving Services under VEA.

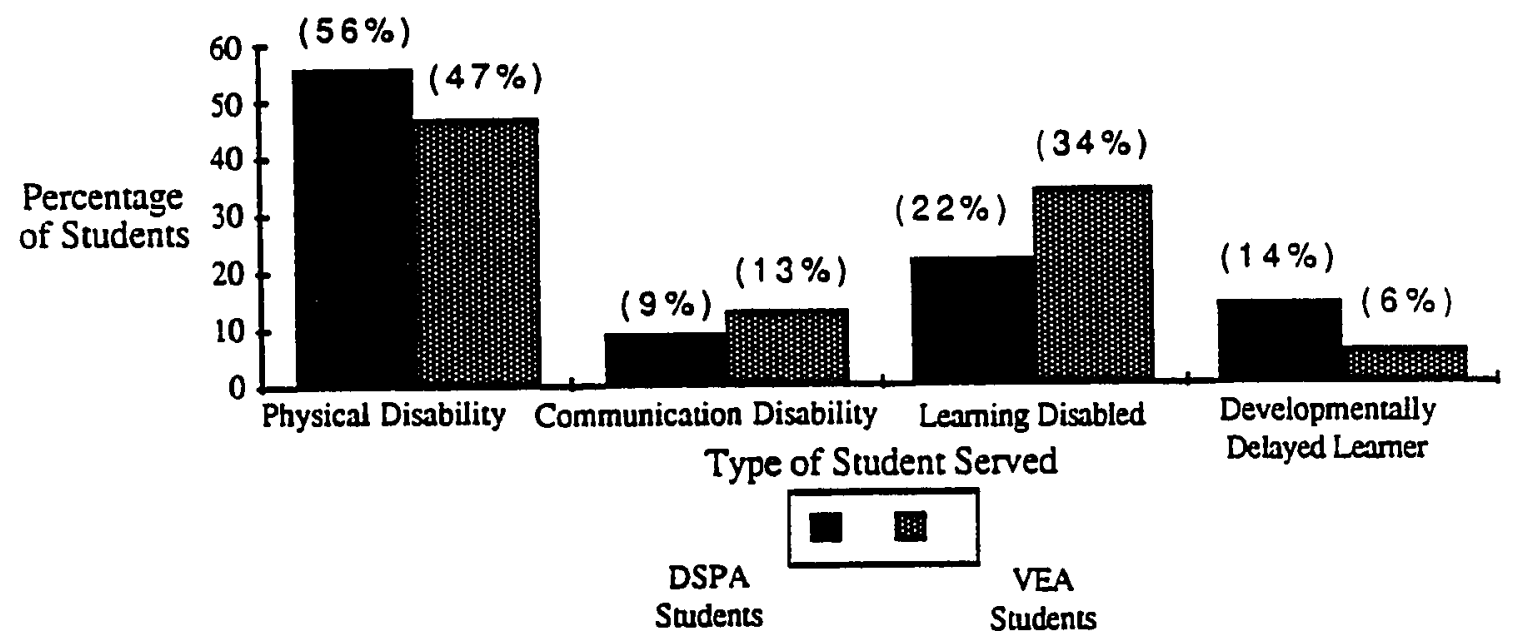

Data was not available for comparing the disability groups of acquired brain injury, psychlatrle disability and substance abuse. Students with acquired braln injurles 
represent a recent category of students served by the community colleges, and therefore little research has been developed regarding this category group. A lack of ldentification of students with psychlatric disabilities and substance abuse problems under Title $V$ of the California Code which governs the operations of the community colleges may be the cause for these categorles to receive the fewest services. The community college system does not presently identify these categorles of disabilities, resulting in a lack of DSP\&S funding for students under both classifications. Therefore limited services exist for these populations.

What percentage of colleges received funding under VEA Special Projects for exemplary programs and special projects Eight percent $(8 \%)$ of the colleges participating in this study reported that they received VEA exemplary funds for model programs or projects. This totalled only six colleges.

Of these six colleges one college applied and recelved VEA funds for a model program; one college applied and received funding for a model program and audiovisual materlals; one college applied for and received funds for audiovisual materials and curricula materlals: one college applied and recelved funds for a model program, audiovisual 
materials, and curricula materials. Two colleges did not report applying for the funds, but one of these colleges recelved funding for a model program and the other college recelved funding for a model program, curricula mater resource guide, and reference materials.

Table 6. Number of VEA Exemplary Proarams and Projects

\begin{tabular}{|c|c|c|c|c|}
\hline \multirow[b]{2}{*}{ Programs and Projects } & \multicolumn{2}{|c|}{ Appl sed For } & \multicolumn{2}{|c|}{ Recelved } \\
\hline & $\mathbf{N}$ & $\%$ & $\mathbb{N}$ & $\%$ \\
\hline Model Program & 3 & 4 & 4 & 6 \\
\hline Audiovisual Materials & 3 & 4 & 2 & 3 \\
\hline Curriculum Materials & 2 & 3 & 3 & 4 \\
\hline Resource Guides & 0 & 0 & 1 & 1 \\
\hline Reference Materials & 0 & 0 & 1 & 1 \\
\hline
\end{tabular}

This information revealed that not even $1 \%$ of the colleges surveyed recelved VEA exemplary monies in any one category. It also reported that two of these colleges did not actually apply. This indicates that colleges may not be aware of special exemplary VEA monles or may not recelve the information in the DSP\&S offices. Two specific comments 
were made on the surveys, one stated that they needed more Information on VEA exemplary monies and the other reported that by the time the application for exemplary programs filtered out of the vocational education office within the district and into DSP\&S, there wasn't enough time to complete an application.

What models of employment were utilized in colleges that provided spectal vocational proarams? Fifteen percent ( $15 \%)$ of the participants identifjed utilizing one or more models of employment in their colleges which accounted for only eleven colleges.

One college identified the supported employment model and unsubsidized work experience in its program, three others identified supported employment models, three utilized unsubsidized work experience, and four ldentitied using sheltered workshops. No colleges reported utilizing the work/mobile crew model or enclave. Table 7 reports both the number and percentages of colleges who indicated utilizing models of employment. 
Table 7. Celleges Using Specific Service Delivery

Models for VEA Supported Special Vocational Programs.

Delivery Models Utilized in

VEA Supported Programs

$\mathbb{N} \%$

Work/Mobile Crew

$0 \quad 0$

Enclave

$0 \quad 0$

Supported Employment

46

Unsubsidized Work Experience

46

Shel tered Workshop

4

6

Since only $13 \%$ of the colleges surveyed reported offering special vocational programs for students with disabilities the data received on models of employment was considerably low. The disability groups that most frequently received services in special vocational programs were identified as the acquired brain injury recelving services in $19 \%$ of colleges and the developmentally delayed learner in $18 \%$ of the colleges. With such limited data it is difficult to determine the association between models of employment and the population groups served.

What was the composite of special vecational programs in colleges that identified model or exemplary programs? 
Five colleges $(.06 \%)$ responded to the attached survey requesting information on model programs. Of the five, three colleges provided special vocational programs for students with disabilities with an emphasis on career counseling, job placement, and work training. The remaining two colleges reported specialized instruction: one offered computer assisted vocational/career instruction, and the other provided a program in vocational exploration. This study found that $15 \%$ of the colleges surveyed indicated that they utilized VEA funds for special vocational programs and only $8 \%$ of the colleges received exemplary funds for model programs. These results affected the data recelved on the composites of special programs.

Besearch Question Number 3: What areas of training did participants receive regarding VEA funding and what areas of tralning did they identify as current needs?

\section{In what areas have DSP\&S staff recelved the most} training? Four areas of training were listed for participants to indicate whether or not they received training. These included: (1) how to apply for VEA funding, (2) VEA documentation, (3) appropriate uses of VEA funds, arid (4) the Carl Perkins VEA. 
The largest number of participants (29) indicated recelving training in the area of VEA documentation, followed by appropriate uses of VEA (28). Fewer responses were indicated in the areas of How to apply for funding (23) and the Carl Perkins VEA (19).

More than half $(60 \%)$ of the participants did not ind lcate that they received any training regarding the VEA.

Table 8. The Numbers and Percentages of Cellege

Participants Who Received Training Related

to VEA Funding

\begin{tabular}{lll}
\hline Area of Training & $\mathrm{N}$ & $\%$ \\
\hline & & \\
How to Apply for VEA Funding & 23 & 32 \\
VEA Documentation & 29 & 40 \\
Uses of VEA & 28 & 39 \\
Carl Perkins VEA & 19 & 26 \\
\hline
\end{tabular}

How did the participants perceive the usefuiness of their tralning? Overall the responses toward the usefulness of tralning were found positive. Particlpants were requested to indicate the usefulness of VEA training by completing a four-point Likert scale. The degrees of 
response were: $1=0$ no use at all, 2=somewhat useful, $3=u s e f u l$, and $4=v e r y$ useful. In the areas of VEA documentation and the uses of VEA funds the mean scores were 3.0. indicated that training in these areas was reported useful. In the areas of how to apply for VEA funding and the Carl Perkins VEA the mean scores were only slightly lower with 2.8 and 2.7 respectively. Table 7 illustrates the responses received by participants who recelved training.

Table 9. The Usefulness of VEA Related Training Recejved by Participants

\begin{tabular}{lll}
\hline Arsa of Training & $\mathrm{N}$ & Mean \\
\hline & & \\
How to Apply for VEA Funding & 15 & 2.9 \\
VEA Documentation & 28 & 3.0 \\
Uses of VEA & 25 & 3.1 \\
Carl Perkins VEA. & 15 & 2.7 \\
\hline
\end{tabular}

\section{Responses:}

$1=0$ No Use At All

2=Somewhat Useful

$3=$ Use ful

$4=$ Very Useful 
What areas of needs were identified by the participants for training? Participants were requested to indicate whether or not they needed training in certain areas by indicating the degree of need on a four-point likert scale. The degrees of response included: $1=$ definitely do not need, $2=$ may need, $3=1$ ikely to need, and $4=$ definitely need. A need for training was indicated in the areas of VEA documentation (2.7), the uses of VEA (2.6) and the Carl Perkins VEA (2.6). In the area of how to apply for VEA, participants did not indicate a need for training (2.2).

Table 10. Areas of Training Needs As Reported by Participants

\begin{tabular}{lll} 
Area of Training & $\mathrm{N}$ & Mean \\
\hline & & \\
How to Apply for VEA Funds & 53 & 2.2 \\
VEA Documentation & 46 & 2.7 \\
Uses of VEA Funds & 47 & 2.6 \\
Carl Perkins VEA & 49 & 2.6 \\
\hline
\end{tabular}

Responses:

$$
\begin{aligned}
& \text { 1=Definitely Do Not Need } \\
& \text { 2=May Need } \\
& 3=\text { Likely to Need } \\
& 4=\text { Definitely Need }
\end{aligned}
$$


What del ivery methods were ident ifled as the means for potential training? Participants of this study indicated that the district inservice would best assist them in training ( $56 \%)$. Most participants did not perceive assoclation-sponsored conferences, literature, or personal contact with college specialists as possible methods for training. The method of district inservice was the most positive response noted.

Since the information item requested on the questionnaire was not ranked, particlpants were able to check as many responses as possible. Following àre the results of this data.

Table 11. Methods Participants Prefer for the Deluery of Training

Method

District Inservice

Association-sponsored Conferences

Literature

Personal contact with college specialists
$\mathrm{N} \quad \%$

$40 \quad 56$

$29 \quad 40$

$29 \quad 40$

$23 \quad 32$




\section{Conclusion}

This study indicated that the Califoria community colleges have been in compliance with the regulations of the Carl Perkins VEA. The VEA stipulated that $10 \%$ of the total budget must be allocated to the population labelled as "handicapped." This study demonstrated that $54 \%$ of the districts utilized between 10-29\% of the VEA funds for students with disabilities, with an additional $28 \%$ ut lilizing between $20-2,9 \%$ of their funds for this population.

Research has proven that VEA funds are critical to the development and maintenance of programs, for the provision of ongoing supplemental services, and the inclusion of all persons into regular vocational education programs. This study reported that $51 \%$ of the districts supplemented the 16 DSP\&S budget by $15-29 \%$. This funding has provided additional funds for teachers, counselors, and support staff for basic skill instruction, vocational guldance and counseling, and supplemental services.

The data on funding allocations was derlved from district budget and utilization reports. This data Indlcated that the majority of funding was allocated to: (a) support staff salaries for mainstreamed vocational classes, (b) teachers' salaries for basic skills instruction, and (c) partial salaries of counselors to provide vocational 
guidance and counseling. The data on services and activities provided by these funds was obtained through a questionnaire. The results of the questionnalre indicated that vocational guldance and counseling was the most frequently provided service followed by baslc skills instruction.

The majority of colleges provided VEA services to students with physical disabilities, communication. disabilities, and learning disabilities. Fewer colleges reported providing services to students with acquired braln Injuries, developmental disabilities, psychiatrla disabilities, and substance abuse difficulties. These results appeared consistent with present services provided throughout DSP\&S in the community colleges.

Less positive responses were noted in the analysis of the data that examined VEA exemplary programs and projects, special vocational education programs with models of employment, and the composite of special vocational programs. Thirteen percent $(13 \%)$ of the colleges provided special vocational programs across all disability groups. Only 8\% of the college participants who responded to the questionnaire reported receiving special exemplary monies for either model programs or projects. As a result of such a limited number of programs, the data obtained regarding 
the models of employment and the composite of programs was insignificant.

The areas of training represented a positive trend, with the majority of participants reporting that the training they received was useful. Limited numbers of participants indicated that they recelved training yet responded positively about the training received. A need for training was suggested in the areas of VEA documentation, the uses of VEA, and the Carl Perkins VEA. In the area of how to apply for VEA participants did not indicate a need. DSP\&S staff reported that when further training is needed, the district inservice would best accommodate this need.

\section{Discussion of Findings}

An analysis of the budget utilization reports, a breakdown between multi-college and single college districts, and the descriptive statistics from the budgets and questionnaires revealed very little diversity in the allocation of funds and the services provlded to students with disabilities. This study intended to examine whether any differences occurred between colleges and districts and unexpectedly found little variation in the uses of funds. 
Multiple statistics were found to be lnsigniflcant and unnecessary due to this uniformity.

A separate survey was attached to the questionnalre to receive additional information on VEA innovative and exemplary programs and projects. The researcher expected to receive data on special vocational programs and projects that could be shared with DSP\&S coordinators and college specialists in an attempt to encourage networking and information sharing that would contribute to the inception of new innovative programs and the improvement of existing ones. It was unexpected that only $19 \%$ of the colleges utilized VEA funds for special programs, and that so few colleges received VEA exemplary funding. The review of literature reported that community colleges operated on the premise of diversity, yet this study found that very little diversity existed in the vocational education services provided to students with disabilities.

Eifty-seven districts participated in the budget findings. Twelve district budgets were not available for analysis, five of them from multi-college districts and seven from single college districts. The data received was significant at the $70 \%$ level and the researcher feels that the missing $30 \%$ would not greatly effect the results. 
Seventy-two colleges participated in the analysis of the questionnaire $(69 \%)$. The questionnaires were completed by DSP\&S coordinators, college specialists, and counselors. A high reliability rate can be expected for the following reasons: (a) the information was of a descriptive nature, (b) DSP\&S program administrators received the questionnalre and disseminated it to the most appropriate person at their site regardless of position title, (c) there was a $69 \%$ response rate, (d) the results reported consistent, uniform responses among colleges and (e) the services ldentified from the questionnalres and the costs for services as indicated by the budgets were consistent.

In the area of training approximately $30 \%$ of the participants of the study did not respond to some of the questions. Some participants (10) who did not report recelving training responded to the ratings of training and some participants (at least 8 ) who responded to receiving training did not answer the questions on the degree of usefulness of the training. It is also possible that participants who did not indicate receiving training did not respond to the future needs requested. This information suggested a flaw in the instrument. It was found that the questionnalre presented two problems: (a) the area for checking whether or not a participant recelved training was 
placed incorrectly in the questionnalre, corresponding to the question on future training needs when it should have been placed next to the ratings for the training, and (b) since the term "training" was not defined it may have been interpreted differently by participants.

Additionally in the area of training, a checklist was available for participants to identify possible options for future training. This checklist was not ranked and participants were able to check any of the options. This information then did not allow the researcher to ldentify the extent to which one option may be more desirable that another : 
CHAPTER FIVE

Conclusions, Implications and Recommendations

\section{Conclustons}

The purposes of the study were: (a) to examine the distribution patterns of VEA funds within the community college districts, (b) to identify services for students with disabilities funded by the VEA in each college, and (c) to ldentify the disabllity groups who recelved these services. Data was collected through the examination of records and the development of a questionnalre.

Eifty-seven distrlct budget reports were utilized for this study, representing $70 \%$ of the California community college districts. Seventy-two college participants completed the questionnalre, representing $69 \%$ of the California community colleges.

This study indicated that the Califoria community colleges have been in compliance with the regulations of the Carl Perkins VEA. The VEA stipulated that $10 \%$ of the total budget must be allocated to the population labelled as "handicapped." This study demonstrated that $54 \%$ of the districts utilized between $10-29 \%$ of the VEA funds for students with disabilities, with an additional $28 \%$ utilizing between $20-29 \%$ of their funds for this population.

Research has proven that VEA funds are critical to the development and maintenance of programs, for the provision 
of ongoing supplemental services, and the inclusion of all persons into regular vocational education programs. This study reported that $51 \%$ of the districts supplemented the 5 DSP\&S budgets by $15-29 \%$. This funding has provided additional funds in the areas of support staff salarles for mainstreamed vocational classes, teachers' salaries for basic skills instruction, and partial salarles of counselors to provide vocational guidance and counseling.

Thls study identifled the special services funded under VEA provided by California community colleges to students with disabilities. The services provided by VEA included career guldance and counseling in $69 \%$ of the colleges and basic skills instruction in $50 \%$ of the colleges across all disabllity groups. Fifty percent $(50 \%)$ of the colleges surveyed provided mobility assistance to students with visual impairments; interpreters for students with hearing impairments; tutors for students with learning disabilities; and remedial courses for students with learning disabilities, hearing impairments, and physical disabilities (including vision, mobllity and other health categorles). The services less frequently provlded included placement services for completers available in only $36 \%$ of the colleges, cooperative vocational education programs $1014 \%$ of the colleges and peer counseling in $10 \%$ of the colleges. The majority of colleges provided VEA services to students with physical disabilities, communication 
disabilities, and learning disabilities. Fewer colleges reported providing services to students with acquired brain injurles, developmental disabilities, psychiatric disabılities, and substance abuse difficulties. These results appeared consistent with present services provided throughout DSP\&S in the community colleges.

The data collected regarding special programs funded under VEA examined: (a) the numbers of colleges providing special programs, (b) the percentages of exemplary programs and special projects, (c) the composites of model programs, and (d) the number and types of models of employment utilized in these special programs. The results revealed that $13 \%$ of the colleges provided special vocational programs across all disability groups. Only $8 \%$ of the college participants who responded to the questionnalre reported recelving special exemplary monies for el ther model programs or projects. As a result of such a limited number of programs, the data obtained regarding the models of employment and the composite of programs was insignificant.

In the area of training limited numbers of participants (less than $50 \%$ ) indicated that they received training yet responded positively about the training they received. A need for tralning was suggested in the areas of VEA documentation, the uses of VEA, and the Carl Perkins VEA. In the area of how to apply for VEA participants did not indlcate a need. DSP\&S staff reported that when further 
tralning is needed, the district inservice would best accommodate this need.

\section{Implications}

The results of this study indicate that the majority of funds are set aside to ensure accessibility of students with disabilities into regular mainstreamed programs. Funding has been utilized by the community colleges to provide support staff, counselors, and teachers, and to offer the necessary accommodations and support services for students with disabilities to participate in regular vocational education programs. The implications of these results Impact two areas of vocational education: (a) regular vocational education programs and (b) special vocational education programs.

Reqular Vocational Education Procarams

This study reported that VEA funding has been utilized for students with disabilities to participate in the initial processes of vocational training. Monies were allocated for the preparation of students (basic skills instruction, career guidance and counseling, remedial courses) and the participation of students into regular vocational education programs (interpreters, tutors, mobility assistance). Funding was not utilized for participation in.cooperative vocational education programs, placement services for completers, and evaluation of services. The study also 
ldentifled a lack of the utilization of models of employment for students with disabilities, which involves the training of students on the job. These usages of funds indicate that the majorlty of funds are utilized for vocational planning, remedial and basic skills instruction, and regular vocational training classes. These funds were not utilized by the majority of colleges for completion of the vocational training process: job placement and retention or follow-up services and evaluation.

While colleges may be investing a high amount of funding into the preparation and enrollment of students in mainstreamed regular classes, they are not providing placement services for students who complete these programs. Only $36 \%$ of the colleges reported utilizing VEA funds for placement services for completers. This is consistent with the review of literature that reported that only $36 \%$ of 39,376 students in Californla community colleges recelved any specialized job placement and only $16 \%$ of the colleges reported providing job placement specific to students with disabilities (Sampson, 1984).

The Community College Occupational Programs Evaluation System (COPES) is the California community colleges attempt to evaluate these services. The COPES provides a subsystem on the evaluation of services provided to students with disabilities. This evaluation system does not evaluate the number of students enrolled in programs with the number of 
students who complete vocational education programs, the number of students who are placed into jobs following completion of these programs, or the retention rate of students placed into employment.

Therefore, while this study identifled the services provided by VEA funds, the community colleges may not know to what extent these programs are effectively preparing students for work, whether they are successfully placing students into employment, or whether or not students maintain a high retention rate on the job.

\section{Special Vocational Prearams}

This study found that few colleges provided separate vocational programs for students with disabilities. The majority of disability groups recelving services through VEA funds included students in the physical disability, communication disability, and learning disability categories. Services for students with acquired brain injuries, developmental disabilities, psychiatric disabilities, and substance abuse difficulties were extremely limited.

The most frequently offered services related to the preparation and participation of students with disabilities Into regular vocational education programs thereby limiting the services available for students unable to attend these programs. This study reported (a) a significant lack of separate programs for students with disabilities, (b) a lack 
of programs for students of certain disability groups, (c) a lack of models of employment utilized in vocational training, and (d) a lack of VEA innovative, exemplary programs.

The review of literature reported that most adults with disabilities recelved little vocational or career education. It stressed the need for additional training and services during the adult years, and documented a high unemployment rate of persons with disabilities. The literature concluded that not only do persons with disabilities iace attitudinal barciers from employers but that they often lack the necessary skills to competively meet the work force. This study revealed that VEA funds limit the availability of programs for students with disabilitıes and it is not known whether students are adequately prepared for the working world.

It must be emphasized however that VEA funding is on!y one source of revenue for vocational education and supplemental to DSP\&S funds. It must also be understood that this study does not suggest that funds should not be utilized for regular vocational education. It does however posit that more diversity may be needed to meet the vocational needs of all groups of persons with disabllities. 


\section{Summary}

The review of literature suggested that community colleges are the greatest single provider of postsecondary education for students with disabilities and that the majority of persons with disabilities enter community colleges for vocational purposes. It also reported that community colleges on the whole pride themselves in their diversity and their ability to meet the nontraditional student. Yet, this study demonstrated that the community colleges were not diversified in their provision of vocational education for students with disabilities.

The study revealed that VEA funds were consistent in all districts, services were uniform, targeting only specific disability groups, and providing only a limbted number of specialized programs. This uniformity and lack of diversity may be a product of: (a) the process of application for VEA funds, (b) the excess cost factor, and (c) staff training and development. Application for VEA Funds

The Vocational Education Unit of the Callfornia Community Colleges, Chancellor's Office is responsible for the evaluation of VEA applications and the allocation of funds. It is in this office that the determination for the utilization of funding will effect all specific populations of students targeted under VEA. The Vocational Education Unit will determine the distribution of funds for the direct 
costs and objects of expenditures. The distribution of funds for programs for students with disabilities will occur without the expertise and input of the Disabled Student Services Specially Funded Programs of the Chancellor's Office. This lack of involvement of DSP\&S may account for the lack of diversity noted in programming and services provided by VEA funds to students with disabilities.

It is possible that since the availability of potential VEA funding is announced to the offices of vocational education at the state and district levels and not directly to the DSP\&S offices, the majority of districts have not been aware of the availability of exemplary funds for special programs or projects. This lack of awareness may account for the 1 imited number of exemplary programs available to students who are disabled.

\section{Excess Cost Factor}

The Carl Perkins VEA unlike previous vocational education acts required districts to meet the excess cost formula for the operation of separate vocational programs. The old act paid $50 \%$ of the total cost of separate programs while the current act insisted that only $50 \%$ of the cost of services which exceed the average per-pupil expenditures for comparable regular vocational education services would be paid. It was suggested that this change could result in the loss of programs in a number of states (Worthington, 1985). This study does not examine funding changes, but it does 
report that few separate programs for students with disabilities are funded under the current VEA. Staff Training and Development

Less than $50 \%$ of the participants of this study reported receiving training in VEA funding. These particlpants are the DSP\&S staff responsible for the administration and implementation of VEA programs and services. A need for training was reported in the areas of the Carl Perkins VEA and the appropriate uses of VEA funds. A lack of knowledge on these topics may account for the uniformity of services provided by VEA. Since these funds are federally supported and strict in accountability, DSP\&S staft who have not had sufficient training may be conservative in their implementation of activities and services.

It is also possible that the lack of models of employment utilized in special programs may be a result of the lack of training for staff.

\section{Recommendations}

Recommendations at the Federal Level

The history of vocational education depicted a reliance on federal legislation and funding for the development, maintenance, and expansion of vocational' education programs and services. Federal aid and support ensured that certain standards and speciflcations for programming would be 
embodied into the advancement of vocational education within our country. The Carl Perkins Vocational Education Act created ensurances that all persons would have equal access to vocational education, and persons with disabilities were one of six populations targeted to recelve specific funds for program accessibility. The funding allocated to this population, while small, has encouraged and provided for participation in regular vocational education programs. This study reported the usage of funds within the Callfornda communtty colleges and the services and activities that responded to this source of revenue. The results imply that adults with disabilities are receiving vocational guidance and counseling, supplemental services, and skill instruction, all of which prepare students for the successful integration into vocational education programs. The threat of federal cutbacks in all areas of vocational services alarms the field of vocational education. The loss of funding and the loss of federal mandates to provide for the education of persons with disabilities concerns leaders in the field of special education. The appropriateness of services and the demand from varied groups of persons with disabilities for these services were evident from the results of this study. With the upcoming reauthorization of the Carl Perkins VEA the following recommendations are made at the federal level: 
1. the continuation of federal mandates for the inclusion of adults with disabilities into vocational education programs.

2. the provision of funding to provide vocational guidance and counseling, supplemental services, and basic skill instruction for persons with disabilities.

3. the maintenance of federal standards to ensure quality vocational education programs, specifying set standards in the areas of teacher credentialing, teacher education, evaluation of vocational education programs, and accountability.

\section{Recommendations at the state Level}

The recommendations at the state level concern pollcy issues, evaluation procedures and dissemination activities.

Policy Issues. The following recommendations are made to the Chancellor's office:

1. review existing procedures on the authorization of funding allocations for programs and services for students with disabilities and evaluate the transfer of funding responsiblities from the Vocational Education Unit to the Specially Funded Programs and Services of the Chancellor's Office.

2. participate in the the reauthorization of the Carl Perkins VEA through a cooperative effort by leaders of vocational education and leaders of DSP\&S. 
3. coordinate services and direct communication lines between the Vocational Education Unit and the Specially Funded Programs and Services.

Evaluation Procedures. The following recommendations are made to the state Chancellor's Office Specially Funded Programs and Services regarding evaluation:

1. prioritize funding for evaluation of vocational education programs for students with disabilities.

2. develop a model evaluation system for evaluating student performance in regular and special vocational programs.

3. provide follow-up evaluation of programs and establish monitoring procedures.

4. conduct need assessments for students with disabilities at the postsecondary level not recelving approprlate services.

Dissemination Aativities. The following recommendations involve dissemination of information from the state level to the district level:

1. disseminate policy information, changes and implications as the reauthorization of the Carl Perkins VEA mounts the legislative platform.

2. inservice district administrators on the distinct uses of VEA and the documentation of services. 
3. research model and innovative vocational education programs within and outside of California community colleges to share and network with DSP\&S staff.

4. inform staff when exemplary monies are avallable in advance of application deadlines.

\section{Recommendations at the Local Level}

This study reported that college specialists and program administrators feel that training and inservices related to VEA can best be arranged at the district level. The majority of staff rported that previous VEA training had been useful. The recommendations at the local level concern training and staff development:

\section{Training/Staff Development}

1. train staff on the Carl Perkins Vocational Education Act, the uses of funds specific to this act, and documentation of these activities.

2. train staff on vocational education components: career assessment, vocational training, job placement, monitoring of services, evaluation, and follow-up.

3. train staff on the vocational needs of persons with disabilities to include students with developmental disabilities, psychiatric disabilities, acquired brain injurles, and substance abuse. 
4. train staff on the recognized models of employment and utllization of these models within the community college system.

\section{Recommendations for Further Study}

Community colleges have responded to the growing demands for services from adult students with disabilities. This study identified many of the vocational services available but it did not examine the quality of these activities. A major recommendation made as a result of this study concerned the evaluation of vocational programs and services. Further study is necessary to determine the long-term effect of these services on students job placement and work performance.

This study examined the training needs of DSP\&S staft regarding VEA funding and indicated that DSP\&S staff felt that districts could provide inservices to best meet their needs. Further study is needed to determine the role university teacher training programs could have on the training of preservice teachers to better prepare them to meet the needs of students at the postsecondary level.

This study reported the allocation of funds and the cost amounts for services provided. It did not however analyze fiscal issues, such as how funds should best be allocated and whether or not monles should be spent on fewer services for more students or more services for fewer 
students. A college surveyed in this study utilized all VEA funds on interpreters for students with hearing disabilities. Another college utilized VEA funds for a separate vocational program for students with varying disabilities, including students with acquired brain injuries, learning disabilities, and developmental disabilities This same college utilized VEA funds for counseling and guidance and basic skill instruction. Further evaluation and study is needed on cost-effectiveness methods for providing services and the importance of providing quality services at any cost.

Finally, this study reported that few separate vocational programs are available through VEA funds. It did not identify why colleges choose not to fund these programs. Further study to determine the reason for this ilmitation and to examine the effect of the excess cost factor on the development of separate programs can assist leaders in decisions made regarding the future of VEA funding. 
REFERENCES

Altschuld, J. W. \& Lower, M. A. (1984). Improving mailed questions: Analysis of a 96 percent return rate. In D. C. Lockhart (Ed.), New Directions for Program Evaluation, 21. 5-18.

Ashcraft, W. W. (1979). The disabled: An untapped labor market. Journal of Contemporary Business, $8(4)$, $75-8 \%$.

Assembly Bill 1725 (1987). Joint Committee for Review of the Master Plan for Higher Education, California Legislature.

Bailey, L. J. \& Stadt, R. W. (1973). Career education: New approaches to human development. Bloomington, IL: McKnight Publishing.

Barlow, M. L. (1967). History of industrial education in the United States. Peorla, IL: Chas. A. Bennett Company.

Batche, C. (1980). Personnel preparation for serving specia) vocational needs populations. In G. Meers (Ed.), Handbook of special vocational needs education (pp. 245-268). Rockville, MD: Aspen Systems Corporation. 
Baumgarten, R. M. \& Heberlein, T. A. (1984). Recent research on mailed questionnalre response rates. In D. C. Lockhart (Ed.), New Directlons for Program Evaluation, 21, 65-75.

Bell, A. R. (1981). Access for the disabled. Community and Junior College Journal, 52(1), 37-38.

Bell amy, G. T., Bertrand, E. F. \& Horner, R. H. (1979). The severely retarded employeed: A new face in the labor market. Journal of Contemporary Business, $8(4)$, 99-106.

Bellamy, G. T., Inman, D., \& Yeates, J. (1978). Evaluation of a procedure for production management with the severely retarded. Mental Retardation, 16(5), 317-319.

Bies, J. D. (1980). The impact of federal legislation on special vocational needs programming. In G. Meers (Ed.), Handbook of special vocational needs education (pp. 29-44). Rockville, MD: Aspen Systems Corporation.

Borbeau, P. (1985). Mobile work crews: An approach to achieve long term supported employment. In P. McCarthy, J. Everson, S. Moon, \& M. Barcus (Eds.), School to work transition for youth with severe disabilities (pp. 151-166). Richmond, VA: Rehabilitation Research and Training Center. 
Borg, W. R. \& Gall, M. D. (1983). Educational research. NY: Longman.

Bottoms, G. \& Copa, P. (1983). A perspective on vocational education today. Phi Delta Kappan, 64(5), 348-354.

Brown, L., Rogan, P., Shlraga, B., Albr lght, K. 2., Kessler, K., Bryson, F., VanDeventer, P., \& Loomis, R. (in press). A vocational foll low up evaluation of the 1984-1986 Madison Metropolitan School Distrlet araduates with severe intellectual disabilities. Madison, WI: University of Wisconsin.

Brustein, M. (1987). Maintenance: What the law says about it. Vecational Education Journal, 62(7), 41.

Bureau of the Census (1984). Statistical abstract of the United States: 1983-84. Washington D.C.: U.S. Government Printing office.

Burton, L. F., Chavez, J. A. \& Kokaska, C. J. (1987). Employabllity skills: A survey of employers' opinions. Journal of Rehabilitation, 53(3), 71-74.

Buzzell, C. H. (1987). The special needs imperative. Vocational Education Journal, $62(7), 10$.

California. Education Code (1977). Title V Requirement, Section 56048 (A) ( 3 ). 
Callfornia. Education Code (1988). Title V Requirement, Chapter 1 of Division 7 of Part VI.

Carl D. Perkins Vocational Education Act (1984). Public Law 98-524. Washington D.C.: U.S. Congress (ERIC Document Reproduction No. 256 926)

Carter, E. H. (1985). Meeting the challenge of change: An opportunity for research in the community college. In $\mathrm{J}$. Losak (Ed.), Applying institutional research in decisionmaking (pp. 85-96). San Francisco, CA: Jossey-Bass.

Celis, W. (1987, January). Generation of retarded youths emerges from public schools - but little awalts. Wall Street Journal, p. 18.

Christian, N. K. \& Steele, L. L. (1982). Education in the 80's: Vocational education. Washington D.C.: National Education Association.

Cohen, A. M. \& Brawer, F. B. (1972). Cenfronting identity: The community college instructior. Engl ewood Cliffs, $\mathrm{NJ}$ : Prentice-Hall.

Cohen, A. M. \& Brawer, F. B. (1977). The two-year colleae instructor today. NY: Praegar. 
Colley, R. (1981). The Education for all Handicapped Children Act (EHA): A statutory and legal analysis. Journal of Law and Education, 10, 137-142.

Combs, I. H. \& Omvig, C. P. (1986). Accommodation of disabled people into employment: Perceptions of employers. Journal of Rehabilitation, 52(2), 42-45.

Conaway, C. (1987). Serving the handicapped: A progress' report. Vocational Education Journal, 62(2), 25-26.

Cross, A. A. (1980). Vecational instruction. Arlington, $V A$ : American Vocational Association.

Crowner, T. T. (1985). A taxonomy of special education finance. Exceptional Children, 51(6), 503-508.

Dahl, P. R., Appleby, J. A., \& Lipe, D. (1978). Mainstreaming ouldeboek for vocational educators. Salt Lake City, UT: Olympus.

Davis, S. R. (1987). Guidelines for vocational special needs. Montpelier, VT: Vermont Department of Education. (ERIC Document Reproduction No. ED 277 857)

Davis, W. E. (1980). Educator's resource quide to special education. Boston, MA: Allyn and Bacon. 
Deegan, W. L. \& Tillery, D. (1987). Toward a 5 th generation of community colleges. Community and Junior College Journal, $53(2), 36-40$.

Documentation oulde for handicapped disadvantaged, and Limited English-proficient students in vocational education programs and services (1986), Sacramento, CA: California State Department of Education (ERIC Document Reproduction No. ED 283332 )

Employing workers with disabillties (1981). Sacramento, CA: Governor's Committee for Employment of the Handi capped.

Expanding educational opportunities for students with disabilities (1986). Sacramento, CA: California Postsecondary Education Commission.

Evans, R. N., Mangum, G. L. \& Pragan, O. (1969). Education for employment; the backaround and potential of the 1968 vocational education amendments. Lansing, Michigan: The Institute of Labor and Industrial Relations.

Feller, R. (1986). A quidebook to a better way: Serving special needs, nen-traditional students and the Perkins Vocational Educational Act. Ft. Collins, CO: Colorado State University. (ERIC Document Reproduction No. ED 284 006) 
Fields, R. R. (1962). The community college movement. NY: McGraw-H111 Book Company.

Fowler, D. (1976). Vocational Education Act in

California. Sacramento, CA: Assembly Public office.

Fox, D. J. (1969), The research process in education. NY: Holt, Rinehart and Winston.

Gold, M. W. (1972). Stimulus factors in skill training of the retarded on a complex assembly task: Acquisition, transfer, and retention. American Journal of Mental Deficiency, 76(5), 517-526.

Gold, M. W. (1974). Redundant cue removal in skill training for the retarded for the mildly and moderately retarded. Education and Tralning of the Mentally Retarded, $q(1)$, 5-8.

Good, C. V. \& Scates, D. E. (1954), Methods of research. NY: Appleton-Century-Crofts.

Greenwood, R. \& Johnson, V. A. (1985). Employer concerns regarding workers with disabilities. Washington, D.C.: National Institution of Handicapped Research. CERIC Document Reproduction Service No. ED 284001 ) 
Greenwood, R. \& Johnson, V. A. (1987). Employer perspectives on workers with disabilities. Journal of Rehabilitation, $53(3), 37-45$.

Guilinger, J. (1987). Expanding special needs. Vocational Education Journal, 62(2), 11 .

Harris, L. (1987). Inside Amerlca. New York, NY: Random House.

Hartman, R. C. $(1981)$. Fact sheet: Community colleges and handicapped students-concerns and resources. Washingt on D.C.: American Council on Education. (ERIC Document Reproduction No. ED 235259 )

Hill, M., Hill, J.W., Wehman, P., Revell, G., Dickerson, A., Noble J. H. (1987). Supported employment: An interagency funding model for persons with severe disabilities. Journal of Rehabllitation, 53 ( 3 ), 13-21.

Hill, M. \& Wehman, P. (1983). Cost benefit analysis of placing moderately and severely handlcapped individuals into competitive employment. Journal of The Association for the Severely Handicapped, 8, 30-38.

H111, M. L., Wehman, P. H., Banks, P. D. \& Metzler, H. M. (in press). Employment outcomes of people with moderate and severe disabllities provided supported compet it ive 
employment after ejaht years. (Grant No. G008301124) Washington D.C.: National Institute on Disabilities and Rehabilitation, U. S. Department of Education.

Hoffmann, F. J., Sheldon, K. L., Minskoff, E. H., Sautter, S. W., Steidle; E. F., Baker, D. P., Balley, M. B. \& Echols, L. D. (1987). Needs of learning disabled adults. Journal of Learning Disabllities, $20(1), 43-51$.

Hol lenbeck, K. M. \& Stevens, D. W. (1987). Vocational education: A shared responsiblity. Vocational Education Journal, 62(2), 25-26.

Howard, R. A. (1981). Perspectives on secondary vocational education for handicapped students. Sacramento, CA: National Association of State Boards of Education.

Howard, R. A. \& Johns, C. C. (1986). Disabled students in the California Community Colleges: A report. Sacramento, CA: Chancellor's Office, Call fornia Community Coll leges.

Jamero, P. M. (1979). Handicapped individuals in the changing workforce. Journal of Centemporary Business, $8(4), 33-42$.

Johns, C. C. (1982). Mobilizing resources for the disabled student in the community colleges state and federal legislation. Proceedings of the Fifth National 
Cenference: Handicapped student service proarams in postsecondacy education: It doesn't cost. it pays! Columbus, $\mathrm{OH}$ : The Association on Handlcapped Student Service Programs in Postsecondary Education.

Jones, W. H. (1979). Generalizing mall survey Inducement methods: Population interactions with anonymity and sponsorhship. Public Oplnion Quarterly, $43(2)$, 102-111.

Kirchner, C., Simon, Z. \& Stern, H. B. (1985). Career planning and visually impaired students: How it's being handled - what needs to be done. Journal of College Placement, 45(4), 53-56.

Lannie, V. P. (1971). The development of vocational education in America: An historical overview. In C. J. Schaefer \& J. J. Kaufman (Eds.) Vocational education: Social and behavioral perspectives. Lexington, MA: D. C. Heath.

Lasden, M. (1982). Untapped talent Computer Decisions, $14(3), 132-138$

Lebed, H. 2. (1985). Employing the disabled is good business: the greatest barriers to people with disabilitles are not their handicaps, but our prejudices. Industry Week 227(1), 14. 
Lester, R. A. \& Caudi11, D. W. (1987). The handicapped worker: Seven myths. Training and Development Journal, $41(8), 50-51$.

Lyons, L. J. (1982). Three insurers take initiative on hiring through Job path program. National Underwriter Property and Casualty, 86(49), 2, 14.

Manks, D. M., Rhodes, L. E., \& Bellamy, G. T. (1986). Four supported employment alternatives. In W. Kiernan \& J. Stark (Eds.), Pathways to employment for developmentally disabled adults. Baltimore: Paul W. Brookes, Inc.

Markowicz, A. (1985). Moving disabled people into the workforce. Washington D.C.: Employment and Training Administration (DOL). (ERIC Document Reproduction Services No. ED 255 688)

McCabe, R. H. (1981). Now is the time to reform the American community college. Community and Junior College Journal, 51(8), 6-10.

McDonnell, J., Wilcox, B. \& S. M. Boles (1986). Do we know enough to plan for transition? Journal of the Association for Persons with Severe Handicaps, $11(1)$, $53-60$. 
McKay, D. A. (1982). Mobilizing resources for disabled students in the community college. Proceedings of the Fifth National Conference: Handicapped student service proarams in postsecondary education: It doesn't cost. it pays! Columbus, $\mathrm{OH}$ : The Association on Handicapped Student Service Programs in Postsecondary Education.

Meers, G. (1980). Handbook of special vocational needs education. Rockville, MD: Aspen Systems Corporation.

Merwick, S. (1980). Identification and utilization support services in serving special vocational needs students. In G. Meers (Ed.) Handboek of special vocational needs education (pp. 205-228). Rockv1lle, MD: Aspen Systems Corporation.

Miller, S. R., Sabatino, D. A. \& Larsen, R. (1980). Issues in the professional preparation of secondary school special educators. Exceptional Children, 45(5), 344-350.

Mithaug, D. E. (1979), Negative employer attitudes toward hiring the handicapped: Fact or fiction?. Journal of Contemporary Business, 8(4), 19-26. 
Moss, J. W., Dineen, J. P., Ford, L. H. (1986). University of Washlngton Employment Training Program. In F. R. Rusch (Ed.), Competitive employment issues and strateqies (pp. 77-85). Baltimore, MD: Paul H. Brookes.

Noble, J. H. \& Conley, R. W. (1987). Accumulating evidence on the benefits and costs of supported and transitional employment for persons with severe disabilities. The Journal of the Association for Persons with Severe Handicaps, $12(3), 163-174$.

O'Nell1, C. \& Bellamy, G. T. (1978). Evaluation of a procedure for teaching saw chain assembly to a severely retarded woman. Mental Retardation, 16(1), 37-40.

Parent, W. S. \& Everson J. M. (1986). Competencies of disabled workers in industry: A review of business literature. Journal of Rehabilitation, 52(1), 16-23.

Pati, G. C. \& Morrison, G. (1982). Enabling the disabled. Harvard Business Review, 60 (4), 152-168.

Patterson, J. B. \& Witten, B. (1987). Myths concerning persons with disabilities. Journal of Applied Rehabilitation Counseling, 18(3), 42-44.

Phillips, K. (1986). Nobody's perfect. Community and Junior college Jeurnal, $23(2), 22-25$. 
Phelps, L. A. (1982). CETA/Vocational education, special education and vocational rehabllitation linkages. Washington D.C.: Office of Special Education and Rehabilitative Services. (ERIC Document Reproduction Service No. ED 224 923)

Plland, W. E. \& Batsche, C. (1985). Support services for special needs students in vocational education. Community College Review, 12(4), 21-26.

Proaram Evaluation Preject (1987). Sacramento, CA: Chancellor's Office, Cal ifornia Community Colleges.

Program for the handicapped (1984). Sacramento, CA: Department of Education, Office of Special Education and Rehabilitation Services.

Report to the leaislature on the Employer Based Training Program (1986), Sacramento, CA: Chancellor's Office, Cal ifornia Community Colleges.

Report to the Legislature on Handicapped student Proarams and Services in the California community colleaes (1981). Sacramento, CA: Chancellor's Office, California Community Coll leges.

Ressler, R. (1973). Career education: The new frontier. Worthington, Ohio: Charles A. Jones. 
Revell, W. G., Wehman, P. \& Arnold, S. (1984). Supported work model of compet it ive employment for persons with mental retardation: Implications for rehabilitative services. Journal of Rehabilitation, 50(4), 33-38.

Rhodes, L. \& Valenta, L. (1985). Industry-based supported employment: An enclave approach. Journal of the Association for Persons with Severe Handicaps, $10(1)$, $12-20$

Roberts, R. W. (1971). Vocational and practical arts education. N.Y.: Harper \& Row.

Rochlin, J. (1987). Transition: An employment perspective. In R. N. Ianacone \& R. A. Stodden (Eds.) Iransitions issues and directions. Reston, VA: The Council for Exceptional Children.

Rusch, F. R. (1986). Competitive employment issues and strategies. Baltimore, MD: Paul H. Brookes.

Rusch, F. R. \& Phelps, L. A. (1987). Secondary special education and transition from school to work: A national priority. Exceptional Children, $53(6), 487-492$.

Sampson, D. (1984). Specialized career services: An AHSSPPE survey. Bulletin of the AHSSPPE, 2 (Winter), 12-20. 
Sathre, R. (1987). A look at the future. Vocational Education Journal, 62(7), 38-40.

Shill, J. F. (1976). Developing vocational education personnel to meet the needs of persons in special groups. In J. E. Wall (Ed.) Vocational education for special groups (pp. 311-320). Washington, D. C.: American Vocational Association.

Shoemaker, B. R. (1987). The case for reauthorization. Vecational Education Journal, 62(7), 34-37.

Sworles, T. R. \& P. H. Wang (1980). Education for handlcapped adults. In E. J. Boone, R. W. Shearon, E. E. White and Assoclates (Eds.), Serving personal and community needs through adult education (pp. 147-166). San Francisco, CA: Jossey-Bass.

Smith, W. P. (1979). A history of vocational education in California 1900-1975. Sacramento, CA: California State Department of Education.

Stodden, R. A. \& Boone, R. (1987). Assessing transitional services for handicapped youth: A cooperative interagency approach. Exceptional Children, 53(6), 537-545.

Sudman, S. \& Bradburn N. (1984). Improving mailed questionnaire design. In D. C. Lockhart (Ed.), New Directions for Program Evaluation, 21, 33-47. 
Terzian, A. \& Thompson S. (1982). Winner: Disabled but determined. Community and Junior College Journal, 533 (3), 39-40.

The Carnegie Foundation for the Advancement of Teaching (1977). Missions of the college curciculum. San Francisco: Jossey-Bass.

Thornton, J. W. (1972). The community junior college. NY: John Wiley \& Sons.

Tindall, L. W. (1982). Vocational education and employment for learning disabled students. St. Louls: MO: American Vocational Association. (ERIC Document Reproduction Services No. ED 226 124)

U.S. Federal Register, 1977, p. 42478.

Vogelsberg, R. T. (1986). Competitive employment in Vermont. In F. R. Rusch (Ed.), Competitive employment issues and strategies, 35-49. Baltimore, MD: Paul H. Brookes.

Wall, J. E. (1976), Vecational education for special groups. Washington D.C.: American Vocational Association .

Walters, N. J. (1986). The factors that led to the passage of the 1963 Vocational Education Act and how the 1968 and 1976 amendments changed this act. Auburn: AL: Center 
for Vocational and Adult Education. Auburn University. (ERIC Document Reproduction Services No. ED 267 299)

Wehman, P. (1986). Competitive employment in Virginia. In F. R. Rusch (Ed.), Competitive employment issues and strategles, 23-33. Baltimore, MD: Paul H. Brookes.

Wehman, P. \& Hill, M. (1983). Cost benefit anaylsis of placing moderately and severely handicapped individuals into competitive employment. Journal of the Association for the Severely Handicapped, $8(1), 30-38$.

Wehman, P., Hill, M., Goodall, P., Cleveland, P., Brooke, V. \& Pentecost, J. H. (1982). Job placement and follow-up of moderately and severely handicapped individuals after three years. Journal of The Asseciation for the Severely Handicapped, I(1), 5-16.

Wehman, P., Hill, J. W. \& Koehler, F. (1979). Helping severely handicapped persons enter competitive employment. AAESPH ReView, 4(3), 274-290.

Wehman, P. \& Kregel, J. (1983). The supported work model: Toward job placement and retention of severely handicapped individuals. Journal of The Association for the Severely Handicapped, $10(1), 3-9$. 
Wehman, P., Kregel, J. \& Barcus, J. M. (1985). From school to work: A model for handicapped students, Exceptional Chlldren, 52(1), 25-37.

Wehman, P. \& Mella, R. (1985). The job coach: Function in transitional and supported employment. American Rehabilitation, 11(2), 4-7.

Wehman, P. \& Pentecost, J. H. (1982). Facilitating employment for moderately and severely handicapped youth. Richmond, VA: Virginia Commonwealth University.

Weicker, I. P. (1987), A look at policy and its effect on special education and vocational rehabilitation services. Career Development for Exceptional Individuals, 10(1), 6-9.

Will, M. (1984). Bridges from school to working life. Programs for the handlaapped, 2, 1-5.

Wisconsin State Department of Public Instruction (1985). Qverview and proposal development quidelines, Carl D, Perkins Vocational Education Act. Madison, WI : Bureau for Vocational Education. (ERIC Document Reporduction Service No., ED 254 739) 
Worthington, R. M. (1985), Vecational and adult education: major requlation issues. Washington D.C.: Office of Vocational and Adult Education. (ERIC Document Reproduction Services No. ED 260 251)

Wright, C. E., Kim Y. \& Wing, L. C. (1985). Directory of California Community Colleges exemplary programs and materials for handlcapped populatlon students. Menlo Park, CA: Educational Evaluation and Research, Inc.

Wysocki, J. \& Wysocki, P. (1979). An employer's guide to employment and disability. Journal of Contemporary Business, 오(4), 59-66.. 


\section{APPENDIX A}

Questionnaire

144

Reproduced with permission of the copyright owner. Further reproduction prohibited without permission. 
COLLEGE:

Name of person completing survey:

Position:

1. VEA SERVICES \& ACTIVITIES

Following is a list of "acceptable activities and services" wich meet the requirements of VEA funding.

A. Please check all of the services your college provides to students in each of the categories listed.

\begin{tabular}{|c|c|c|c|c|c|c|c|c|}
\hline $\begin{array}{l}\text { DISABILITY } \\
\text { CATEGORY }\end{array}$ & $\begin{array}{l}\text { BASIC } \\
\text { SKILIS } \\
\text { INSTRUC- } \\
\text { TION }\end{array}$ & $\begin{array}{l}\text { COOPERA- } \\
\text { TIVE VOC } \\
\text { ED PROG. }\end{array}$ & $\begin{array}{l}\text { CAREIR } \\
\text { GUID- } \\
\text { ANCE \& } \\
\text { COUN- } \\
\text { SELING }\end{array}$ & $\begin{array}{l}\text { PEER } \\
\text { COUN- } \\
\text { SELING }\end{array}$ & $\begin{array}{l}\text { PLACEMENT } \\
\text { SERVICES } \\
\text { EOR COM- } \\
\text { PLETERS }\end{array}$ & $\begin{array}{l}\text { MOBILITY } \\
\text { ASSISTANCE }\end{array}$ & $\left|\begin{array}{l}\text { SPECIAL } \\
\text { VOCATION- } \\
\text { AL } \\
\text { PROGRAMS }\end{array}\right|$ & $\begin{array}{l}\text { REMEDIAL } \\
\text { COURSES }\end{array}$ \\
\hline $\begin{array}{l}\text { PHYSICAL } \\
\text { DISABILITY }\end{array}$ & \multicolumn{8}{|c|}{ 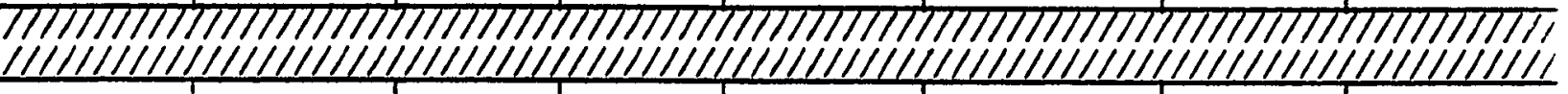 } \\
\hline $\begin{array}{l}\text { Vision } \\
\text { Impaired }\end{array}$ & & & & & & & & \\
\hline $\begin{array}{l}\text { Mobility } \\
\text { Impaired }\end{array}$ & & & & & & & & \\
\hline $\begin{array}{l}\text { Other } \\
\text { Health }\end{array}$ & & & & & & & & \\
\hline $\begin{array}{l}\text { COMUNI- } \\
\text { CATION } \\
\text { DISABILITY }\end{array}$ & \multicolumn{8}{|c|}{ 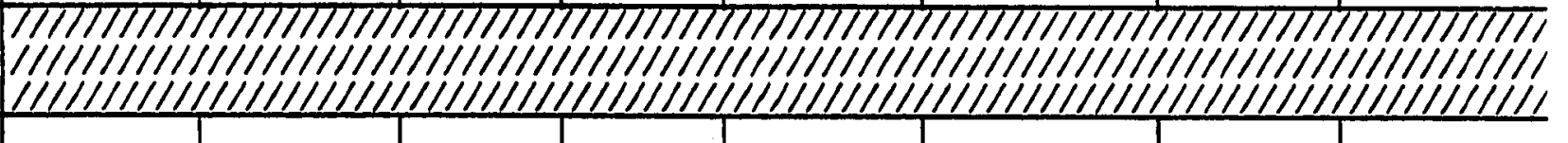 } \\
\hline $\begin{array}{l}\text { Speech } \\
\text { Impaired }\end{array}$ & & & & & & & & \\
\hline $\begin{array}{l}\text { Hearing } \\
\text { Impaired }\end{array}$ & & & & & & & & \\
\hline$\pi 11111111$ & 71111111 & 71 & $\pi 17$ & $\underline{Z}$ & 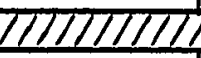 & 771 & 111111111 & पाIIIIIII \\
\hline $\begin{array}{l}\text { LEARNING } \\
\text { DISABLED }\end{array}$ & & & & & & & & \\
\hline 7777171717 & 771171717 & 777171717 & 71717 & 71771 & 7717171 & 711171111 & 717171717 & 7117111111 \\
\hline $\begin{array}{l}\text { DEVELOP- } \\
\text { IENTALLY } \\
\text { DELAYED } \\
\text { LEARNER }\end{array}$ & & & & & & & & \\
\hline 1111117111 & 7111111111 & 77111 & Z111117 & 1117111 & T11117117 & ग1111111111 & 171111111 & 17111111 \\
\hline $\begin{array}{l}\text { ACQUIRDD } \\
\text { BRAIN } \\
\text { INJURY } \\
\end{array}$ & & & & & & & & \\
\hline 11111111171 & 111111 & 717 & T171 & 11171 & 711111111 & पIIIII & 11111111 & 71111111 \\
\hline $\begin{array}{l}\text { PSYCHIATRIC } \\
\text { DISABILITY }\end{array}$ & & & & & & & & \\
\hline 1111111111 & 711 & 2111111711 & IIIIIII & 711717 & 1711117171 & 111111111 & 171 & $\pi$ \\
\hline $\begin{array}{l}\text { SUBSTANCE } \\
\text { ABUSE. }\end{array}$ & & & & & & & & \\
\hline
\end{tabular}


B. Please check if your college uses VEA funds to provide any of the following:

Interpreters (Hearing Impaired) Readers (Visually Impaired) Tutoring (LD)
[ ] Recruitment

[ ] Administration

[ ] Program Coordination or Supervision [ ]

C. Please indicate the number of disabled students served with VEA funds in each disability group. If exact numbers are not available, please estimate.

Visually Impaired

Mobility Impaired

Other Health Impai ment

Speech Impairment

Deaf or Hard of Hearing
Learning Disabled

Developmentally Delayed Learner

Acquired Brain Injury

Psychiatric Disability

Substance Abuse

D. If your college utilizes VEA funds for special vocational programs, please indicate the service delivery model(s) utilized:

Work/mobile crew (A contracted business with a crew of individuals with disabilities performing service jobs. The employer pays an agency for the service.)

Enclave (A group of individuals with disabilities working as a unit within a business. The employer pays wages to each worker.)

Supported Employment (Provides ongoing support to an individual with a disability in employment. The employer provides wages directly to the worker.)

Unsubsidized work experience (Provides ongoing support to an individual with a disability in training. No wages are received by the worker.)

Shel tered workshop (Provides ongoing support in a segregated facility for disabled employees only. Wages are received according to levels of production.) 


\section{UTILIZATION OE VEA EXPENDITURES}

Please refer to your 1987-88 VEA Budget. The following question relates to the major expenditures of your budget (costs ovar $50 \%$ of the total). List the three highest costs in your budget and briefly describe how they are being used.*

Example: Component

(1) Teachers salaries

COMPONENT

(1)

(2)

(3)

(2)

3)

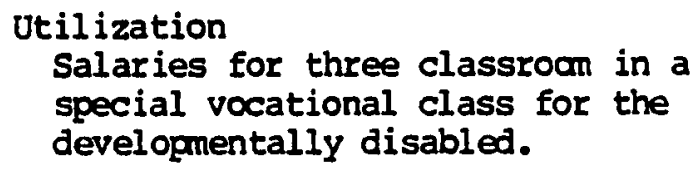

UTILIZATION

* Please use the back of form if more space is needed.

3. TRAINING FOR VEA FUNDS UTILIZATION

(A) Mark the box to the left of the topics listed below if you have received training in them. Indicate your need for training in the box to the right.

\begin{tabular}{|c|c|c|c|c|c|c|}
\hline $\begin{array}{l}\text { RECEIVED } \\
\text { TRAINING }\end{array}$ & & $\begin{array}{l}\text { DEEIN } \\
\text { DO NO }\end{array}$ & $\begin{array}{l}\text { ITELY } \\
\text { T NEED }\end{array}$ & MAY NEED & $\begin{array}{l}\text { LIKELY } \\
\text { TO NEED }\end{array}$ & $\begin{array}{c}\text { DEFIN- } \\
\text { ITELYY } \\
\text { NEED }\end{array}$ \\
\hline [ ] & How to apply for funding & & [ ] & [ ] & [ ] & [ ] \\
\hline [ ] & VEA documentation & & [ ] & [ ] & [ ] & [ ] \\
\hline$[$ ] & Appropriate uses of VEA & funds & {[]} & {[]} & {$[1]$} & [ ] \\
\hline [ ] & $\begin{array}{l}\text { Carl Perkins Vocational } \\
\text { Educational Act }\end{array}$ & & {[]} & {$[1]$} & 11 & [ ] \\
\hline [ ] & Other: & & [ ] & [ ] & {$[1$} & [ ] \\
\hline
\end{tabular}


(B) Please rate any training you received in the following areas:

$\begin{array}{cll}\text { OF NO } & \text { SOME- } & \\ \text { USE } & \text { WHAT } & \text { VERY } \\ \text { AT ALL } & \text { USEFUL USEEUL USEFUL }\end{array}$

$\begin{array}{lllll}\text { How to apply for funding } & 1 & 2 & 3 & 4 \\ \text { VEA documentation } & 1 & 2 & 3 & 4 \\ \text { Appropriate uses of VEA funds } & 1 & 2 & 3 & 4 \\ \begin{array}{l}\text { Carl Perkins Vocational } \\ \text { Educational Act }\end{array} & 1 & 2 & 3 & 4 \\ \text { Other: } & 1 & 2 & 3 & 4\end{array}$

(C) If you would like training, check the delivery method(s) you feel would best assist you:

District inservice

Association - Sponsored conferences

Li terature

Personal contact with other college

specialist using VEA funds.

[]
$\left[\begin{array}{l}] \\ {[}\end{array}\right]$
[]

4. VEA EXEMPLARY PROGRAMS \& PROJECTS

VEA funds exemplary prograns and materials, please check if your college has applied for and received funding for any of the following:

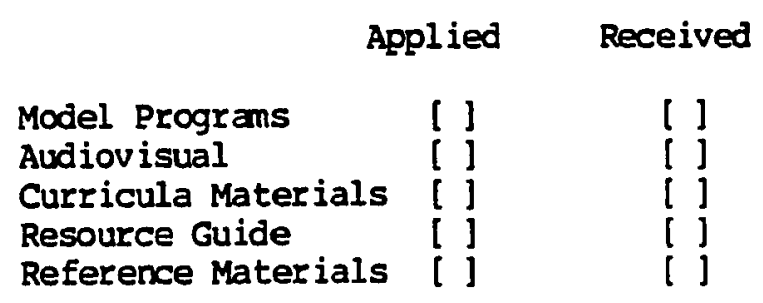


USE THIS FORM TO IDENTIEY EXEMPLARY AND/OR MODET VEA PROGRAMS EOR DISABLED STUDENTS

LENGIH OE PROGRAM (NUMBER OF YEARS EUNDED) :

TOTAL NUMBER OF STUDENTS SERVED:

TITLE:

BRIEF DESCRIPTION: (Attach any literature/infomation on program)

CBJECTIVES OF PROGRAM(S) :

OUTCOMES:

VOCATIONAL SERVICES

Please rate the time and emphasis your program places on any of the services listed below with (1) being the highest priority, (9) the least.

Vocational Counseling

Vocational Assess

Career Exploration

Vocational Training/work Experience

Job Placement

Job Monitoring

Job Retention

Follow-up Services

Other

PRODUCTS \& PROGRAM COMPONENIS

Please check any of the components included in your exemplary or model program.

$\begin{array}{ll}\text { Budgeting/Banking } & {[\text { ] }} \\ \text { Mobility } & {[\text { ] }} \\ \text { Socialization } & {[\text { ] }} \\ \text { Home Management } & {[\text { ] }} \\ \text { Peer Support } & {[\text { ] }} \\ \text { Recreation \& Leisure } & {[\text { ] }} \\ \text { Basic/Functional Acadenics } & {[\text { ] }}\end{array}$


Please check any products which your exemplaxy or model program has developed.

Information Sheet/Brochure
Literature
Audiovisual Materials
Curricula Materials
Published Evaluation Reports
Other

$\left.\begin{array}{l}1 \\ {[} \\ 1 \\ 1 \\ 1 \\ 1\end{array}\right]$

Would you be willing to share ongoing information on your program with other college specialists?

If yes, please complete the following:

Name:

Telephone:

Address:

Caments: 
APPENDIX B

Cover Letter for Questionnaire

151

Reproduced with permission of the copyright owner. Further reproduction prohibited without permission. 
CALIFORNIA COMMUNITY COLLEGES

1107 NINTH STREET

SACRAMENTO, CALIFORNIA 95814

(916) 445-8752

February 5, 1987

TO:

FROM: Ronn Farland

Acting Vice Chancellor

Academic Affairs

Ron Dyste

Vice Chancellor

Student Services \& Special Programs

SUBJECT: Utilization of VEA Funds For students with Disabilities.

Since the enactment of the Vocational Education Act seventy years ago, federal aid has made a significant impact on the vocational education of students in public schools. Within the last two decades, amendments allowing for set aside monies for persons with special needs, including students with disabilities, have ensured equal access to vocational education.

To maximize the effect of VEA funding on the services provided to students with disabilities in the community colleges, there exists a need to gather information on available programs and services. Therefore, we are conducting a survey to determine the distribution and utilization of VEA funding for students with varying disabilities attending California community colleges.

The first four pages of this survey request information on the services available to students, the utilization of funding, and training. Completion of this section should take no more than 1520 minutes.

If you can identify an innovative model program at your college which is funded through VEA and/or receives funding for VEA exemplary programs and materials, please complete the attachments. This is voluntary information but will provide critical data on activities available within the colleges. The information you provide regarding innovative and exemplary programs will be used as a resource for VEA programs and made available to other college specialists. 
Your cooperation will be greatly appreciated. The survey results will be distributed for your information. If you have any questions, please feel free to call susan Sargent (619)584-6983 who is assisting us with this project.

Please return the survey no later than March 11, 1988 to:

Susan Sargent

San Diego Community College District

3375 Camino del Rio South

San Diego, California 92108

Thank you for your assistance with this project. 


\section{APPENDIX C \\ Follow-Up Cover Letter}

154

Reproduced with permission of the copyright owner. Further reproduction prohibited without permission. 
To:

DSP\&S Program Administrators

FROM: Robert F. Howard

Acting Dean, Special Services Unit

Student Services and Special Programs Division

SUBJECT: Utilization of VEA Funds For students with

Disabilities.

Recently you received a survey regarding the utilization of VEA funds at your college. This research will provide needed information to maximize the effects of VEA funding for students with disabilities attending California commuity colleges.

The survey was designed to be answered easily and should only take approximately 15-20 minutes to complete. We have enclosed a second questionnaire for your convenience and would like to request that you complete it as soon as possible.

We appreciate your contribution to this study and thank you for your time and support.

If you have already completed a copy of the questionnaire, please disregard this letter. And thank you once again!

PLEASE RETURN BY MAY 29

To: Susan Sargent

San Diego Community College District

3375 Camino del Rio South

San Diego, CA 92108

RFH : SS : wV

cc: Emmett Casey

Susan Cota

Catherine Johns 


\section{APPENDIX D}

Statistical Computations

156

Reproduced with permission of the copyright owner. Further reproduction prohibited without permission. 
SUMMARY STATISTICS: DISABILITIES

FSYCH

SUBIMPAIRED IMPAIRED IMPAIRED DISABLED DELAVED INJURV DISORDER STANCE

\begin{tabular}{|c|c|}
\hline 1 & 5 \\
\hline 2 & 0 \\
\hline 3 & 4 \\
\hline 4 & 15 \\
\hline 5 & 14 \\
\hline 7 & 0 \\
\hline 8 & 6 \\
\hline 9 & 0 \\
\hline 10 & 1 \\
\hline$i 1$ & 4 \\
\hline 12 & 8 \\
\hline 13 & 1 \\
\hline 14 & 2 \\
\hline 15 & 0 \\
\hline 16 & 4 \\
\hline 17 & 5 \\
\hline 18 & 29 \\
\hline 19 & 2 \\
\hline 21 & 2 \\
\hline 22 & 0 \\
\hline 24 & 6 \\
\hline 25 & 12 \\
\hline 26 & 5 \\
\hline 29 & 6 \\
\hline 30 & 7 \\
\hline 31 & 7 \\
\hline 32 & 0 \\
\hline 34 & 0 \\
\hline 36 & 0 \\
\hline 37 & 3 \\
\hline 41 & 1 \\
\hline 42 & 3 \\
\hline 44 & 5 \\
\hline 45 & 4 \\
\hline 46 & 4 \\
\hline 48 & 7 \\
\hline 51 & 15 \\
\hline 52 & 5 \\
\hline 53 & 2 \\
\hline 54 & 1 \\
\hline 55 & 5 \\
\hline 56 & 2 \\
\hline 57 & 2 \\
\hline 58 & 30 \\
\hline 59 & 10 \\
\hline 60 & 0 \\
\hline 61 & 6 \\
\hline 64 & 3 \\
\hline 69 & 5 \\
\hline 70 & 0 \\
\hline 72 & 2 \\
\hline 73 & 3 \\
\hline
\end{tabular}

43
6
50
5
15
0
25
23
10
10
15
8
3
5
13
7
70
10
6
0
6
69
3
8
23
17
0
25
0
7
0
15
38
17
5
0
33
65
10
0
23
33
0
10
30
5
11
0
14
0
1
0

$\begin{array}{rr}8 & 15 \\ 0 & 3 \\ 2 & 6 \\ 15 & 12 \\ 1 & 4 \\ 0 & 0 \\ 7 & 4 \\ 0 & 1 \\ 2 & 1 \\ 0 & 4 \\ 1 & 5 \\ 0 & 18 \\ 0 & 5 \\ 0 & 4 \\ 1 & 3 \\ 18 & 33 \\ 2 & 14 \\ 0 & 4 \\ 1 & 5 \\ 0 & 0 \\ 2 & 5 \\ 13 & 40 \\ 0 & 0 \\ 2 & 2 \\ 9 & 20 \\ 0 & 5 \\ 0 & 0 \\ 0 & 5 \\ 0 & 0 \\ 0 & 15 \\ 0 & 5 \\ 4 & 4 \\ 1 & 4 \\ 16 & 9 \\ 0 & 1 \\ 3 & 21 \\ 0 & 47 \\ 15 & 13 \\ 0 & 0 \\ 0 & 1 \\ 0 & 0 \\ 1 & 1 \\ 0 & 2 \\ 20 & 10 \\ 0 & 33 \\ 0 & 2 \\ 0 & 4 \\ 0 & 5 \\ 0 & 2 \\ 0 & 0 \\ 2 & 3 \\ 9 & 1\end{array}$

$\begin{array}{rr}24 & 0 \\ 15 & 0 \\ 40 & 40 \\ 50 & 60 \\ 250 & 0 \\ 7 & 12 \\ 50 & 0 \\ 37 & 0 \\ 20 & 2 \\ 5 & 25 \\ 114 & 0 \\ 12 & 0 \\ 15 & 1 \\ 25 & 5 \\ 37 & 1 \\ 52 & 3 \\ 159 & 18 \\ 66 & 180 \\ 22 & 0 \\ 50 & 0 \\ 34 & 8 \\ 127 & 0 \\ 40 & 0 \\ 48 & 0 \\ 54 & 0 \\ 45 & 0 \\ 52 & 8 \\ 70 & 5 \\ 0 & 0 \\ 55 & 0 \\ 50 & 0 \\ 20 & 5 \\ 22 & 43 \\ 150 & 0 \\ 103 & 10 \\ 82 & 1 \\ 0 & 0 \\ 60 & 6 \\ 50 & 3 \\ 14 & 0 \\ 5 & 0 \\ 42 & 1 \\ 22 & 0 \\ 100 & 30 \\ 40 & 4 \\ 15 & 10 \\ 30 & 4 \\ 10 & 0 \\ 0 & 0 \\ 0 & 3 \\ 28 & 0 \\ 31 & \end{array}$

1
0
20
5
7
50
20
0
0
10
6
3
0
4
1
10
12
0
3
0
20
8
1
2
9
4
0
0
0
0
5
8
4
10
0
26
0
2
0
1
0
12
9
2
2
3
14
0
2
0
1
10


SUMMARY STATISTICS: DISABILITIES

VISUALLV MOBILITY HEALTH SPEECH HEARING LEARNING IMPAIRED IMPAIRED IMPAIRED IMPAIRED DISABLED

DEVEL.
DELAYED

BRAIN
INJURY DSYCH.

SUBSTANCE

\begin{tabular}{|c|c|c|c|c|c|c|c|c|c|c|c|}
\hline & 74 & 0 & 0 & 0 & 0 & 0 & 19 & 1 & 0 & 0 & D \\
\hline & 75 & 5 & 30 & 5 & 0 & 10 & 25 & 0 & 5 & 0 & 0 \\
\hline & 77 & 20 & 120 & 100 & 10 & 250 & 10 & 0 & 0 & 0 & 0 \\
\hline & 78 & 0 & 0 & 11 & 0 & 0 & 0 & 0 & 0 & 0 & 0 \\
\hline & 79 & 7 & 44 & 16 & 0 & 5 & 29 & 24 & 3 & 4 & 0 \\
\hline & 81 & 0 & 2 & 0 & 0 & 1 & 39 & 0 & 0 & 0 & 0 \\
\hline & 83 & 4 & B & 10 & 1 & 1 & 10 & 0 & 1 & 0 & 0 \\
\hline & 84 & 5 & 29 & 37 & 1 & 0 & 40 & 10 & 2 & 0 & 0 \\
\hline & $\begin{array}{l}84 \\
88\end{array}$ & 0 & 10 & 30 & 1 & 2 & 17 & 0 & o & 0 & 0 \\
\hline & 91 & 0 & 0 & 0 & 0 & $\overrightarrow{0}$ & 0 & 0 & 0 & 0 & 0 \\
\hline & 92 & 8 & 12 & 4 & 0 & 2 & 51 & 0 & 6 & 0 & 0 \\
\hline & 93 & 8 & 40 & 27 & 3 & 4 & 10 & D & 3 & 0 & 0 \\
\hline & 94 & 0 & 0 & 0 & 0 & 0 & 80 & 0 & 0 & 0 & 0 \\
\hline & $\begin{array}{l}34 \\
95\end{array}$ & 2 & 5 & 5 & 2 & 2 & 6 & 4 & 2 & 0 & 2 \\
\hline & 96 & 0 & 0 & 0 & 0 & 0 & 30 & 0 & 0 & 0 & 0 \\
\hline & 97 & 14 & 50 & 70 & 3 & 5 & 35 & 0 & 20 & 20 & 0 \\
\hline & 101 & 8 & 206 & 142 & 0 & 228 & 47 & 0 & 0 & 20 & 0 \\
\hline & 102 & 0 & 6 & $\begin{array}{r}142 \\
0\end{array}$ & 0 & 20 & 0 & 0 & 0 & 0 & 0 \\
\hline & $\begin{array}{l}102 \\
103\end{array}$ & 5 & 0 & 0 & 20 & 0 & 0 & 0 & 0 & 0 & 0 \\
\hline & 104 & 0 & 3 & 2 & 0 & 38 & 13 & 18 & 7 & 0 & 0 \\
\hline N & 72 & 72 & 72 & 72 & 72 & 72 & 72 & 72 & 72 & 72 & 71 \\
\hline Mean & 49 & 5 & 34 & 17 & 3 & 13 & 40 & 8 & 5 & 3 & 2 \\
\hline Minimum & 1 & 0 & 0 & 0 & 0 & 0 & 0 & 0 & 0 & 0 & 0 \\
\hline Maximum & 104 & 30 & 206 & 142 & 20 & 250 & 250 & 180 & 50 & 23 & 20 \\
\hline Sum & 3548 & 349 & 2418 & 1251 & 196 & 969 & 2910 & 545 & 356 & 188 & 114 \\
\hline
\end{tabular}


SUMMARY STATISTICS: REPORT I

\begin{tabular}{rr}
1 & \\
2 & $\$ 27.717$ \\
3 & $\$ 9.820$ \\
4 & $\$ 75.759$ \\
5 & $\$ 51.286$ \\
6 & $\$ 30.897$ \\
7 & $\$ 45.228$ \\
8 & $\$ 45.741$ \\
9 & $\$ 27.630$ \\
10 & $\$ 27.992$ \\
11 & $\$ 10.294$ \\
12 & $\$ 36.480$ \\
13 & $\$ 44.061$ \\
14 & $\$ 31.632$ \\
15 & $\$ 33.685$ \\
16 & $\$ 10.148$ \\
17 & $\$ 19.811$ \\
18 & $\$ 69.899$ \\
19 & $\$ 136.652$ \\
20 & $\$ 38.765$ \\
23 & $\$ 14.275$ \\
24 & $\$ 41.873$ \\
26 & $\$ 27.261$ \\
27 & $\$ 24.758$ \\
28 & $\$ 35.172$ \\
29 & $\$ 33.773$ \\
31 & $\$ 29.112$ \\
33 & $\$ 12.792$ \\
34 & $\$ 6.329$ \\
35 & $\$ 46,081$ \\
36 & $\$ 12.267$ \\
37 & $\$ 47.673$ \\
39 & $\$ 63.054$ \\
40 & $\$ 26.248$ \\
41 & $\$ 103.471$ \\
42 & $\$ 17.368$ \\
43 & $\$ 39.818$ \\
44 & $\$ 11.722$ \\
46 & $\$ 93.086$ \\
47 & $\$ 11.219$ \\
48 & $\$ 19.291$ \\
49 & $\$ 45.944$ \\
50 & $\$ 66.828$ \\
51 & $\$ 40.039$ \\
108 & $\$ 67.093$ \\
109 & $\$ 11.939$ \\
110 & $\$ 201.611$ \\
111 & $\$ 220.196$ \\
112 & $\$ 60.377$ \\
113 & $\$ 35.256$ \\
114 & $\$ 180.492$ \\
115 & $\$ 106.560$ \\
& \\
\hline 15
\end{tabular}

$\begin{array}{rr}21.55 \% & 19.40 \% \\ 17.21 \% & 14.65 \% \\ 29.78 \% & 36.81 \% \\ 23.45 \% & 12.32 \% \\ 12.33 \% & 6.04 \% \\ 36.62 \% & 15.12 \% \\ 38.47 \% & 20.74 \% \\ 11.70 \% & 16.85 \% \\ 22.79 \% & 14.98 \% \\ 15.84 \% & 13.37 \% \\ 17.55 \% & 29.85 \% \\ 29.63 \% & 12.84 \% \\ 13.90 \% & 23.30 \% \\ 23.76 \% & 20.96 \% \\ 19.46 \% & 7.00 \% \\ 10.15 \% & 9.30 \% \\ 18.14 \% & 26.12 \% \\ 18.72 \% & 56.12 \% \\ 34.70 \% & 19.15 \% \\ 15.56 \% & 10.96 \% \\ 37.64 \% & 33.17 \% \\ 21.26 \% & 15.20 \% \\ 22.34 \% & 22.35 \% \\ 8.58 \% & 9.06 \% \\ 18.15 \% & 16.73 \% \\ 18.30 \% & 13.85 \% \\ 13.60 \% & 11.84 \% \\ 17.14 \% & 5.86 \% \\ 15.75 \% & 30.41 \% \\ 11.64 \% & 13.01 \% \\ 15.83 \% & 22.45 \% \\ 15.29 \% & 18.10 \% \\ 29.77 \% & 21.36 \% \\ 18.62 \% & 45.13 \% \\ 23.04 \% & 4.93 \% \\ 19.46 \% & 22.70 \% \\ 13.30 \% & 25.85 \% \\ 20.75 \% & 44.28 \% \\ 27.25 \% & 12.42 \% \\ 10.54 \% & 14.70 \% \\ 14.70 \% & 20.00 \% \\ 23.50 \% & 30.36 \% \\ 13.37 \% & 18.31 \% \\ 16.46 \% & 23.42 \% \\ 21.89 \% & 17.78 \% \\ 21.54 \% & 31.69 \% \\ 16.84 \% & 15.22 \% \\ 9.10 \% & 14.07 \% \\ 19.48 \% & 14.89 \% \\ 12.90 \% & 1 . .24 \% \\ 30.13 \% & 42.30 \% \\ 14.31 \% & 24.62 \% \\ & \end{array}$


SUMMARY STATISTICS: REPORT I

IDI VEA $\$$
HANDICAPPED

TOTAL. VEA
BUDGET

$\$ 303.673$ $\$ 333.306$
$\$ 412.856$ $\$ 160.351$ $\$ 288.020$

Mean

Miniunum Maximum Sum

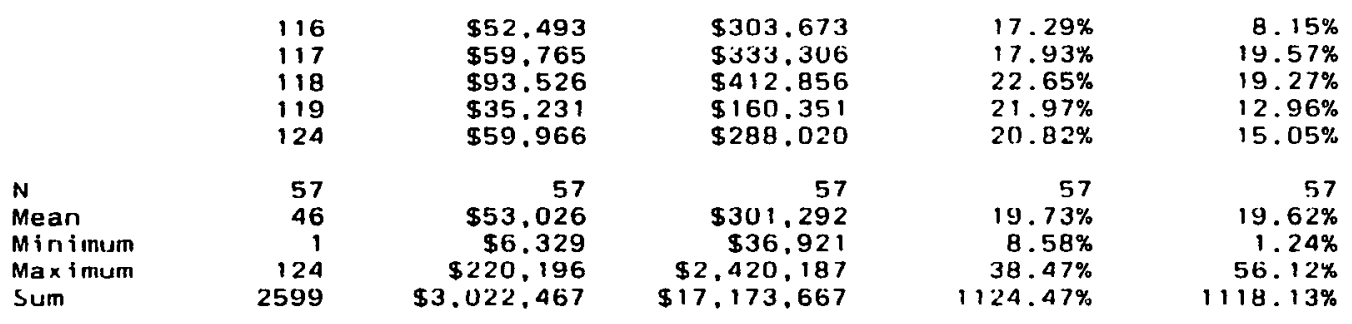

PERCENT OF PERCENT OF

TOTAL VEA

ISPS 
DIRECT COSTS

IDI TEACH- SUPER- COUNS- CLER- IN-

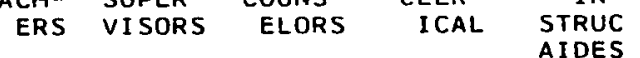

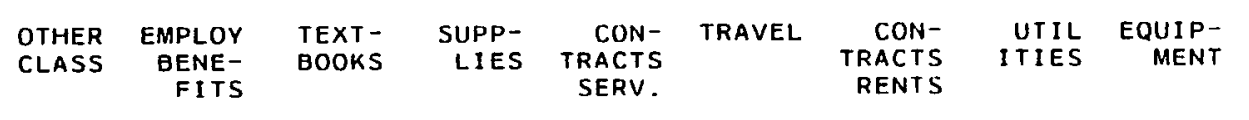

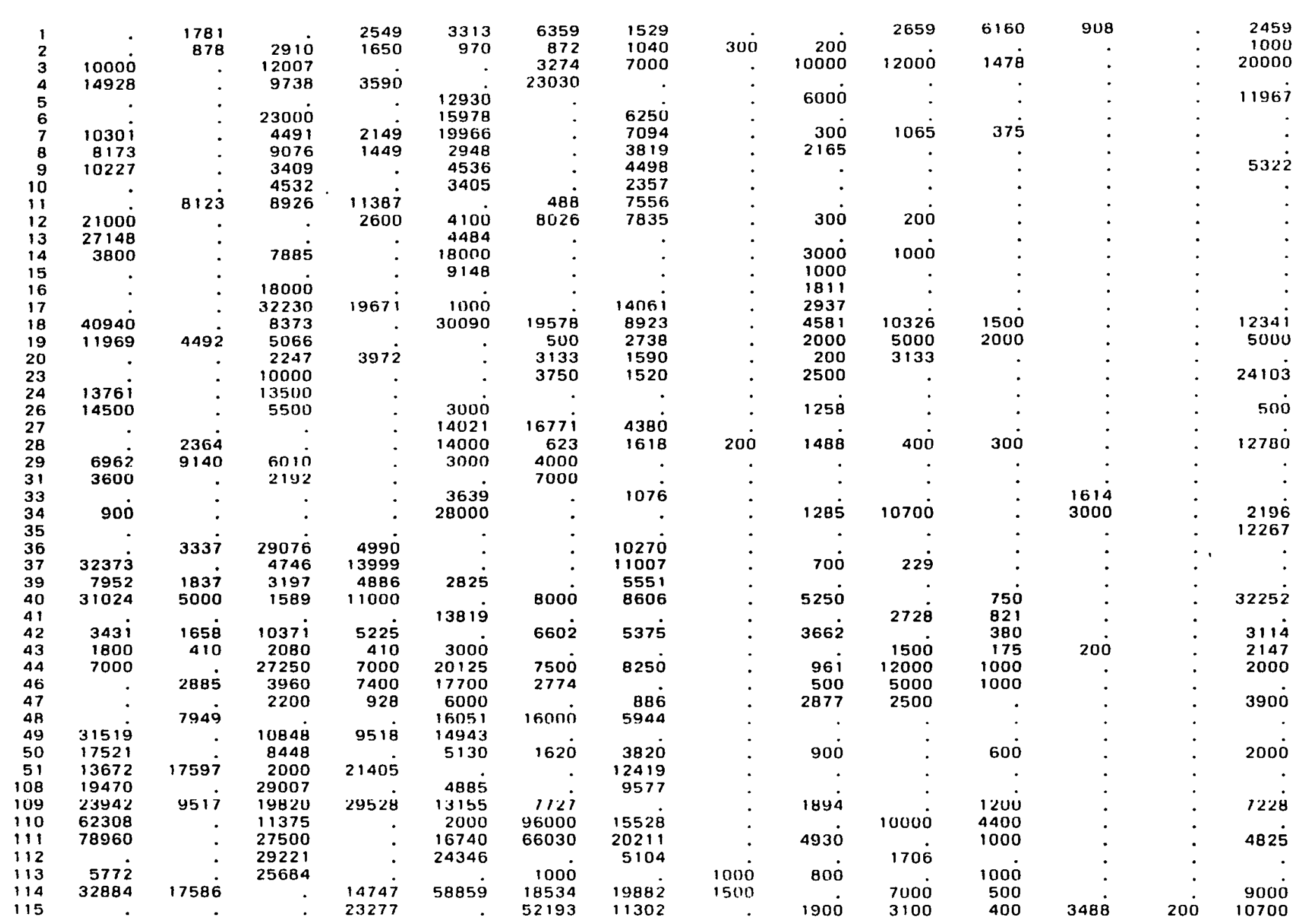


DIRECT COSTS

\begin{tabular}{|c|c|c|c|c|c|c|c|c|c|c|c|c|c|c|c|}
\hline A & IDI & $\begin{array}{r}\text { TEACH- } \\
\text { ERS }\end{array}$ & $\begin{array}{l}\text { SUPER- } \\
\text { VI SORS }\end{array}$ & $\begin{array}{c}\text { COUNS- } \\
\text { ELORS }\end{array}$ & $\begin{array}{l}\text { CLER- } \\
\text { ICAL }\end{array}$ & $\begin{array}{r}\text { IN- } \\
\text { STRUC } \\
\text { AIDES }\end{array}$ & $\begin{array}{l}\text { OTHER } \\
\text { CLASS }\end{array}$ & $\begin{array}{r}\text { EMPLOY } \\
\text { BENE- } \\
\text { FITS }\end{array}$ & $\begin{array}{l}\text { TEXT- } \\
\text { BOOKS }\end{array}$ & $\begin{array}{l}\text { SUPP- } \\
\text { LIES }\end{array}$ & $\begin{array}{l}\text { CON- } \\
\text { TRACTS } \\
\text { SERV. }\end{array}$ & TRAVEL & $\begin{array}{r}\text { CON- } \\
\text { TRACTS } \\
\text { RENTS }\end{array}$ & $\begin{array}{l}\text { UTIL } \\
\text { ITIES }\end{array}$ & $\begin{array}{l}\text { EQUIP- } \\
\text { MENT }\end{array}$ \\
\hline & $\begin{array}{l}116 \\
117 \\
118 \\
119 \\
124\end{array}$ & $\begin{array}{r}4633 \\
:\end{array}$ & 11777 & $\begin{array}{r}2811 \\
3258 \\
40577 \\
11431 \\
15451\end{array}$ & $\begin{array}{r}14872 \\
5673 \\
6334 \\
5178\end{array}$ & $\begin{array}{r}4397 \\
33196 \\
28581 \\
10757 \\
.\end{array}$ & $\begin{array}{r}17241 \\
10033 \\
7272 \\
4000\end{array}$ & $\begin{array}{r}6339 \\
684 \\
2494 \\
2601 \\
10481\end{array}$ & : & $\begin{array}{r}2200 \\
11798 \\
2229 \\
1405\end{array}$ & $150 \dot{0}$ & $\begin{array}{r}796 \\
2200 \\
500\end{array}$ & : & $\dot{.}$ & $\begin{array}{l}3000 \\
4108 \\
2484\end{array}$ \\
\hline $\begin{array}{l}\text { N } \\
\text { Mean } \\
\text { Min imum } \\
\text { Max imum } \\
\text { Suin }\end{array}$ & $\begin{array}{r}57 \\
46 \\
1 \\
124 \\
2599\end{array}$ & $\begin{array}{r}32 \\
18161 \\
900 \\
78960 \\
581160\end{array}$ & $\begin{array}{r}17 \\
6255 \\
410 \\
17597 \\
106331\end{array}$ & $\begin{array}{r}43 \\
11884 \\
1589 \\
40577 \\
510992\end{array}$ & $\begin{array}{r}27 \\
8718 \\
410 \\
29528 \\
235387\end{array}$ & $\begin{array}{r}39 \\
12642 \\
970 \\
58859 \\
493037\end{array}$ & $\begin{array}{r}30 \\
13998 \\
488 \\
96000 \\
419930\end{array}$ & $\begin{array}{r}39 \\
6098 \\
684 \\
20211 \\
261215\end{array}$ & $\begin{array}{r}4 \\
750 \\
200 \\
1500 \\
3000\end{array}$ & $\begin{array}{r}32 \\
2595 \\
200 \\
11798 \\
83031\end{array}$ & $\begin{array}{r}21 \\
4464 \\
200 \\
12000 \\
93746\end{array}$ & $\begin{array}{r}22 \\
1297 \\
175 \\
6160 \\
28535\end{array}$ & $\begin{array}{r}5 \\
1842 \\
200 \\
3488 \\
9210\end{array}$ & $\begin{array}{l}1 \\
200 \\
200 \\
200 \\
200\end{array}$ & $\begin{array}{r}25 \\
7868 \\
500 \\
32252 \\
196693\end{array}$ \\
\hline
\end{tabular}


OBJECTS OF EXPENDITURES

STAFF

DEVELOP-

PLACEMENT

TRANSPORT-
ATION ADMINI-
ATION STRATION

\section{MENT}

$\begin{array}{ll}1 & 107 \\ 2 & \\ 3 & 5 \\ 4 & 37 \\ 5 & 298 \\ 6 & 159 \\ 7 & 289 \\ 8 & 1728\end{array}$

2500

3798

15978

28975

17220
23673

4958

16256

4406

3163

25800

10148

19811

31145

68326

13275

29103
13761

19258

12905

29080

23102

10600

4608

12267

44336

45887

24075

87096

14640

4220

597

42086

25774

15447

45944

46462
31591

28215

67753

178130

180940

27170

35256

99268

99522

8277
3360
25759
9738
1000
29250
4959
10410
4319
5336
10577

7885

38754
5787
6435
1000
12770
13500
5500
10250
500
6010
2192

5
5
13921
8040
1364
32811
3955
33500
7560
2510
20366
8448
47132
34724
36741
10790
38256
33207
76676
1000
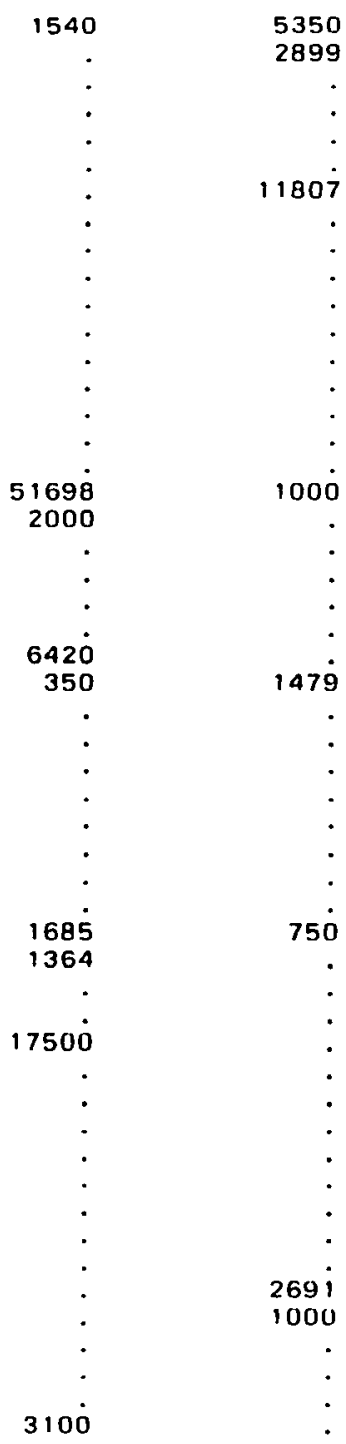

106

$3590^{\circ}$

9647

9641

$5000^{\circ} \quad 449$

5597

$236 \dot{4}$

3337

3246

2173

2787

2885

1334

$1996 i$

9517

$10000^{\circ}$

4548 
OBJECTS OF EXPENDITURES

COUNSELING

STAFF

DEVELOP-

PLACEMENT

TRANSPORTATION

ADMINI -

STRATION

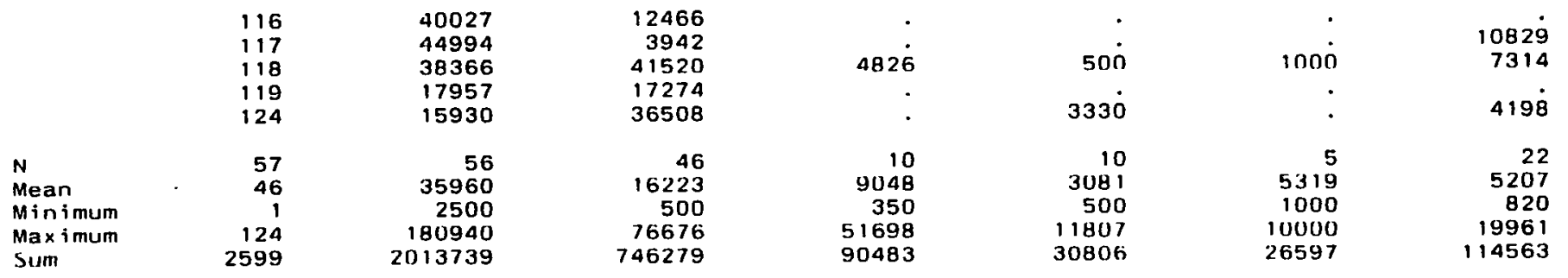


SUMMARY STATISTICS

EXPENDITURES

BY TYPE OF DISTRICT

\begin{tabular}{|c|c|c|c|c|c|c|c|}
\hline CODEX & $\begin{array}{r}\text { TOTS BAS } \\
\text { SKLS/SP } \\
\text { INS }\end{array}$ & $\begin{array}{r}\text { TOT\$ } \\
\text { GUID/COU } \\
\text { NSEL }\end{array}$ & $\begin{array}{l}\text { TOT\$ } \\
\text { STAFF } \\
\text { DEVEL }\end{array}$ & $\begin{array}{r}\text { TOT\$ } \\
\text { PLCMT } \\
\text { SVCS }\end{array}$ & $\begin{array}{r}\text { TOT\$ } \\
\text { TRANS } \\
\text { SER }\end{array}$ & $\begin{array}{l}\text { TOTS } \\
\text { ADMIN }\end{array}$ & $\begin{array}{r}\text { OBJ OF } \\
\text { EXPENDITURES }\end{array}$ \\
\hline \multicolumn{8}{|c|}{1} \\
\hline & 10769 & 8277 & 1540 & 5.350 & . & 1781 & 27717.00 \\
\hline & 2500 & 3360 & & 2899 & . & 1061 & 9820.00 \\
\hline & 50000 & 25759 & . & . & . & & 75759.00 \\
\hline & 37958 & 9738 & . & . & . & 3590 & 51286.00 \\
\hline & 29897 & 1000 & : & . & . & & 30897.00 \\
\hline & 15978 & 29250 & . & 20 & . & . & 45228.00 \\
\hline & 28975 & 4959 & . & 11807 & . & . & 45741.00 \\
\hline & 17220 & 10410 & . & . & . & . & 27630.00 \\
\hline & 23673 & 4319 & . & . & . & . & 27992.00 \\
\hline & 4958 & 5336 & . & . & . & & 10294.00 \\
\hline & 16256 & 10577 & . & . & . & 9647 & 36480.00 \\
\hline & 44061 & . & : & : & . & & 44061.00 \\
\hline & 31632 & & 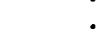 & . & . & . & 31632.00 \\
\hline & 25800 & 7885 & - & . & . & . & 33685.00 \\
\hline & 10148 & & . & . & . & 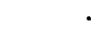 & 10148.00 \\
\hline & 19811 & & . & . & . & . & 19811.00 \\
\hline & 31145 & 38754 & & & 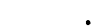 & & 69899.00 \\
\hline & 68326 & 5787 & 51698 & 1000 & & $984 i$ & 136652.00 \\
\hline & 20838 & 6435 & 2000 & . & 5000 & 4492 & 38765.00 \\
\hline & 13275 & 1000 & . & . & . & . & 14275.00 \\
\hline & 29103 & 12770 & . & . & . & . & 41873.00 \\
\hline & 13761 & 13500 & . & . & . & . & 27261.00 \\
\hline & 19258 & 5500 & & . & & . & 24758.00 \\
\hline & 12905 & 10250 & 6420 & 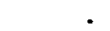 & 5597 & & 35172.00 \\
\hline & 29080 & 500 & 350 & 1479 & . & 2364 & 33773.00 \\
\hline & 23102 & 6010 & 年 & . & 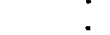 & & 29112.00 \\
\hline & 10600 & 2192 & . & . & . & . & 12792.00 \\
\hline & 6329 & . & . & . & . & . & 6329.00 \\
\hline & 46081 & . & : & : & . & . & 46081.00 \\
\hline & 12267 & . & . & . & . & & 12267.00 \\
\hline & 44336 & & 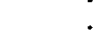 & . & . & 3337 & 47673.00 \\
\hline & 45887 & 13921 & . & . & . & 3246 & 63054.00 \\
\hline & 24075 & & -8 & 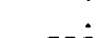 & 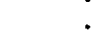 & 2173 & 26248.00 \\
\hline & B7096 & 8040 & 1685 & 750 & . & 5900 & 103471.00 \\
\hline & 14640 & 1364 & 1364 & . & 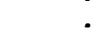 & & 17368.00 \\
\hline & 4220 & 32811 & . & . & . & 2787 & 39818.00 \\
\hline & 6947 & 3955 & & . & & 820 & 11722.00 \\
\hline & 42086 & 33500 & 17500 & . & & & 93086.00 \\
\hline & 25774 & 7560 & & . & $5000^{\circ}$ & $288 \dot{5}$ & 41219.00 \\
\hline & 15447 & 2510 & • & : & & 1334 & 19291.00 \\
\hline & 45944 & & • & 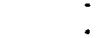 & : & 50. & 45944.00 \\
\hline & 46462 & 20366 & . & . & . & . & 66828.00 \\
\hline & \multirow[t]{2}{*}{31591} & 8448 & • & . & . & & 40039.00 \\
\hline & & 47132 & . & $\cdot$ & . & $1996 i$ & 67093.00 \\
\hline N & 43 & 34 & 8 & 6 & 3 & 16 & 44 \\
\hline & 26517 & 11858 & 10320 & 3881 & 5199 & 4701 & 39546.45 \\
\hline nimum & 2500 & 500 & 350 & 750 & 5000 & 820 & 6329.00 \\
\hline nuin & 87096 & 47132 & 51698 & 11807 & 5597 & 19961 & 136652.00 \\
\hline SumI & 1140211 & 40317 & 82557 & 23285 & 15597 & 75219 & 1740044.00 \\
\hline
\end{tabular}


SUMMARY STATISTICS

BY TYPE OF DISTRICT

\begin{tabular}{|c|c|c|c|c|c|c|c|}
\hline CODEX & $\begin{array}{r}\text { TOTS BAS } \\
\text { SKLS } / \text { SP } \\
\text { INS }\end{array}$ & $\begin{array}{r}\text { TOT\$ } \\
\text { GUID } / \text { COU } \\
\text { NSEL }\end{array}$ & $\begin{array}{l}\text { TOT\$ } \\
\text { STAFF } \\
\text { DEVEL }\end{array}$ & $\begin{array}{r}\text { TOT\$ } \\
\text { PLCMT } \\
\text { SVCS }\end{array}$ & $\begin{array}{r}\text { TOT\$ } \\
\text { TRANS } \\
\text { SER }\end{array}$ & $\begin{array}{r}\text { TOT\$ } \\
\text { ADMIN }\end{array}$ & $\begin{array}{r}\text { OBJ OF } \\
\text { EXPENOITURES }\end{array}$ \\
\hline \multicolumn{8}{|l|}{2} \\
\hline & $\begin{array}{l}28215 \\
67753\end{array}$ & $\begin{array}{l}34724 \\
36749\end{array}$ & : & - & & 9517 & $\begin{array}{r}62939.00 \\
114011.00\end{array}$ \\
\hline & $\begin{array}{r}67153 \\
178130\end{array}$ & $\begin{array}{l}36741 \\
10790\end{array}$ & : & $269 i$ & $10000^{\circ}$ & . & 201611.00 \\
\hline & 180940 & 38256 & . & 1000 & & . & 220196.00 \\
\hline & 27170 & 33207 & . & . & - & . & 60377.00 \\
\hline & 35256 & $\theta^{\circ}$ & . & . & . & & 35256.00 \\
\hline & 99268 & 76676 & & * & . & 4548 & 180492.00 \\
\hline & 99522 & 1000 & 3100 & . & . & 2938 & 106560.00 \\
\hline & 40027 & 12466 & 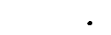 & . & & & 52493.00 \\
\hline & 44994 & 3942 & & & & 10829 & 59765.00 \\
\hline & 38366 & 41520 & 4826 & 500 & 1000 & 7314 & 93526.00 \\
\hline & 17957 & 17274 & . & & & & 35231.00 \\
\hline & 15930 & 36508 & 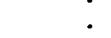 & 3330 & 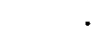 & 4198 & 59966.00 \\
\hline & & & 2 & 4 & 2 & 6 & 13 \\
\hline Mean & 67194 & 28592 & 3963 & 1880 & 5500 & 6557 & 98647.92 \\
\hline in i imum! & 15930 & 1000 & 3100 & 500 & 1000 & 2938 & 35231.00 \\
\hline aximuin & 180940 & 76676 & 4826 & 3330 & 10000 & 10829 & 220196.00 \\
\hline Suin & 873528 & 343104 & 7926 & 7521 & 11000 & 39344 & 1282423.00 \\
\hline
\end{tabular}

